ANA ROBERTA VIEIRA DE ALCÂNTARA

\title{
A internet e o Fórum Social Mundial - a ação política autônoma no mundo das redes
}

\begin{abstract}
Dissertação apresentada ao Programa de Pós-Graduação em Ciência da Informação, Área de Concentração Cultura e Informação, Linha de Pesquisa Mediação e Ação Cultural, da Escola de Comunicações e Artes da Universidade de São Paulo, como exigência parcial para obtenção do Título de Mestre em Ciência da Informação, sob a orientação do Prof. Dr. Martin Grossmann.
\end{abstract}


ANA ROBERTA VIEIRA DE ALCÂNTARA

\title{
A internet e o Fórum Social Mundial - a ação política autônoma no mundo das redes
}

\begin{abstract}
Dissertação apresentada ao Programa de Pós-Graduação em Ciência da Informação, Área de Concentração Cultura e Informação, Linha de Pesquisa Mediação e Ação Cultural, da Escola de Comunicações e Artes da Universidade de São Paulo, como exigência parcial para obtenção do Título de Mestre em Ciência da Informação, sob a orientação do Prof. Dr. Martin Grossmann.
\end{abstract}


AUTORIZO A REPRODUÇÃO E DIVULGAÇÃO TOTAL OU PARCIAL DESTE TRABALHO, POR QUALQUER MEIO CONVENCIONAL OU ELETRÔNICO, PARA FINS DE ESTUDO E PESQUISA, DESDE QUE CITADA A FONTE.

Catalogação na Publicação

SBD - Serviço de Biblioteca e Documentação

Escola de Comunicações e Artes da Universidade de São Paulo

Alcântara, Ana Roberta Vieira de.

A internet e o Fórum Social Mundial - a ação política autônoma no mundo das redes / Ana Roberta Vieira de Alcântara; orientador Martin Grossmann. -- São Paulo, 2009.

$135 \mathrm{f}$. : fig

Dissertação (Mestrado - Programa de Pós-Graduação em Ciência da Informação. Área de Concentração: Cultura e Informação) - Escola de Comunicações e Artes da Universidade de São Paulo.

1. Rede 2. Tecnologia 3. Fórum Social Mundial. I. Título. 


\section{FOLHA DE APROVAÇÃO}

Ana Roberta Vieira de Alcântara

A internet e o Fórum Social Mundial - a ação política autônoma no mundo das redes

Dissertação apresentada à Escola de Comunicações e Artes da Universidade de São Paulo para obtenção do título de Mestre.

Área de Concentração: Cultura e Informação

Aprovada em:

Banca Examinadora

Prof. Dr.

Instituição:

Assinatura:

Prof. Dr.

Instituição:

Assinatura:

Prof. Dr.

Instituição:

Assinatura: 


\section{DEDICATÓRIA}

À Ana Maria e Irineu, meus pais, com admiração e gratidão pelo exemplo, estímulo e incansável apoio.

À Edília e Manoel, meus padrinhos, com quem eu gostaria de comemorar esta conquista.

E a todos aqueles que acreditam na transformação de si mesmos e do mundo. 


\section{AGRADECIMENTOS}

Ao Prof. Dr. Martin Grossmann, pela orientação, pela oportunidade e pela confiança.

À Escola de Comunicações e Artes da Universidade de São Paulo, por todo apoio prestado.

À Coordenação de Aperfeiçoamento de Pessoal de Nível Superior (CAPES), pela concessão da bolsa de mestrado e pelo apoio financeiro para a realização desta pesquisa.

A José Corrêa Leite, pelo valioso apoio, pela generosidade e pela amizade.

A Lucas Bastos Gratz, pelo carinho e pela colaboração na revisão do texto.

Aos amigos que, de alguma forma, contribuíram para a realização deste trabalho, em especial: Daniela Ignácio, Fernanda Reis Guarita e Marcelo Dias Carvalho. 
"O ataque em rede apresenta-se como algo semelhante a um enxame de pássaros ou insetos num filme de terror, uma multidão de atacantes irracionais, desconhecidos, incertos, invisíveis e inesperados. Se analisarmos o interior de uma rede, no entanto, veremos que é efetivamente organizada, racional e criativa. Tem a inteligência do enxame".

Michael Hardt e Antonio Negri 


\title{
RESUMO
}

\author{
ALCÂNTARA, A. R. V. A internet e o Fórum Social Mundial - a ação política \\ autônoma no mundo das redes. 2009. 135 f. Dissertação (Mestrado) - Escola de \\ Comunicações e Artes, Universidade de São Paulo, São Paulo, 2009.
}

A pesquisa investiga as transformações socioculturais atreladas ao desenvolvimento das tecnologias de informação e comunicação e como ocorre a mobilização da sociedade civil global por meio da internet. São analisados aspectos da dinâmica em rede que prevalece nas relações pós-modernas, com destaque para a ação política autônoma de grupos de resistência. O objeto de pesquisa é a relação entre as redes e o Fórum Social Mundial. A metodologia consiste em revisão de literatura em duas frentes principais: referências bibliográficas de caráter multidisciplinar e literatura específica sobre o Fórum Social Mundial. Reportagens, notícias, sites e vídeos também foram consultados, além da participação nos encontros. O trabalho, ao tratar de um objeto contemporâneo em transformação, oferece uma série de reflexões: como potencializar o uso da rede; como a relação com a informação e o conhecimento se altera; como as relações em rede afetam a articulação entre indivíduos e coletivos e a mobilização de movimentos de resistência; como exercer uma participação ativa na esfera pública em rede, contribuindo para uma sociedade mais participativa, livre e democrática.

Palavras-chave: rede; tecnologia; sociedade civil global; esfera pública; Fórum Social Mundial. 


\begin{abstract}
ALCÂNTARA, A. R. V. The internet and the World Social Forum - the autonomous political action in the world of networks. 2009. 135 p. Dissertation (Master) - Escola de Comunicações e Artes, Universidade de São Paulo, São Paulo, 2009.

The research investigates social and cultural changes linked to the development of information and communication technologies and how the mobilisation of global civil society happens throught the internet. Besides, some aspects of the network dynamic that prevail in post-modern relationships are analised, with emphasis on the autonomous political action of resistance groups. The main theme of this research is the relationship between the networks and the World Social Forum. The methodology consists in literature revision on two main fields: multi-disciplinary references and specific literature about the World Social Forum. Articles, news, websites and videos were also sources of information, besides the researcher's participation in the events. The research, when working with a contemporary changing subject, raises a number of issues: how is it possible to maximize the use of network?; how does the relationship with information and knowledge change?; how do the networked relationships affect the articulation between individuals and groups and the mobilisation of resistance movements?; how can individuals participate actively in the networked public sphere to contribute to a more participatory, free and democratic society?
\end{abstract}

Keywords: networks; technology; global civil society; public sphere; World Social Forum 


\section{SUMÁRIO}

APRESENTAÇÃo

1. INTRODUÇÃO 13

2. O MUNDO DAS REDES 21

2.1 REVOLUÇÕES TECNOLÓGICAS 21

2.2 A EMERGÊNCIA DA SOCIEDADE CIVIL GLOBAL 35

2.3 O PARADIGMA DA REDE $\quad 41$

3. FÓRUM SOCIAL MUNDIAL 50

3.1 O MOVIMENTO DE RESISTÊNCIA E O SURGIMENTO DA AÇÃO POLÍTICA AUTÔNOMA EM REDE

3.2 O FÓRUM SOCIAL MUNDIAL: ORIGEM, CARACTERÍSTICAS

$\begin{array}{ll}\text { E OBJETIVOS } & 60\end{array}$

3.3 O FÓRUM SOCIAL MUNDIAL E AS REDES

4. CONSIDERAÇÕES FINAIS 85

REFERÊNCIAS BIBLIOGRÁFICAS $\quad 95$

$\begin{array}{ll}\text { ANEXOS } & 99\end{array}$ 


\section{APRESENTAÇÃO}

Em janeiro de 2002, numa viagem pelo Brasil em companhia de uma amiga italiana que visitava o país pela primeira vez, estive em Porto Alegre para participar de um grande encontro internacional que vinha constantemente fazendo parte das matérias de jornais e revistas nacionais e internacionais, chamado Fórum Social Mundial. Naquele momento, era um pouco nebuloso para mim do que se tratava o evento e fui conhecê-lo de perto com o intuito de participar de alguns debates e saber mais sobre quais temas e quais condições eram capazes de provocar o deslocamento e o encontro de tantas pessoas em um determinado momento.

Depois de alguns dias envolvida pelo clima inovador, festivo, esperançoso, único, diverso em suas temáticas e em seus participantes, tive a sensação de compartilhar com os 60 mil presentes inquietações semelhantes: o desejo de buscar formas alternativas e significativas de se viver; a vontade de participar de discussões e conhecer pontos de vista muitas vezes apresentados de forma camuflada ou parcial para a população de um modo geral; a crença e a esperança de que seria possível construir outras relações e, de fato, interferir no rumo do mundo que antes parecia ser um só, fadado cada vez mais a moldar o pensamento e o comportamento humano através da dominação do mercado, da mídia e de outras tantas entidades assombrosas que permeavam os discursos conhecidos e, também, minhas discussões com alguns colegas do curso de Comunicação Social que eu frequentava na época; um mundo que parecia permitir a construção apenas de 
relações individualistas e mercadológicas rumo à destruição do meio ambiente, dos espaços de criatividade e inovação.

Após essa enriquecedora experiência como participante, tive a oportunidade de fazer parte da equipe de organização do encontro ao trabalhar no escritório do Fórum Social Mundial de outubro de 2002 até o final do ano de 2005. Estive presente nos encontros de 2003 (Porto Alegre), 2004 (Mumbai, Índia), 2005 (Porto Alegre) e 2006 (Caracas, Venezuela), além de fóruns regionais em Natal, Belo Horizonte e Quito, Equador.

Em 2006, minha busca por novos caminhos incluía a vontade de voltar a estudar, de pesquisar se aquilo que eu havia sentido e experienciado na prática existia também no plano teórico; se as minhas inquietações faziam parte de uma crise pessoal ou se eram questionamentos presentes também em discussões acadêmicas.

Tendo concluído a graduação em Comunicação Social, eu questionava as mudanças que vinham ocorrendo com a presença cada vez mais forte e abrangente da internet. A observação crucial para o desenvolvimento dessa pesquisa foi em relação à forma organizativa do Fórum Social Mundial: em rede, informando seus participantes e se comunicando com os envolvidos principalmente via internet. Partindo desse ponto, algumas questões foram levantadas e ajudaram a circunscrever o objeto da dissertação, tais como: qual o papel da internet na mobilização de organizações e indivíduos de diversas partes do mundo que se encontram para uma ação comum em determinado local? Qual o contexto do surgimento do Fórum Social Mundial? Quais transformações decorrentes das relações sociais mediadas por redes podemos observar no que se refere à comunicação, à troca e ao acesso de informação e conhecimento num contexto 
global? Qual a relação do Fórum Social Mundial e de grupos de ação política autônoma com o paradigma da rede?

Ao participar de uma oficina de podcast (programa de áudio publicado na internet), de uma oficina de wiki (edição colaborativa de conteúdos na web), ao tomar conhecimento de diversos sites que ofereciam opiniões e textos totalmente diferentes do que se podia encontrar nos jornais, revistas e programas de televisão habituais, questionei em que aspectos essa mudança tecnológica estava atrelada às transformações socioculturais. Qual o significado de poder produzir, trocar e acessar informações e conhecimento através desse novo tipo de relação? Seria o início de uma época mais participativa, mais consciente e, portanto, mais democrática? Esse conjunto de transformações abriria espaço para práticas individuais e coletivas mais autônomas e, em última instância, permitiria mais empoderamento e emancipação? Ou essa visão otimista seria ingênua, uma mera ilusão? Essas foram algumas questões que também nortearam o presente trabalho.

A forma de organização do Fórum Social Mundial (em rede), sua proposta inovadora, baseada no caráter horizontal, capilar, aberto para múltiplas possibilidades converge justamente com a configuração de rede em que vivemos hoje e com as novas formas de articulação e mobilização que presenciamos no mundo chamado pós-moderno, caracterizado por ações fluidas, desterritorializadas, sem um centro emanador de poder.

A área Cultura e Informação atende às necessidades da pesquisa uma vez que aborda as questões relativas à Sociedade da Informação, ao contexto cultural contemporâneo, às transformações socioculturais do mundo moderno para o pósmoderno e as discussões sobre informação, cultura, novas mídias; produção, distribuição e uso da informação. O caráter multidisciplinar da área é coerente com a 
natureza da temática pesquisada e dos autores escolhidos para formar a base conceitual do trabalho.

Para finalizar, ao nos questionarmos sobre se as relações sociais mediadas por redes revelam uma maior participação e democratização da sociedade ou simplesmente reforçam uma lógica de dominação e controle, observamos que diversas ações autônomas e o próprio o Fórum Social Mundial são expressões do formato em rede que favorecem a convergência, a mobilização e a articulação de milhares de pessoas e grupos e suas práticas de troca de informação, compartilhamento de conhecimento, organização de ações comuns em busca de modos alternativos de se relacionar e novas formas de se viver e de ver o mundo. Um exemplo das transformações socioculturais atreladas a inovações tecnológicas e, também, de como a rede pode fortalecer a comunicação, a troca e uma participação mais efetiva em debates e questões centrais na cultura contemporânea. Essas são algumas reflexões que estarão presentes na pesquisa, que procurou unir elementos da experiência prática com o debate teórico atual.

Ana Roberta V. de Alcântara

São Paulo, 2009. 



\section{INTRODUÇÃO}

O século XIX, período em que ocorreu a Revolução Industrial, foi marcado por grandes inovações tecnológicas: a máquina, o gás de carvão para iluminação e aquecimento e o automóvel. Em outros campos, destacam-se as transformações arquitetônicas tanto em termos de forma como de material utilizado e as vanguardas artísticas do início do século XX.

Esse período de ruptura, denominado modernidade, foi delineado por intensas transformações no modo de produção e nas condições de vida da sociedade. O desenvolvimento tecnológico se acelerou no decorrer do período moderno e se constituiu basicamente em torno do desenvolvimento de máquinas cada vez mais produtivas, que demandavam sucessivas mudanças de matrizes energéticas. Estas mudanças incentivaram ciclos longos expansivos do capitalismo, seguidos de fases depressivas longas: máquinas hidráulicas entre 1780-1815, motor a vapor tendo como combustível o carvão entre 1848-1873, eletricidade entre 1895-1918 (inicialmente de hidroelétricas e depois de termoelétricas), motor a combustão interna tendo o petróleo como combustível entre 1945-1973. (FREEMAN; LOUÇÃ, 2001). Somente a informática, responsável pela onda expansiva iniciada em 1994 e ainda em curso, quebrou este padrão; diferente das inovações anteriores, ela não alterou a matriz energética e de transportes planetária, cuja demanda por combustíveis fósseis segue crescendo.

A modernidade teve como base de sustentação um modelo de civilização ocidental calcado na ideia de crescimento e progressão linear. A sociedade moderna era fortemente sustentada pelas instituições (Estado, Igreja, família, escola, fábrica) 
que estabeleciam as normas sociais e, dessa forma, moldavam e estruturavam a vida. O desencanto com esse ideal de progresso confirmou a falência desse modelo que é, em certa medida, também a falência da crença no maquinismo, na religião, na ideologia e no Estado.

A partir de meados do século $X X$, há uma nova ruptura, dessa vez caracterizada pela mudança das relações de produção industriais para as pósindustriais, relações que passaram a ser baseadas na produção em massa, na eletrônica e nos serviços e trocas de bens simbólicos, como a informação. Essas mudanças contribuem para a formação de um momento histórico chamado, por alguns, de pós-modernidade ${ }^{1}$, por outros entendido como uma nova fase da modernidade. Esse novo período manifesta-se, por exemplo, na relação dos indivíduos com a ideia de tempo. Enquanto a modernidade baseia-se na ideia de um projeto futuro e concebe a história como algo linear, "a pós-modernidade marca-se por uma atenção maior para com o presente e um desejo de viver intensamente o momento agora e aqui”, o presenteísmo (COELHO, 2004, p. 310). A concepção de identidade também sofre alterações, passando de um desejo moderno de homogeneizar o mundo em busca de identidades fixas para a aceitação pósmoderna da diferença, de identidades temporárias, dinâmicas. Outro traço é o questionamento da representação, que muda a forma de participação, uma vez que os indivíduos já não querem ser representados, privilegiando a ação direta. A luta contra o autoritarismo e o paternalismo, que se inicia com os movimentos atuantes na décade de 60 é mais um aspecto que pode ser destacado.

\footnotetext{
${ }^{1}$ Há diferentes opiniões a respeito do início da pós-modernidade, como expõe Teixeira Coelho em Moderno pós moderno: modos \&versões (2005). Optou-se por adotar aqui a associação feita entre as relações pós-industriais e o período pós-moderno. Segundo essa visão, a pós-modernidade teria se manifestado após a Segunda Guerra Mundial.
} 
$\mathrm{Na}$ visão do sociólogo polonês Zygmunt Bauman, estamos em um outro estágio da era moderna. Vivemos na fase da "modernidade líquida", que é "fluida", "leve", do "capitalismo de software". Esses termos são empregados devido à característica dos fluidos (não se atêm muito à forma; estão prontos a mudá-la; não fixam espaço; o que conta é o tempo) em comparação com a característica sólida da modernidade. Na opinião do autor, muitos estudiosos falam em pós-modernidade ou desenvolvem ideias em torno de uma mudança radical no convívio humano porque "o longo esforço para acelerar a velocidade do movimento chegou a seu 'limite natural'. O poder pode se mover com a velocidade do sinal eletrônico [...] e se tornou verdadeiramente extraterritorial, não mais limitado [...] pela resistência do espaço". (BAUMAN, 2001, p. 18, grifo do autor). O autor observa que hoje leveza e mobilidade são as principais bases da dominação e fator das divisões sociais.

Bauman descreve de maneira elaborada e abrangente as sucessivas transformações que esse novo período imprime na condição humana. Ao tratar do conceito de tempo, ele avalia que a instantaneidade característica da modernidade líquida pode trazer, por um lado, a sensação agradável de realização imediata, mas por outro lado, provoca no ser humano a exaustão e o desaparecimento do interesse.

Segundo sua análise, vivemos em um mundo de possibilidades infinitas que gera a sensação de poder se tornar qualquer um. Entretanto, esse estado constantemente incompleto, de oportunidades intermináveis e fluidas, provoca sentimentos de ansiedade e infelicidade.

Outra reflexão que ele desenvolve refere-se à mescla do público e do privado, ou seja, a ocupação da esfera pública por questões antes consideradas de caráter 
privado; há uma redefinição da esfera pública, onde dramas privados são expostos publicamente.

Ainda segundo o autor, na sociedade de consumo em que vivemos, todas as atividades humanas seguem o padrão do consumo, seja de bens materiais seja de conselhos ou receitas de vida. Os espaços frequentados são voltados para o consumo e desestimulam a interação com o outro e o encontro com o diferente. (BAUMAN, 2001).

Embora apresente uma análise bastante interessante e pertinente sobre os efeitos dessa época de transição na condição humana e ofereça elementos que nos possibilitem compreender melhor o mundo, Bauman desconsidera os novos tipos de ação que se destacam por se opor a diversos padrões de comportamento atuais e por buscar formas diferentes e alternativas de se viver.

Se, por um lado, somos acometidos por sentimentos de ansiedade, fragmentação e desamparo frente à perda de um referencial único, imóvel e unidirecional, por outro lado, essas transformações podem gerar novas formas de socialização do conhecimento e da informação, permitindo a participação ativa dos indivíduos no processo cultural. A comunicação entre indivíduos geograficamente distantes, a troca de experiências e a possibilidade de formação de redes internacionais com finalidades semelhantes podem, através do fortalecimento da sociedade civil global, vir a exercer pressão rumo a transformações sociais em nível mundial.

Com o surgimento da internet e da comunicação em rede por ela sustentada, as relações de produção, circulação e acesso à informação são transformadas. Pode-se afirmar que o indivíduo tem a possibilidade de exercer um papel mais 
autônomo e participativo na sociedade mas, simultaneamente, o poder e o mercado também se apoderam desta nova configuração para fortalecer a lógica de controle e dominação.

Nesse cenário de nova ordem global, do chamado "Império" (HARDT; NEGRI, 2005a), onde a soberania compõe-se de organismos nacionais e supranacionais, unidos por uma lógica única que abarca todos os campos da vida, surge o Fórum Social Mundial $^{2}$, encontro anual que une grande parte do movimento global em busca de formas alternativas de se viver e atuar no mundo hoje. O encontro, capaz de reunir milhares de pessoas do mundo todo, entre indivíduos e membros de entidades como organizações não governamentais, movimentos sociais, redes, etc, informa seus participantes e possibilita a comunicação entre diversas organizações, assim como a definição dos eixos temáticos do evento fundamentalmente via internet.

É no contexto da comunicação via internet e das relações em rede que encontros como esse são organizados. Essa transformação para o modelo paradigmático em rede favorece a mobilização e a articulação de pessoas e grupos em atividades de expressão da resistência, permite o encontro, o intercâmbio de conhecimento e a busca por formas alternativas de atuação na sociedade em nível global. O Fórum Social Mundial

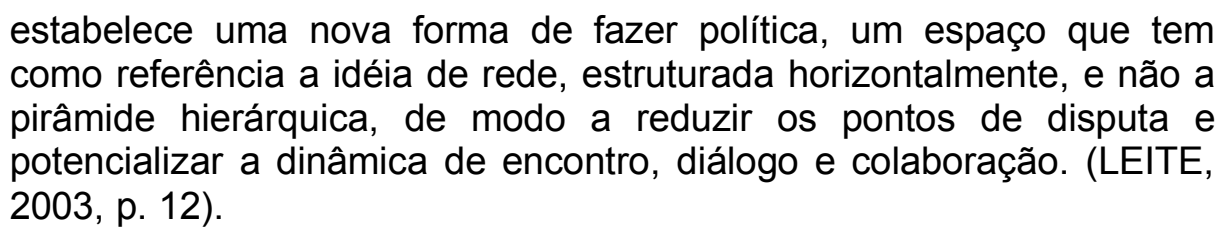

${ }^{2}$ Site: http://www.forumsocialmundial.org.br/ 
A presente pesquisa trata da interação entre o mundo das redes e o Fórum Social Mundial. Para tal, foi feita uma revisão de literatura de caráter multidisciplinar que ajudou a formar o quadro teórico de referência e uma pesquisa bibliográfica especificamente sobre o Fórum. Além disso, diversas revistas, sites e vídeos foram consultados. Finalmente, a presença da pesquisadora nos eventos também foi um elemento que contribuiu para o resultado da pesquisa.

A estrutura do trabalho se dará da seguinte maneira:

O capítulo O mundo das redes apresenta o panorama do mundo de relações em rede em que vivemos atualmente e as intensas transformações socioculturais que vêm ocorrendo em nível mundial paralelamente às inovações tecnológicas das últimas décadas, com destaque para o desenvolvimento das tecnologias de informação e comunicação. O capítulo se inicia abordando brevemente a transformação da relação do ser humano com o conhecimento. A seguir, há um histórico sobre as ondas de inovação tecnológica desde o período industrial até o período atual, revelando qual a novidade e o caráter ímpar da revolução tecnológica que presenciamos hoje. São mostrados alguns exemplos de mudanças em diversas áreas do conhecimento e são apontadas - através da visão de diferentes autores as principais questões do debate contemporâneo a respeito da atuação do homem e suas práticas sociais mediadas pela tecnologia. Num segundo momento, o capítulo aborda a questão da emergência da chamada sociedade civil global, revelando o contexto de seu aparecimento e possíveis definições do termo, além de uma relação com a ideia de esfera pública. Em seguida, é exposto o tema da rede, mostrando aspectos desde o surgimento do termo até sua inserção na sociedade como modelo paradigmático. A discussão a respeito das relações sociais mediadas por redes é feita através de autores que debatem se a internet propicia ou não uma maior 
democracia, se a relação em rede viabiliza uma maior participação cidadã, se as novas formas de comunicação e relação com a informação possibilitam uma maior emancipação e de que forma seria possível construir uma esfera pública com esses valores prevalecendo, ou seja, uma sociedade com mais liberdade, acesso à informação e ao conhecimento e participação ativa.

O capítulo três, Fórum Social Mundial, recupera alguns elementos importantes do contexto sociopolítico mundial das últimas décadas do século $X X$ para pontuar as mudanças constituintes do mundo regido pela dinâmica da globalização e suas consequências na sociedade. A partir do final dos anos 90 começam a surgir movimentos dissonantes que revelam as contradições do processo de reorganização que vinha sendo implantado nas sociedades. A forma de ativismo passa a ser horizontal, capilar, autônoma no lugar dos modelos centralizados e verticalizados predominantes até então. A configuração da ação política autônoma no mundo das redes pode ser observada através da inauguração de uma série de protestos no final do século $X X$ e início do século $X X I$. O Fórum Social Mundial, por sua vez, incorpora e une essas expressões pela primeira vez em 2001. No decorrer do capítulo, é feita uma análise do surgimento do Fórum Social Mundial e das mudanças observadas em cada edição do encontro; são destacados alguns aspectos do processo Fórum e é exposta a visão de alguns autores em relação ao papel e significado do Fórum Social Mundial. Finalmente, desenvolve-se uma relação entre os princípios da ideia de rede e o Fórum Social Mundial e como esta dinâmica pode ser entendida. É importante ressaltar que não se pretende fazer uma avaliação crítica dos pormenores do Fórum Social Mundial e, sim, estudar a relação entre as redes e o Fórum. Por essa razão, alguns elementos críticos em 
relação a sua dinâmica podem estar presentes ao longo do trabalho, mas eles não serão desenvolvidos de forma aprofundada.

Por último, nas Considerações Finais, mais do que apresentar resultados, o objetivo é levantar novos questionamentos e reflexões sobre o tema. Alguns pontos são retomados sinteticamente com o intuito de provocar o leitor a repensar as ideias que foram desenvolvidas ao longo do trabalho. Além disso, algumas observações desta pesquisadora estão presentes, organizadas segundo o ponto de vista externo, de quem participou nos encontros e interno, de acordo com a experiência de trabalho na equipe de organização do Fórum Social Mundial.

Concluindo, o item Anexos disponibiliza material complementar, sendo constituído tanto por documentos sobre o Fórum Social Mundial (Carta de Princípios, Composição do Conselho Internacional), quanto por notícias relacionadas à temática discutida no trabalho e fotos ilustrativas. 


\section{O MUNDO DAS REDES}

\subsection{REVOLUÇÕES TECNOLÓGICAS}

A história do conhecimento passou por distintas fases desde a Antiguidade até os dias atuais. Como podemos lembrar, nos tempos antigos a evidência era para a oralidade como forma de receber e passar adiante o conhecimento. Com a dificuldade inicial do suporte técnico, os livros eram manuscritos e, consequentemente, pouco acessíveis e a existência de alguns leitores propiciava a disseminação da informação através da leitura em voz alta para um grupo de pessoas. Na Idade Média, a leitura começa a ser silenciosa, modificando a forma como o ser humano sistematiza o conhecimento; este aos poucos se desloca da audição para a visualidade. Ao longo do tempo, algumas mudanças culturais em relação à escrita facilitam o trabalho dos copistas gerando uma quantidade cada vez maior de livros encomendados o que, finalmente, culmina na invenção da imprensa, no século XV (informação verbal). ${ }^{3}$ Essa inovação tecnológica transforma o modo como a informação e o conhecimento circulam na sociedade, gerando uma cultura letrada, que é característica constituinte da modernidade.

A sociedade moderna abandonou o argumento sustentador da Idade Média, a fé, para basear-se na razão. Esperava-se, através da união da razão com a técnica, obter-se a emancipação; acreditava-se que o modelo capitalista e a organização industrial da produção ofereceriam tudo para todos. A estrutura montada contava com o suporte das instituições - Estado, Igreja, trabalho, escola, família -

\footnotetext{
${ }^{3}$ Informação fornecida por Giulia Crippa no curso Sociedade, Conhecimento e Informação, ministrado na Escola de Comunicações e Artes da Universidade de São Paulo (ECA, USP), em 2006.
} 
organizadas de modo a controlar e regular o funcionamento da sociedade como um todo.

A modernidade, com suas grandes narrativas de história, progresso, razão, ciência e industrialismo, só se efetiva em sua forma e consciência (liberdade sob orientação da razão), segundo Krishan Kumar, com o marco da Revolução Francesa e, em termos materiais, com a Revolução Industrial. O autor liga a modernidade ao industrialismo, afirmando que este possibilitou que a sociedade ocidental se tornasse uma civilização mundial. "É difícil saber [...] se, sem a tecnologia industrial, a 'superioridade' do Ocidente sobre todos os demais países teria se tornado tão manifesta" (KUMAR, 1992, p. 94). O autor ressalta que ser uma sociedade moderna significava ser uma sociedade industrial. A condição industrializada era vista como salvação da humanidade.

Existem estudos que trabalham com a associação entre "vagas de inovação" tecnológica (as chamadas "revoluções industriais") e ciclos de acumulação capitalista (as "ondas longas"), como a obra de Freeman e Louçã ${ }^{4}$, que defende que estamos vivenciando atualmente a quinta vaga de inovações técnicas.

Estas grandes vagas de inovação tecnológica sempre estiveram ligadas aos ciclos mais amplos de acumulação [...] $\mathrm{Na}$ verdade, os períodos de expansão capitalista são viabilizados pela difusão, pelo tecido social, das inovações de alguns ramos dinâmicos, processo sobre o qual incidem diferentes fatores econômicos e políticos. (LEITE, 2007a, p.1).

Iniciada na Inglaterra, a Revolução Industrial contava com a mecanização hidráulica da indústria têxtil, tendo o tear como principal inovação desta primeira vaga de inovações tecnológicas, cuja fase expansiva foi de 1780 a 1815 . Em sua fase depressiva, de 1815 a 1848 surgiram inovações ligadas à mecanização da

\footnotetext{
${ }^{4}$ As time goes by: the information revolution and the industrial revolutions in historical perspective, 2001.
} 
indústria e do transporte com motor a vapor, sendo a locomotiva e o navio a vapor os principais exemplos da segunda vaga. A terceira vaga (fase expansiva: 1895-1918) foi um período bastante intenso, difundindo diversas inovações, tais como: eletrificação da indústria, dos transportes e das casas; desenvolvimento da siderurgia e química pesadas; produtos de aço amplamente utilizados. Após sua fase depressiva (1918-1940) pode-se observar a motorização generalizada do transporte, da economia civil e da guerra (carros, tratores, aviões). O destaque é para o uso dos motores à combustão interna, que servirá de base à economia do petróleo e também para a difusão dos bens de consumo duráveis, principalmente eletrodomésticos. Sua fase expansiva apresenta indústrias organizadas segundo o modelo fordista e uma característica mais democrática, com o estado do bem-estar social no centro. Após sua fase depressiva (1973) a economia capitalista mundial entra em recessão e os setores do capital procuram solucioná-la impulsionando a globalização neoliberal. Finalmente, a partir de 1994 surgem as inovações ligadas às tecnologias da informação e comunicação, que se difundem e alimentam a expansão das economias centrais.

Segundo análise feita por José Corrêa Leite, o que diferencia a revolução das tecnologias da informação e comunicação das revoluções anteriores é uma das duas dimensões que ela apresenta. A primeira, que a iguala como uma revolução industrial, refere-se ao "estabelecimento de uma infra-estrutura de informação e comunicação", ou seja, cria novos setores produtivos e aparelhos digitais, além de demandar uma nova infra-estrutura de comunicações. Os estudos que nomeiam este período de "Terceira Revolução Industrial" - tendo ocorrido, de acordo com essa visão, a primeira revolução em aproximadamente 1770 e a segunda por volta 
de 1870 -, costumam considerar apenas este aspecto da atual vaga. Entretanto, uma segunda dimensão é ligada

ao uso desta infra-estrutura na produção e distribuição do conhecimento pela sociedade (informação, ciência, arte, cultura). E aqui temos uma ruptura de qualidade com as revoluções anteriores, já que o conhecimento passa a ser o insumo central de boa parte da dinâmica social [...]. De fato, a dimensão industrial é a menos decisiva. Porque os computadores são máquinas universais de processamento de informações, ampliando enormemente a capacidade humana de operar com estas informações (GUEDES; LEITE, 2007, p. 6)

Muitos estudos apontam o período que abrange desde o final do século XX até os dias de hoje como um momento histórico bastante marcante, caracterizado por intensas transformações e uma ruptura rumo a um novo paradigma. O sociólogo espanhol Manuel Castells, em sua conhecida trilogia" ${ }^{5}$, defende que esse é "um evento histórico da mesma importância da Revolução Industrial do século XVIII, induzindo um padrão de descontinuidade nas bases materiais da economia, sociedade e cultura". (CASTELLS, 1999, p. 68). Para o autor, estamos presenciando um processo inédito na história, onde "a mente humana é uma força direta de produção, não apenas um elemento decisivo no sistema produtivo" e, dessa forma,

computadores, sistemas de comunicação, decodificação e programação genética são todos amplificadores e extensões da mente humana. O que pensamos e como pensamos é expresso em bens, serviços, produção material e intelectual, sejam alimentos, moradia, sistemas de transporte e comunicação, mísseis, saúde, educação ou imagens. (CASTELLS, 1999, p. 69).

No volume I da trilogia escrita por Castells, o autor desenvolve detalhadamente suas ideias em torno dessa mudança para um novo paradigma, descrevendo de modo bastante interessante e completo o histórico das tecnologias de informação e comunicação. Aqui, apresentaremos apenas alguns pontos a título de referência do processo histórico.

\footnotetext{
${ }^{5}$ A era da informação: economia, sociedade e cultura, 1999.
} 
O processo de revolução da tecnologia da informação teve início durante a Segunda Guerra Mundial e no período subsequente, com as principais descobertas tecnológicas em eletrônica como, por exemplo, a invenção do transistor, em 1947, que permitiu decodificar a lógica e a comunicação com e entre as máquinas. Dez anos mais tarde, o circuito integrado foi inventado provocando uma explosão tecnológica, já que a tecnologia de fabricação dos materiais foi aprimorada, ocasionando aumento significativo da produção e queda de preço. Em 1971, o microprocessador foi inventado; com capacidade de incluir um computador em um chip, essa invenção causou grande impacto na história da revolução da tecnologia da informação. Com relação aos computadores, como se sabe, o primeiro computador para uso geral surgiu em 1946, na universidade da Pensilvânia, nos EUA, com o apoio do exército norte-americano. A máquina era extremamente grande, pesada e consumia uma quantidade enorme de energia. Essa invenção foi aprimorada, resultando em diversas versões de computadores lançadas ao longo dos anos, destacando-se: a da Apple Computers (1976), seguida pela da IBM, com o conhecido nome de Computador Pessoal (PC) (1981), a do Macintosh (1984), o primeiro a oferecer interfaces e ícones de fácil utilização, entre outras.

A rede que hoje conhecemos como internet teve sua origem por volta de 1960 através do trabalho da Agência de Projetos de Pesquisa Avançada (ARPA) do Departamento de Defesa dos Estados Unidos. Na busca de um sistema de comunicação invulnerável a ataques nucleares, essa Agência criou uma rede independente de centros de comando, que se baseava na tecnologia de comunicação da troca de pacotes, permitindo que a mensagem fosse recuperada em qualquer ponto da rede e não apenas através de um controle central. Em 1969, a primeira rede de computadores - ARPANET - começou a funcionar, aberta aos 
centros de pesquisa que colaboravam com o Departamento de Defesa dos EUA. Em 1983, houve a divisão entre ARPANET, voltada a fins científicos e a MILNET, destinada às aplicações militares. Pode-se concluir que

a criação e o desenvolvimento da Internet nas três últimas décadas do século $X X$ foram conseqüência de uma fusão singular de estratégia militar, grande cooperação científica, iniciativa tecnológica e inovação contracultural. (CASTELLS, 1999, p 82).

Essa fusão fez com que nos anos 90 já fosse possível a comunicação através da rede universal de computadores.

A sociedade passa a se organizar baseada em informação e conhecimento, o que acaba gerando o que muitos chamam de sociedade da informação que, ainda segundo Castells apresenta os seguintes aspectos em sua base material: 1- a informação é sua matéria-prima (são tecnologias para agir sobre a informação, não informação para agir sobre tecnologia como ocorreu nas revoluções tecnológicas anteriores). 2- penetrabilidade dos efeitos das novas tecnologias (informação é parte integral das atividades humanas, então os processos da existência individual e coletiva são moldados pelo novo meio tecnológico). 3- lógica de redes em qualquer sistema ou conjunto de relações, utilizando as tecnologias da informação (configuração de rede pode ser implementada em todos os tipos de processos graças às tecnologias da informação). 4- flexibilidade (capacidade de reconfiguração, um aspecto decisivo em uma sociedade em constante mudança e fluidez organizacional; flexibilidade tanto pode ser uma força libertadora como repressiva, dependendo de quem redefine as regras). 5- convergência de tecnologias específicas para um sistema integrado, no qual trajetórias tecnológicas antigas não se distinguem em separado (microeletrônica, telecomunicações, optoeletrônica e computadores são integrados nos sistemas de informação). (CASTELLS, 1999). 
Hoje, para se ter uma ideia, o Brasil possui por volta de 50 milhões de computadores no ambiente doméstico e corporativo (26 computadores para 100 habitantes). Os números relacionados à participação na rede também são consideráveis e crescem continuamente. Estima-se que em 2009, metade da população (aproximadamente 90 milhões) terá acesso à internet, seja em ambientes de trabalho, domésticos ou públicos. Entre o ano 2000 e meados de 2008 o número de conectados cresceu $900 \%{ }^{6}$

Com a grande capacidade de armazenamento de dados possibilitada pela informática, diversas descobertas científicas são potencializadas e avanços em várias áreas do conhecimento são obtidos com notável velocidade. O efeito mais significativo é que, com a organização de computadores em rede, toda a relação entre homem e conhecimento é modificada, uma vez que informações são produzidas, armazenadas e distribuídas de uma maneira totalmente nova. A princípio, esse aspecto poderia ter um caráter extremamente democrático e emancipatório, possibilitando uma maior participação dos indivíduos em relação à informação e ao conhecimento, através da produção, circulação e acesso a inúmeros bens culturais.

Essas reflexões estão presentes no trabalho de Yochai Benkler, que tem como ponto central de sua análise as relações sociais, operando no terreno da economia. Em seu livro The Wealth of Networks (A Riqueza das Redes), ele concede às tecnologias um papel significativo e afirma que, desde meados do século XIX, a sociedade moderna dependeu, em grande medida, de uma economia informacional industrial para tratar de questões como a produção e o intercâmbio de informação, conhecimento e cultura. Hoje, com a tecnologia, pode-se observar uma

\footnotetext{
${ }^{6}$ Segundo dados fornecidos pela matéria O Brasil cai na rede. Carta Capital, 13 ago. 2008, p. 28.
} 
série de mudanças econômicas, sociais e culturais que possibilitam uma transformação radical no ambiente informacional, questionando como o ser humano se coloca em termos de indivíduo autônomo, cidadão e membro de grupos culturais e sociais. Benkler defende que o modelo econômico vigente na modernidade, que demandava altos custos de investimento para produção de informação, comunicação e cultura (imprensa, telégrafo, rádio, televisão, etc) está cedendo lugar ao que ele chama de "economia informacional em rede", que valoriza a "ação individual descentralizada" (BENKLER, 2006, cap. 1, p. 3), uma ação colaborativa e coordenada através de mecanismos não mercadológicos, não centralizados e independentes de estratégias proprietárias, que depende apenas de um computador individual com acesso à internet em banda larga.

O exemplo mais emblemático do trabalho colaborativo (peer production ou peering) é o software livre, com a criação do sistema operacional Linux, em 1991. Escrito originalmente por Linus Torvalds, um jovem programador do Departamento de Ciência da Computação da Universidade de Helsinque, Finlândia, esse sistema operacional foi licenciado sob uma licença pública geral (GPL), que permitiu a utilização e a participação de diversos outros programadores, que disponibilizaram as alterações realizadas para melhoria do sistema operacional. Até hoje, muitos colaboradores voluntários trabalham para o aprimoramento desse sistema que passou a contar também com a colaboração de grandes empresas.

A Wikipedia é mais um exemplo de produção colaborativa. É uma enciclopédia online, disponível em diversos idiomas e construída por qualquer pessoa que quiser colaborar traduzindo páginas, escrevendo verbetes ou editandoos, contribuindo para que estejam disponíveis gratuitamente na rede mais de um 
milhão de verbetes (versão inglesa), para que ela seja dez vezes maior do que a Enciclopédia Britânica e tenha aproximadamente a mesma precisão. ${ }^{7}$

Atualmente, um fato inédito é que muitas pessoas participam da economia através de novas formas de colaboração em massa, que "estão mudando a maneira como bens e serviços são inventados, produzidos, comercializados e distribuídos globalmente" (TAPSCOTT; WILLIAMS, 2007, p 20).

Esse novo tipo de produção também está sendo adotado como modelo estratégico por grandes empresas. A exemplo disso, pode-se citar a Procter\&Gamble, que permite que cientistas do mundo todo se cadastrem e ajudem a solucionar problemas de pesquisa e desenvolvimento da empresa oferecendo uma recompensa em dinheiro. A produção de reportagens televisivas também pode ser aberta, como mostra uma rede criada quase em sua totalidade por colaboradores amadores, a Current TV, um exemplo entre tantos outros.

O peering consegue obter sucesso porque alavanca a autoorganização - um estilo de produção que funciona com mais eficácia para algumas tarefas do que a gestão hierárquica. O seu maior impacto hoje é na produção de bens de informação - e os seus efeitos iniciais são mais visíveis na produção de software, mídia, entretenimento e cultura - , mas há poucas razões para que o peering pare por aí. (TAPSCOTT; WILLIAMS, 2007, p 37).

As práticas emergentes mostraram-se bem-sucedidas em diversas áreas da sociedade e, juntas, sugeriram "the emergence of a new information environment, one in which individuals are free to take a more active role than was possible in the industrial information economy of the twentieth century". ${ }^{8}$ (BENKLER, 2006, cap. 1, p. 2). Para Benkler, essa nova liberdade carrega promessas que podem ser entendidas na prática como

\footnotetext{
7 Dados fornecidos por TAPSCOTT, Don e WILLIAMS, Anthony D. em Wikinomics: como a colaboração em massa pode mudar seu negócio, 2007.

${ }^{8}$ a emergência de um novo ambiente informacional, no qual indivíduos são livres para assumir um papel mais ativo do que era possível na economia informacional industrial do século XX.
} 
individual freedom; as a platform for better democratic participation; as a medium to foster a more critical and self-reflective culture; and, in an increasingly information-dependent global economy, as a mechanism to achieve improvements in human development everywhere. ${ }^{9}$ (BENKLER, 2006, cap. 1, p. 2).

Benkler defende que as principais diferenças entre a atual "economia informacional em rede" e a era dos meios de comunicação de massa são a arquitetura em rede e a possibilidade de cada um se tornar um porta-voz. Para o autor, essas características modificaram a capacidade de indivíduos - isoladamente ou em grupos - que passaram de leitores e espectadores passivos para uma condição de participantes ativos na esfera pública. Como exemplos da formação de uma plataforma de discussão sobre assuntos de interesse público, ele cita um caso de boicote a um canal televisivo americano envolvido em campanha eleitoral e a emergência da discussão sobre máquinas de votação eletrônica, ambos nos EUA. Para mostrar que estamos diante de uma possível democratização e formação de uma esfera pública em rede, ele levanta uma série de aspectos que defendem o fato de a internet ser um meio democratizador, os quais recuperamos aqui brevemente.

Primeiramente, o autor afirma que, apesar de permitir uma maior participação aos indivíduos, os mecanismos que a internet apresenta para tal são mais complexos do que no passado, daí a dúvida que surge entre muitos estudiosos do assunto sobre se ela seria realmente democratizadora ou não. Em segundo lugar, ele reconhece que sistemas de regime autoritário seguem existindo em diversos locais do mundo e atuando de forma a controlar e censurar o conteúdo disponível na rede e, claramente, não é a internet que possibilitará a democratização desses regimes, mas é possível afirmar que seu caráter dificulta o controle eficaz,

\footnotetext{
9 liberdade individual; uma plataforma para participação democrática mais efetiva; um meio para estimular uma cultura mais crítica e auto-reflexiva; e, em uma economia global crescentemente dependente da informação, um mecanismo para atingir melhorias no desenvolvimento humano em qualquer local.
} 
diferentemente do que ocorre com os meios de comunicação de massa. A título de exemplo, uma matéria publicada no jornal Le Monde em 2008 afirma que o número de chineses que se conectam na Web crescera 56,2\% desde junho de 2007, configurando 253 milhões de chineses conectados, tornando a China o país com o maior número de usuários da internet, segundo estatísticas do China Internet Network Information Centre (CNNIC). A reportagem sublinha a dificuldade que o governo enfrenta para controlar o conteúdo acessado pelos usuários e manter sua política de censura, resultando em um certo enfraquecimento da eficácia da vigilância, apesar de as autoridades ainda contarem com grupos fiscalizadores, como a ciberpolícia. ${ }^{10}$

Finalmente, a internet pode ser entendida como um meio democratizador ao permitir aos indivíduos que experimentem a participação como cidadãos, observando, relatando, questionando e debatendo questões de seu interesse, buscando informações em diversas fontes e difundindo-as da maneira que lhes parecer mais apropriada (através de blogs, listas de discussão, comunidades virtuais, etc), mudando sua relação com a esfera pública.

Com a configuração das relações em rede, novas esferas públicas são criadas e quem deseja participar desses espaços e de discussões de interesse público devem utilizar essas novas tecnologias de comunicação e desenvolver o que Kellner chama de "tecno-política" (KELLNER, p. 3). Ao desenvolver um histórico sobre a categoria de "intelectual" e seu papel na sociedade desde o século XVIII, o autor argumenta que o uso das tecnologias de comunicação é essencial na política contemporânea e o intelectual que deseja intervir nas novas esferas públicas deve levar esse fato em consideração - o autor, inclusive, observa que nunca houve uma autoridades. Le Monde, 30 jul. 2008. 
relação tão próxima entre intelectuais e tecnologia como nos dias atuais. Com o potencial tanto para revigorar práticas democráticas e aumentar a disseminação de pensamentos críticos e ideias progressistas quanto para reforçar as possibilidades de manipulação, controle social e promoção de ideias conservadoras ${ }^{11}$, o ciberespaço requer, reforça o autor, a participação de intelectuais com habilidades para usar essas tecnologias procurando desenvolver estratégias para enfrentar a dominação e promover o empoderamento, a educação, a democracia e outros valores emancipatórios. A ação política e de resistência ocorre em terreno "real", mas mediada pelas tecnologias de informação e comunicação e, dessa forma, devese agir articulando esses dois campos complementares.

Num mundo onde a presença midiática é percebida em todos os campos da sociedade, as intervenções políticas no espaço público pedem a presença da mídia. Como o espaço midiático é moldado pelos setores empresariais e governamentais que estabelecem os parâmetros políticos em relação ao sistema político formal, o surgimento de política insurgente está atrelado à emergência de um novo tipo de espaço midiático: o espaço criado em torno do processo de "mass selfcommunication" (intercomunicação individual), segundo análise elaborada por Castells (CASTELLS, 2007, p. 246). O autor explica que a expressão "mass communication" (comunicação de massa) refere-se ao potencial alcance global através de redes peer to peer e conexão à internet. Já o termo "self" (auto) remetese ao processo comunicativo individual e autônomo de muitos para muitos (produção, emissão e recepção de conteúdo por conta própria). A comunicação baseada na tecnologia de rede, dessa forma, possibilita uma diversidade ilimitada de

\footnotetext{
${ }^{11}$ A agência de notícias Reuters divulgou recentemente o resultado de um relatório que aponta para o crescimento de sites e redes sociais que propagam a violência e comportamentos preconceituosos. Ver ANEXO C.
} 
conteúdo e permite a autonomia dos fluxos de comunicação que constroem continuamente a produção de significado presente nas mentes em âmbito local e global.

O processo de "mass self-communication" apresenta-se como um terreno fértil para a nova atuação de movimentos sociais e indivíduos que buscam construir sua autonomia e confrontar as instituições sociais. Certamente, os movimentos sociais e outros coletivos de resistência que propõem alternativas ao sistema e às instituições vigentes já existiam e atuavam antes da atual revolução tecnológica, mas atualmente o modelo baseado em comunicação em rede é a forma organizacional amplamente adotada por esses grupos, diferentemente das estruturas tradicionais e hierárquicas de partidos políticos, sindicatos, entre outros.

For new social movements, the Internet provides the essential platform for debate, their means of acting on people's mind, and ultimately serves as their most potent political weapon. But social movements do not exist only in the Internet...And when they act, they mobilize in specific places, often mirroring the places of the power institutions, as when they challenge meetings of WTO, the IMF or the G8 group. ${ }^{12}$ (CASTELLS, 2007, p. 250)

O crescimento dos movimentos sociais nos últimos anos - simultâneo ao crescimento da crise da legitimidade política em escala internacional - representa o que o autor denomina de "contrapoder". Como explica,

By counter-power I understand the capacity by social actors to challenge and eventually change the power relations institutionalized in society. In all known societies, counter-power exists under different forms and with variable intensity, as one of the few natural laws of society, verified throughout history, asserts that wherever is

\footnotetext{
${ }^{12}$ Para novos movimentos sociais, a internet oferece a plataforma essencial para debates, o meio pelo qual atingem a mente das pessoas e serve como a arma política mais potente. Mas os movimentos sociais não existem só na internet...E quando eles agem, eles se mobilizam em locais específicos, freqüentemente tendo como alvo locais onde estão as instituições de poder, como quando desafiam as reuniões da OMC, do FMI ou do G-8.
} 
domination, there is resistance to domination, be it political, cultural, economic, psychological, or otherwise. ${ }^{13}$ (CASTELLS, 2007, p. 248)

Talvez, num cenário onde o poder se move com a velocidade do sinal eletrônico, onde ele é extraterritorial, seja mais apropriado falar em antipoder no lugar de contrapoder, uma proposta mais radical cujo objetivo não é a conquista de um poder para substituir outro, mas sua dissolução.

Ao longo de todo o século $X X$, mudar o mundo através do Estado foi 0 paradigma dominante do pensamento de resistência. Somente atuando na esfera estatal, aonde se chegava através da atividade em partidos políticos ou unindo-se a grupos que pretendiam tomar o Estado, era possível mudar o mundo. As relações de poder eram frequentemente reproduzidas, provocando o fracasso de diversas iniciativas.

Atualmente, as expressões que refletem o descontentamento do mundo são mais difusas. Há um vasto campo de atividade onde indivíduos ou grupos procuram agir criticamente e transformar o mundo, mas sem ter como propósito ocupar o Estado ou galgar posições de poder. (HOLLOWAY, 2003).

Diversas intervenções que compõem a resistência na atualidade agem segundo novas dinâmicas, sua ação "não tem o poder por meta, ou seja, a criação de um contrapoder que substitua o poder existente. Visam a criação de um antipoder que anule todas as formas de autoritarismo e ative a participação". (OLIVEIRA, 2007, p. 125).

${ }^{13}$ Entendo que contrapoder é a capacidade dos atores sociais de desafiar e finalmente mudar as relações de poder institucionalizadas na sociedade. Em todas as sociedades conhecidas, o contrapoder existe sob diferentes formas e com intensidade variável, como uma das poucas leis naturais da sociedade, verificada no decorrer da História, assegurando que onde há dominação, há resistência à dominação, seja política, cultural, econômica, psicológica ou outra. 
A questão é como estabelecer este antipoder num mundo onde o poder se tornou nômade, fluido. No estado atual de "modernidade líquida", "leve", do "capitalismo de software", como sustenta Zygmunt Bauman, onde o capitalismo viaja rápido e leve, onde a fluidez é a metáfora adequada para definir o mundo, como entrelaçar as escolhas individuais em projetos coletivos sem que essa ação dependa de um comando centralizado, de uma estrutura hierárquica moderna? $\mathrm{Na}$ modernidade sólida, o capital mantinha-se atrelado ao trabalho, o objetivo supremo dos detentores do poder era a conquista do espaço, a aquisição territorial e a resistência era organizada de forma tão centralizada e hierárquica quanto o trabalho nas fábricas. Com a transformação dessa realidade, como se organiza hoje esse antipoder?

\subsection{A EMERGÊNCIA DA SOCIEDADE CIVIL GLOBAL}

É nesse contexto que observamos a emergência do que alguns teóricos chamam de sociedade civil global. Esse conceito é entendido de forma bastante diferente entre alguns autores, o que ocasiona inúmeras definições sobre o termo. Algumas definições mais conhecidas colocam a sociedade civil como um conjunto de organizações e instituições da sociedade em oposição à estrutura estatal. Entretanto, em cada época surgem novos elementos que formam o contexto histórico, dando origem a novas definições, mais precisas e adequadas de acordo com as circunstâncias.

Primeiramente, a definição proposta por Chico Whitaker será apresentada. Segundo sua concepção, 
sociedade civil são as instituições não-governamentais, as associações, os movimentos e as entidades sindicais, o que corresponde à parte da sociedade que se organiza para realizar determinados objetivos, superando, portanto, a ação individual desligada do conjunto da sociedade. [...] essa compreensão exclui partidos políticos, governos, e suas instituições internacionais, e organizações militares. (WHITAKER, 2005, p. 59)

Ao analisar a relação entre o conceito de sociedade civil e o Fórum Social Mundial, que teve sua primeira edição em 2001, na cidade de Porto Alegre, Brasil, o autor afirma que

até o surgimento do Fórum Social Mundial, a sociedade civil como um todo, em sua multiplicidade e em sua diversidade de organizações, não dispunha de espaços de encontro (de nível local, regional, nacional e até mundial) como é o Fórum. $O$ tecido da sociedade organizada não tinha como emergir do tecido da sociedade nãoorganizada. E é essa articulação de nível planetário que o Fórum tem propiciado que nos permite dizer [...]: "A consciência de cidadania está ainda longe de atingir as grandes maiorias nacionais. Mas ela já ganhou uma dimensão mundial, fazendo nascer um ator verdadeiramente novo na cena internacional: a sociedade civil internacional". (WHITAKER, 2005, p. 60).

Outros autores não consideram pertinente o uso do termo e fazem reservas

quanto à sua utilização. Boaventura S. Santos, renomado intelectual português, expressa essa opinião ao esclarecer que

Não faz sentido hoje falar de sociedade civil global porque não há nenhum mecanismo global que garanta os direitos cívicos dos cidadãos. Mas se se quiser falar de sociedade civil global, então é necessário distinguir entre sociedade civil global liberal, que se alimenta da globalização neoliberal, e sociedade civil global emancipatória, que promove a globalização contra-hegemónica, a globalização solidária de que o Fórum Social Mundial é uma eloqüente expressão. (Santos, 2005, p. 109).

José Corrêa Leite demonstra em sua pesquisa que esse é um conceito bastante questionável. Seu estudo nos mostra que, segundo a acepção de Gramsci,

as organizações privadas que compõem a sociedade civil no terreno nacional - o espaço onde é organizado a hegemonia e o consentimento - apenas se distinguem do estado metodologicamente. Gramsci, ao contrário de Marx, vai enfatizar a inter-relação entre estado e sociedade civil. É, por exemplo, o próprio estado que 
estabelece orientações como a não-intervenção estatal. (LEITE, 2005, p. 377).

Em sua tese, o autor apresenta algumas visões do termo sociedade civil global. Reproduziremos aqui alguns trechos de sua pesquisa a fim de revelar essas diferentes concepções. Inicialmente, o autor nos explica que

O termo sociedade civil global abarca diferentes funções - explicação empírica do que se passa, projetos políticos, avaliações normativas. Mary Kaldor vai localizar cinco concepções de sociedade civil e de sua aplicação no terreno global: a atualização da concepção kantiana de uma ordem cosmopolitana regida pela lei; a projeção da concepção hegeliana e marxista de uma esfera entre a família e o estado onde se faz a história; a esfera pública global, vista pelos ativistas como espaço da cidadania ativa, de radicalização da democracia, da autoorganização e de extensão da participação e da autonomia; a concepção liberal que a enxerga como resultado da privatização do esforço de construção da democracia e de engajamento humanitário, pela caridade, associações voluntárias ou atividade do terceiro setor; e a concepção pós-moderna, que a concebe como palco para todas as redes de contestação. Kaldor enfatiza que todas estas conceituações são normativas e descritivas, todas apreendem aspectos da realidade e todas se confrontam nas práticas que orientam. (LEITE, 2005, p 381).

Ao identificar-se com a definição de sociedade civil como "esfera pública

global", a autora citada

define a sociedade civil global como 'uma esfera de idéias, valores, instituições, organizações, redes e indivíduos localizada entre a família, o estado e o mercado, e operando além dos confins das sociedades, políticas e economias nacionais'. Aí se enfatiza que esta descrição carrega um sentido normativo focado nas formas como a sociedade civil pode influenciar a governança global. (LEITE, 2005, p 382).

Em termos históricos, para Kaldor

o termo sociedade civil emergiu nos anos 1980 para descrever os novos movimentos sociais que foram protagonistas dos processos de democratização em várias partes do mundo, mas depois passaram a remeter a ONGs, de um lado, e a novos movimentos nacionalistas e fundamentalistas, de outro. (LEITE, 2005, p 382).

O autor John Keane oferece uma outra visão sobre a discussão. Em seu trabalho 
ele traça as raízes da sociedade civil global na tradição de hospitalidade das religiões universalistas, em particular do Islã. Ela, todavia, teve seu primeiro florescimento no capitalismo liberal da segunda metade do século XIX, que ele vê perdurando até 1914. Neste período, inúmeras iniciativas cívicas, humanitárias, reformistas e modernizadoras foram tomadas por agentes privados - propriedade intelectual, tráfico de drogas, condições de trabalho, prostituição, acordos estatísticos e científicos, etc [...] Keane constrói seu conceito de sociedade civil global em polêmica com as concepções ativistas, ressaltando que não existe alternativa ao mercado e que não se pode ignorar aspectos positivos no atual processo de globalização - embora se deva combater aspectos negativos como o crescimento das desigualdades...

Keane sintetiza sua concepção em um tipo ideal: 'um sistema nãogovernamental dinâmico de instituições sócio-econômicas interconectadas que cruzam toda a terra... A sociedade civil global não é nem um objeto estático, nem um fait accompli. É um projeto inacabado que consiste de redes, pirâmides e constelações... de instituições sócio-econômicas e atores que se organizam através de fronteiras, com o objetivo expresso de desenhar o mundo de novas formas...' (LEITE, 2005, p 382-383).

Atualmente, o termo sociedade civil global pode abarcar também alguns grupos de resistência à dominação pela globalização e pelo neoliberalismo. Nesse sentido, o uso se dá devido ao caráter inter e transnacional das mobilizações e articulações, intensificado principalmente em meados da década de 90, uma vez que sua atuação vai além de territórios e espaços físicos fixos e determinados.

O papel do território e dos espaços físicos fixos também influencia a concepção de esfera pública, tradicionalmente atrelada à estrutura do Estado-nação moderno. Na modernidade, havia a ideia de construir um espaço político onde os cidadãos pudessem agir e esse espaço estava ligado ao espaço físico ocupado pelo poder do Estado. Nessa época, a ideia de esfera pública ligava-se à luta contra o uso abusivo do poder por monarcas e cortes; era um espaço de discussão dos diversos temas da sociedade e um instrumento da liberdade desejada na época, como a liberdade de imprensa, de participar da elaboração da legislação, etc. A esfera pública burguesa situava-se nos centros urbanos e era composta por cafés e 
bares onde circulava a informação e predominavam as discussões e troca de ideias sobre assuntos de interesse da sociedade.

Historicamente, a ligação dos Estados com a constituição da esfera pública foi perdendo espaço, como descreve John Keane:

O velho domínio da vida pública limitada territorialmente e estruturada
pelo Estado, mediada pelo rádio, televisão, jornais e livros, está
chegando ao fim. Sua hegemonia está sendo rapidamente erodida
pelo desenvolvimento de uma multiplicidade de espaços de redes de
comunicação, as quais não estão ligadas imediatamente a territórios, e
que por conseguinte flanqueiam e fragmentam qualquer coisa que
anteriormente se parecesse com uma esfera pública única e
espacialmente integrada dentro da estrutura Estado-nação. [No lugar
dessa esfera pública unificada, observa-se o] desenvolvimento de um
mosaico complexo de tamanhos diferentes, sobrepondo e
interconectando esferas públicas. (KEANE, 1997, p. 14).

Observa-se, desse modo, que os termos sociedade civil global e esfera pública são interdependentes, ambos tendo passado por consideráveis mudanças estruturais desde a modernidade até os dias atuais. As inovações tecnológicas e a predominância da relação em rede contribuíram para a nova configuração que tem se observado atualmente. Assim, essa esfera pública desterritorializada e conectada é o campo de atuação da chamada sociedade civil global.

Benkler desenvolve o conceito de "esfera pública interconectada", um campo de atuação fruto de práticas sociais atreladas às ferramentas oferecidas pela internet. Segundo essa conceituação, um primeiro efeito na esfera pública pode ser observado no campo da atividade de produção de informação e cultura de atores não mercadológicos emergentes: indivíduos trabalhando sozinhos e em cooperação com outros, um maior número de associações formais como ONGs e o efeito que eles produzem na mídia convencional. Essas mudanças fazem com que a esfera pública interconectada influencie os dois conceitos centrais da mídia de massa: o 
excesso de poder nas mãos dos proprietários e a tendência a estimular uma inércia política.

As práticas sociais ligadas à informação permitem que muitos atores se vejam não mais como receptores passivos, mas como potenciais participantes na construção do discurso público e como potenciais atores em arenas políticas.

De acordo com a análise do autor, a chamada "economia informacional em rede" desenvolveu-se com capacidade para filtrar, sintetizar observações e opiniões de um número de pessoas muito maior do que os meios massivos. Fez isso sem recriar pontos de controle e manipulação que replicariam a limitação central do modelo dos meios de comunicação de massa, sempre suscetíveis ao controle de seus proprietários ou ao domínio mercadológico.

A estrutura de debate e ação coletiva é bastante diferente hoje; não há um poder central orquestrando as ações, mas séries de ações não coordenadas que se reforçam mutuamente realizadas por indivíduos em diferentes situações e contextos.

Segundo Benkler, no ambiente informacional conectado, todos possuem uma verdadeira capacidade de observar, relatar, questionar e debater através de recursos como blogs, listas de discussão, e-mails, comentários em blogs, etc. As novas práticas estão mudando o local da criação de conteúdo, do tradicional jornalista para as mãos de quem realmente constitui a sociedade. $O$ papel do cidadão ideal não é mais ler apenas o que escrevem os formadores de opinião e buscar informações para decidir sobre seu voto e, sim, participar ativamente publicando material, emitindo opinião e debatendo assuntos de interesse público, contribuindo para uma nova configuração da esfera pública.

Em suas palavras, 
We are witnessing a fundamental change in how individuals can interact with their democracy and experience their role as citizens. [...]. They are no longer constrained to occupy the role of mere readers, viewers, and listeners. They can be, instead, participants in a conversation. [...] The network allows all citizens to change their relationship to the public sphere. They no longer need be consumers and passive spectators. They can become creators and primary subjects. (BENKLER, 2006, cap. 7, p. 63) ${ }^{14}$

\subsection{O PARADIGMA DA REDE}

O terreno de atuação da chamada sociedade civil global é a rede, como de todas as demais relações sociais e econômicas da nova ordem mundial, dos serviços aos meios de comunicação, do mercado aos meios de transporte. Na forma de sociedade contemporânea tudo é em rede. Até mesmo o pensar, o espaço, o tempo e a subjetividade são em rede (PARENTE, 2004).

O conceito de "rede" que está presente em nosso imaginário em geral se refere a um processo relativamente recente que envolve, como foi desenvolvido até aqui, o surgimento e a disseminação de tecnologias de informação e comunicação que possibilitaram a configuração comunicacional em que vivemos atualmente. Sem dúvida, foi quando essas tecnologias se tornaram estruturantes nas sociedades do mundo todo que a rede se tornou um novo paradigma global. Entretanto, esse conceito remete-se, no mínimo, à Antiguidade, quando seu emprego estava associado à metáfora de um organismo humano, levando em consideração as veias e os fluidos constantemente entrelaçados e interdependentes. A palavra "rede" só surge na língua francesa no século XII e, apesar de algumas associações com rede

\footnotetext{
${ }^{14}$ Estamos testemunhando uma mudança fundamental no modo como indivíduos interagem com a democracia e experimentam seu papel de cidadãos [...]. Eles já não são coagidos a ocupar o papel de meros leitores, espectadores e ouvintes. Eles podem ser, ao contrário, participantes em uma conversa. [...] A rede permite que todos os cidadãos mudem sua relação com a esfera pública. Eles já não precisam ser consumidores e espectadores passivos. Eles podem se tornar criadores e sujeitos principais.
} 
de caça ou pesca, fios de tecido, cestas, o termo é predominantemente empregado na linguagem médica. É a partir do século XVIII que há uma ruptura e o conceito de rede se exterioriza, passando a ser visto fora do corpo, como uma estrutura a ser formada artificialmente. "A rede não é mais apenas observada sobre ou dentro do corpo humano, ela pode ser construída [...]. De natural, a rede vira artificial". (MUSSO, 2004, p. 20). A rede se torna um modelo de racionalidade na época moderna, operacionalizando a rede de transportes (estradas de ferro) e de comunicações (correio, telefone), provocando uma mudança na relação com o tempo e com o espaço. O trabalho nas indústrias permitia uma aceleração no ritmo de produção, mas era necessário também aumentar a velocidade de distribuição dos produtos, o que pôde ser conseguido através do investimento em uma remodelagem do sistema de transportes.

Pierre Musso reforça a criação de um novo paradigma do raciocínio e afirma que

hoje, o conceito de rede tornou-se uma espécie de chave-mestra ideológica, porque recobre três níveis misturados de significações: em seu ser, ela é uma estrutura composta de elementos em interação; em sua dinâmica, ela é uma estrutura de interconexão instável e transitória; e em sua relação com um sistema complexo, ela é uma estrutura escondida cuja dinâmica supõe-se explicar o funcionamento do sistema visível (MUSSO, 2004, p. 32).

Para além das possíveis definições do termo, o autor observa que a presença da rede revela sempre um caráter oscilante, ora voltado à circulação, ao acesso, à liberdade e ora direcionado à vigilância, à dominação e ao controle. Um outro aspecto apontado a respeito da metáfora da rede é que ela coloca-se constantemente entre a ordem linear, a estrutura e a organização de um lado e a desordem, o caos e o aleatório de outro. 
Para Sergio Amadeu ${ }^{15}$ o debate entre o caráter libertário ou controlador da rede esbarra na questão dos chamados intermediários tecnológicos, dos protocolos e softwares. Como se sabe, para criar a arquitetura básica da internet - uma rede de redes - foram estabelecidos alguns protocolos de comunicação, essenciais para que uma rede de computadores entendesse os dados enviados por outra rede. $\mathrm{O}$ protocolo de controle de transmissão (TCP) foi lançado em Stanford, em 1973, dividido em duas partes: uma encarregada de dividir as informações em pacotes e outra responsável por localizar o endereço de destino dos respectivos pacotes de informação. Essa é a linguagem básica da rede; a linguagem que possibilita a comunicação é composta por protocolos. Vale ressaltar que os protocolos são criados por técnicos, que estabelecem as especificações de cada protocolo, ou seja, o que se pode ou não fazer, quais as regras daquele ambiente ou daquela relação de comunicação. Em decorrência desse fato, o autor aponta três impactos sociais importantes: primeiramente, o fato de que uma constatação aparentemente de ordem técnica esconde questões sociais e políticas sobre em que medida a sociedade está preparada para decidir sobre temas que permitem mais ou menos privacidade, maior ou menor liberdade, muita ou pouca segurança. Em segundo lugar, o autor questiona se, na ausência de entendimento e participação social, a forma atual de decisão é a que melhor assegura a liberdade e a democracia da rede e da comunicação mediada por computador. Finalmente, a terceira questão é como evitar que ditaduras políticas e mega-corporações utilizem sua capacidade técnica e organizacional para exercer domínio sobre os padrões e ditar comportamentos na sociedade em rede. (SILVEIRA, 2005).

\footnotetext{
${ }^{15}$ SILVEIRA, Sergio Amadeu da. A mobilização colaborativa e a teoria da propriedade do bem intangível, 2005.
} 
O autor argumenta que numa sociedade cada vez mais dependente da comunicação mediada por computador, softwares e protocolos ocupam o lugar de intermediários da inteligência humana, pois têm o papel de linguagem não natural, básica e essencial. Além disso, eles podem ser entendidos como as novas legislações, uma vez que desempenham papel de instrumentos de regulação da comunicação. Os softwares podem ser fechados (código-fonte fechado, com um conjunto de regras desconhecido dos usuários) ou abertos (transparência do códigofonte do software) e proprietários (a empresa desenvolvedora define quais ações são ou não permitidas; voltado ao controle do conhecimento) ou não proprietários (reconhecimento de autoria, não da propriedade de ideias; voltado ao compartilhamento de conhecimento). O software livre, por exemplo, é desenvolvido através de um trabalho colaborativo, aberto e não proprietário.

Dessa forma, o modo como os softwares são desenvolvidos provoca um grande impacto social, cultural e político. Uma das questões cruciais da sociedade da informação diz respeito à linguagem que essa sociedade utiliza, que pode ser privada ou pública, fechada ou aberta, hierarquicamente construída ou compartilhada, democrática ou autoritária.

Mas como interferir na sociedade da informação para que ela seja mais democrática? Como permitir uma maior participação dos indivíduos na rede? Como garantir que a informação e o conhecimento estejam disponíveis e possam ser compartilhados? Para Sergio Amadeu (2005), embora as pessoas, de um modo geral, não tenham conhecimento de que os códigos determinam seu grau de liberdade na rede e não sejam capazes de discutir detalhes tecnológicos, elas podem definir como querem que estes códigos, intermediários e linguagens sejam socialmente controlados se tiverem consciência de que a sociedade em rede é 
dependente da tecnologia e se efetiva através destes intermediários da inteligência humana.

Concretamente, significa disseminar a informação de que o espaço virtual exige especialistas que devem defendê-lo como um espaço livre e aberto contra as limitações, bloqueios e violações que podem ser impostas antidemocraticamente por Estados ou corporações. Essa participação corresponderia à formação de uma nova esfera pública na sociedade em rede, lembrando que a esfera pública só apresenta sentido político se nela as pessoas forem capazes de opinar, de posicionarem-se sobre temas do sistema político ou fatos que incidam sobre suas vidas. É necessário defender a transparência dos protocolos, padrões e softwares para que o espaço virtual possa ser considerado um espaço público virtual, essencial à sua consolidação como esfera pública. ${ }^{16}$

A arquitetura da internet, de caráter aberto desde o início, favorece atividades compartilhadas e criativas dos usuários.

Longe do patenteamento e de outros modelos de apropriação privada de idéias, a internet é uma rede em constante evolução. Ela é fundamentalmente inacabada. Suas regras básicas, os protocolos principais, são abertos e desenvolvidos colaborativamente. Seus dois elementos estruturantes, até o momento, foram a reconfiguração constante e a recombinação das tecnologias e dos conteúdos. (PRETTO; SILVEIRA, 2008, p. 35).

O autor cita o movimento do software livre e o "Open Source" (código-fonte aberto) que, baseados em valores de liberdade e colaboração, são mobilizações tecno-políticas que formaram uma rede significativa de colaboração tecnológica, de debate crítico, de solidariedade e articulação de ações em defesa da liberdade do conhecimento; uma rede que produz códigos de modo colaborativo e constitui uma crítica político-cultural ao modelo hegemônico de propriedade do conhecimento.

\footnotetext{
${ }^{16}$ Ibidem.
} 
Segundo sua tese, a nova configuração da sociedade da informação fez com que as diferenças entre esquerda e direita se dissolvessem. Em se tratando da informação, sua característica fundamental é a intangibilidade e a imaterialidade, ou seja, seu uso não a desgasta e sua multiplicação (digital) permite, além de conservar a qualidade, o uso por várias pessoas simultaneamente. Assim, sua qualificação econômica é a de um bem não rival. Dessa forma, o modelo colaborativo é entendido como mais vantajoso tanto para os grupos tradicionalmente conhecidos como de direita - pela redução dos custos de transação, pela maior qualidade de softwares compartilhados e pela forma mais eficiente de produção de riqueza - como de esquerda - que acreditam na possibilidade de o modelo colaborativo em rede gerar mais igualdade, liberdade e solidariedade. (SILVEIRA, 2005)

Colocando a liberdade como principal valor, o autor conclui que o elemento condutor das grandes transformações que podem surgir com o novo modelo de compartilhamento de ideias são as organizações e indivíduos que defendem a liberdade como elemento fundamental para criação, para defesa dos direitos, para geração de valor e para o desenvolvimento econômico. A liberdade do conhecimento permite tanto a formação de uma esfera pública no ciberespaço quanto uma maior igualdade de distribuição de riqueza produzida nessa esfera. ${ }^{17}$

A busca e a construção de uma esfera em rede mais democrática também fazem parte da proposta dos autores de Império e Multidão. Eles apostam no que denominam "projeto da multidão", que revela o desejo de um mundo onde prevaleçam a igualdade e a liberdade e que demanda uma sociedade global democrática que seja aberta e inclusiva. Inicialmente, Antonio Negri e Michael Hardt desenvolvem seu trabalho em torno do que vem se consolidando como uma nova 
ordem global, ou seja, uma nova lógica de comando que regula o mercado global e os circuitos globais de produção, que ignora fronteiras territoriais e recusa-se a estabelecer um centro de comando. A essa nova estrutura que governa o mundo todo, os autores deram o nome de "Império". Nele, a produção de riqueza não se limita ao aspecto econômico, mas abrange o político e o cultural, tornando-se a produção da própria vida social, traduzida como produção biopolítica. A tese defendida esclarece que a globalização possui duas faces: de um lado, encontra-se a face do Império, que espalha sua rede globalmente e mantém a ordem através de novos mecanismos de controle e conflito. Do outro lado, está a multidão, que viabiliza a criação de novos circuitos de cooperação e colaboração em todo o mundo, possibilitando a descoberta de pontos comuns que facilitam a comunicação e a ação conjuntas.

A multidão é uma rede, é um espaço amplo, aberto e em expansão, que permite a expressão das diferenças singulares e oferece meios de convergência para o trabalho e a vida em comum. Não exige fidelidade a um valor único, a uma identidade comum ou a uma figura soberana, mas aceita o conjunto de singularidades que buscam pontos comuns de ação rumo a uma transformação social. Como a própria estrutura da internet e outros organismos em rede, a multidão tem seus vários pontos nodais que, apesar de se manterem diferentes entre si, estão ligados e conectados de uma forma ampla e horizontal, permitindo novos contatos entre os nós a qualquer momento.

Em um histórico sobre as formas de resistência que abordaremos mais adiante, os autores revelam três princípios orientadores dos movimentos de libertação: o primeiro é a oportunidade histórica, que trata da forma de resistência mais eficaz no combate a determinada forma de poder. O segundo é a 
correspondência entre a forma de resistência e as transformações da produção econômica e social, ou seja, em cada época, o modelo de resistência mais eficaz tem a mesma forma que os modelos dominantes. Esse princípio se valida ao observarmos a forma em rede de articulação, mobilização e comunicação existente atualmente. A multidão que atua com o objetivo de criar uma sociedade global alternativa age na mesma rede que o poder exerce seu domínio; a atuação tanto do poder quanto do antipoder é de forma fluida, inconstante, múltipla, extraterritorial. Ambos apostam na ação descentralizada, desterritorializada e em rede. O terceiro princípio refere-se à busca de democracia e liberdade, ressaltando que cada nova forma de resistência tem como objetivo atacar os aspectos antidemocráticos das formas anteriores, formando um encadeamento de movimentos cada vez mais democráticos. Atualmente, critica-se o modelo de estrutura organizacional hierárquica e centralizada dominante na era moderna; a credibilidade nas organizações partidárias e no modelo de representação já não se faz presente.

Negri e Hardt argumentam a favor de duas características da multidão que revelam seu potencial democrático: no âmbito econômico, a produção biopolítica novo modelo dominante que envolve a produção de bens materiais, mas também afeta e produz todas as facetas da vida social, sejam econômicas, sociais ou políticas - e a expansão do comum - ação baseada no ponto comum das singularidades. E no aspecto político - que agora está mesclado nos terrenos econômico, social e cultural - uma tendência da passagem da organização centralizada das resistências modernas para as organizações contemporâneas em rede.

As relações em rede configuram uma nova dinâmica cultural, que exibe novas formas de associação, de coabitação, marcadas pela flexibilidade, pluralidade, 
fluidez e descentralização. O modelo rizomático é apropriado para caracterizar essas novas associações, uma vez que

o rizoma conecta um ponto qualquer com outro ponto qualquer e cada um de seus traços não remete necessariamente a traços de mesma natureza; [...] Ele não é feito de unidades, mas de dimensões, ou antes de direções movediças. Ele não tem começo nem fim, mas sempre um meio pelo qual ele cresce e transborda. (DELEUZE; GUATTARI, 1995, p. 32). 


\section{FÓRUM SOCIAL MUNDIAL}

\subsection{O MOVIMENTO DE RESISTÊNCIA E O SURGIMENTO DA AÇÃO POLÍTICA AUTÔNOMA EM REDE}

Da perspectiva do contexto sociopolítico mundial das últimas décadas do século $X X$, alguns analistas afirmam que vivemos uma nova fase da economia mundial, enquanto que outros defendem que estamos presenciando um momento de ruptura que começou com o colapso da União Soviética. Viveríamos, então, um processo de transição ainda em curso, que apresenta grandes mudanças em relação ao período após a Segunda Guerra Mundial, quando muitos países passavam por uma fase de expansão econômica, que incluía o Estado do bem-estar social nos países centrais, desenvolvimentismo em boa parte da periferia e expansão dos direitos sociais. O mercado mundial era estruturado por economias nacionais e, politicamente, as duas grandes potências - Estados Unidos e União Soviética - protagonizavam a cena internacional. Nessa época, a cultura política de resistência propunha uma revolução das massas, do chamado proletariado, com o objetivo de conquistar o poder político.

A partir de 1973, as recessões banidas desde a guerra retornam e com a recessão do início dos anos 80 , as políticas neoliberais se impõem, fortemente representadas pelos governos de Ronald Reagan (presidente dos EUA de 1981 a 1989) e Margaret Thatcher (Primeira Ministra da Inglaterra de 1979 a 1990), cujos governos passaram a ser hegemônicos na cena política priorizando a

Abertura de mercados e liberalização econômica, redução de intervenção do Estado na economia e desregulamentação, privatização e garantia da propriedade intelectual, redução dos gastos sociais e aumento da competitividade global [que] tornaram-se mandamentos inquestionáveis, sancionados pelo Fundo Monetário 
Internacional (FMI), pelo Banco Mundial (BM), pela Organização Mundial de Comércio (OMC), pelo G-8 e pela União Européia (EU) (LEITE, 2003, p. 10).

Após a queda do Muro de Berlim, em 1989, e do bloco socialista, houve um deslocamento das relações de força em favor dos setores ligados ao capital. O capitalismo se apresentava como única opção possível, como um modelo econômico apto a oferecer progresso a toda humanidade. Com o processo de globalização em curso, o capitalismo avançava rumo à constituição de uma sociedade mercantil a nível mundial, reforçando o pensamento dominante que deixava de lado qualquer possibilidade de alternativa político-ideológica.

O aspecto mais forte desse processo histórico é a globalização, com a mundialização do capital e a reestruturação radical das relações sociais em nível mundial. Apesar de se desenvolver de formas diferentes em várias regiões, algumas características são comuns a essa dinâmica, tais como: uma reorganização do processo de produção, utilizando as novas tecnologias baseadas na microeletrônica e as novas tecnologias de comunicação e organizando a força de trabalho através de medidas destinadas a aumentar a taxa de exploração (flexibilização, precarização, terceirização do trabalho); as fusões de corporações; a presença mais efetiva das instituições ligadas à globalização; aumento de inseguridade social. Essa recomposição provoca a sujeição de todos os âmbitos da vida social à lógica do mercado.

Na era da "modernidade líquida" em que vivemos, diria Bauman, a leveza e a mobilidade do capital são as principais fontes de incerteza para grande parte da humanidade. Atualmente, quando o espaço perde seu valor estratégico, pois pode ser atravessado instantaneamente, a velocidade do movimento se tornou a principal base da dominação. Nesta era de fluidez, o poder se tornou extraterritorial. 
O período de 1990 a 1997 é visto como o de maior força e predomínio do discurso neoliberal da globalização, onde qualquer questionamento era entendido como um posicionamento atrasado em relação ao chamado progresso. Apesar de já haver alguma discussão sobre a dissolução do modelo de bem-estar social e dos recentes problemas decorrentes da financeirização da economia, ainda não havia debate sobre alternativas nem sobre o chamado movimento antiglobalização.

Até o final dos anos 90 esse pensamento único era dominante, apesar da existência de alguns movimentos dissonantes, como o Exército Zapatista de Libertação Nacional (EZLN). Os zapatistas inovaram a atuação política em 1994 na região de Chiapas, México, ao se manifestarem contra o NAFTA (North America Free Trade Area), um acordo de livre comércio entre México, Estados Unidos e Canadá.

A região de Chiapas é repleta de contrastes. É rica em recursos naturais que propiciam energia elétrica ao país, petróleo, gás, milho, café, banana, cacau, gado e frutas, além de vários tipos de madeira. Entretanto, é um dos estados com altos índices de marginalização, desnutrição, falta de atendimento médico, analfabetismo e pobreza. A expulsão de comunidades locais para terras menos férteis tem sido um problema recorrente. Segundo a análise de Juan González Esponda e Elizabeth Pólito Barrios, a revolta zapatista que ficou mundialmente conhecida e reconhecida como um dos movimentos iniciais de resistência global é resultado do conjunto de vários processos: o problema agrário, a modernização da economia local, o desenvolvimento político-ideológico de um amplo movimento camponês e popular, a violência por parte do governo e a falta de democracia.

A luta zapatista conseguiu evidenciar a relação de processos globais com experiências locais e possui um significado particular no contexto mundial porque 
um aspecto do processo de reorganização social mundial é a destruição das velhas identidades, certezas e formas de luta, como nos explica John Holloway. De acordo com sua percepção, a luta zapatista não é em busca de autonomia indígena, nem de soberania mexicana, mas sim, de afirmar e ao mesmo tempo superar uma identidade. Ainda segundo o autor, sua repercussão deve-se, entre outros motivos que serão apresentados a seguir, a este princípio de ir contra a identificação, a definição, em contraposição ao princípio do poder que procura tudo classificar, definir, etiquetar. As implicações que surgem em decorrência deste conceito amplo e fluido de identidade referem-se à necessidade de buscar novas formas de articulação baseadas na escuta do outro, em um processo de não impor a própria verdade, senão que de unir as verdades das diferentes partes. Implica, ainda, em abandonar a ideia de partido político, uma vez que estes representam grupos baseados numa identidade comum que funciona através de processos hierárquicos.

os zapatistas são o pivô entre o velho modelo guerrilheiro e o novo modelo de estruturas biopolíticas em rede. Também demonstram esplendidamente como a transição econômica do pós-fordismo pode funcionar igualmente em territórios urbanos e rurais, ligando experiências locais a lutas globais. Os zapatistas [...] usam a Internet e as tecnologias de comunicação não apenas para distribuir seus comunicados para o mundo exterior como também, pelo menos em certa medida, como elemento estrutural dentro de sua organização, especialmente na medida em que ela se estende para fora do sul mexicano, alcançando os níveis nacional e global. A comunicação é um elemento central da concepção de revolução dos zapatistas, e eles estão constantemente enfatizando a necessidade de criar organizações horizontais em rede, em vez de estruturas verticais centralizadas. (HARDT; NEGRI, 2005b, p. 123)

Para compreender melhor as ações e a ressonância do grupo zapatista, é importante conhecer os três conceitos fundamentais que norteiam sua atuação. Como resume Ana Esther Ceceña, o primeiro deles se refere à priorização do consenso como princípio básico para fazer das decisões uma possibilidade real, que conte com a participação coletiva e não gere, por sua vez, resistências. O fato de ser 
um processo mais lento em relação à tomada de decisão unilateral permite marcar o rumo e a medida do que se pode alcançar naquele momento. Segundo esta lógica, de nada valeria acelerar um processo que, por não ter uma aceitação geral do grupo, se tornaria insustentável devido a oposições internas presentes desde o início. O segundo conceito é chamado de "mandar obedecendo", que trata das estruturas e dinâmicas de representação, isto é, de como os encarregados de executar as atividades definidas por consenso podem e devem agir sempre de acordo com as demandas do grupo. A pessoa responsável por mandar é quem deve obedecer às decisões do coletivo e, caso se afaste deste caminho, outra pessoa será designada para ocupar seu lugar, permitindo uma compatibilidade entre governantes e governados. Esse princípio permite a construção de relações horizontais, em oposição à estrutura da maioria das instituições e partidos políticos. Finalmente, o terceiro princípio norteia a construção de um mundo que inclua vários mundos, ou seja, a emancipação humana pressupõe a eliminação da alteridade, mas não da diversidade. Todos os mundos são possíveis porque nenhum se impõe sobre os outros e preza-se o respeito da diferença.

O Exército Zapatista de Libertação Nacional inovava em seus discursos, repletos de ironia e poesia, em suas ações e em seus objetivos. Ele não visava tomar nem destituir o governo, ou seja,

Em vez de uma revolução tradicional, os zapatistas conquistaram um
espaço de autodeterminação que se manifestava em municipalidades
autônomas, onde se retomavam os vínculos comunitários e se
desenvolviam formas avançadas de democracia direta. Essas
municipalidades autônomas, em certo sentido, existiam dentro da
sociedade capitalista, mas em oposição a ela. Elas coexistiam em
conflito, criando um gérmen anticapitalista dentro da sociedade atual.
(ORTELLADO; RYOKI, 2004, p. 30 , grifo do autor)

Hardt e Negri nos oferecem um abrangente panorama sobre os fundamentais modelos de ativismo político e atuação de organizações revolucionárias. A 
genealogia apresentada em sua obra Multidão trata desde as lutas de libertação, passando pela constituição de exércitos populares nas revoluções modernas, pela formação das guerrilhas até as formas contemporâneas de luta em rede. Recuperaremos aqui alguns pontos que podem nos ajudar a compreender algumas questões.

Em contraposição ao exército revolucionário unificado que era o objetivo dos coletivos de resistência na modernidade para unir sob uma única estrutura os grupos que se encontravam dispersos, nos anos 60 surgem organizações guerrilheiras em diversas partes do mundo, que buscavam através de um novo modelo organizacional, mais liberdade e democracia. Segundo análise dos autores, havia vários focos que podiam atuar com uma certa independência uns dos outros, gerando uma organização policêntrica e horizontal entre as unidades, em oposição à forma verticalizada e centralizada do exército tradicional.

Hardt \& Negri observam que após 1968, iniciou-se uma mudança na forma dos movimentos de resistência e libertação que estava ligada às modificações na força de trabalho e nas formas de produção social. Primeiramente, essa mudança se dá em decorrência do deslocamento dos movimentos de guerrilha, que começaram a sair do campo e se estabelecer nas cidades. Em segundo lugar, as técnicas utilizadas por esses grupos se modificaram para se adequar às novas características da produção pós-fordista, passando a trabalhar em sintonia com os sistemas de informação e as estruturas em rede. Ao longo das últimas décadas do século XX, principalmente nos Estados Unidos, surgem os movimentos conhecidos como de "política de identidade" ou estudos culturais de gênero, raça etc.

Mulheres, negros, homossexuais, grupos ecológicos, povos indígenas, jovens se articulam em prol de suas demandas, buscando em suas ações e forma 
organizacional autonomia, recusa de hierarquia centralizada e de líderes. As estruturas anteriores de partidos políticos, exército popular ou grupos guerrilheiros que buscavam sempre impor uma unidade são agora rejeitadas e o objetivo de tomar o poder cai em desuso. O termo "movimentos sociais" surge para se referir a esta diversidade de sujeitos. Desse modo, a forma de atuação desses grupos vai se consolidando em um formato mais aberto, mais fluido, descentralizado.

as forças guerrilheiras são policêntricas, compostas de numerosos focos relativamente independentes, mas essa pluralidade deve em algum momento ser reduzida a uma unidade, tornando-se as forças guerrilheiras um exército. A ordenação em rede, em contrapartida, baseia-se na pluralidade contínua de seus elementos e redes de comunicação, de tal maneira que a redução a uma estrutura de comando centralizada e unificada é impossível. A forma policêntrica do modelo guerrilheiro evolui assim para uma forma em rede na qual não existe um centro, apenas uma pluralidade irredutível de nodos em comunicação uns com os outros. (HARDT; NEGRI, 2005b, p. 120, grifo do autor).

O modelo neoliberal de desenvolvimento começa a revelar suas fragilidades num cenário de grande instabilidade e algumas consequências já podem ser observadas, tais como o aumento das desigualdades sociais, o desemprego, a precarização dos direitos sociais, entre outras. Com isso, a partir de 1997 há um crescimento e uma aceleração das ações de resistência como protestos, marchas e campanhas internacionais em diversas partes do mundo, questionando a legitimidade deste modelo e demonstrando o descontentamento em relação à vida e ao mundo conforme estabelecidos.

Havia anos estava se desenvolvendo em vários países um movimento por justiça global, coalizão de uma série de movimentos, entidades, organizações e redes que lutavam contra o que chamavam, nos países de fala inglesa, de corporate globalization (globalização das corporações), ou que na França eram altermundialistes (por uma outra mundialização). Em contraposição às forças hegemônicas que impulsionavam a mercantilização de todas as esferas sociais, formarase um movimento de movimentos que sustentava que "o mundo não é uma mercadoria" e que "o mundo não está à venda". A globalização neoliberal fora, afinal, apresentada ao seu outro reprimido, ao fantasma capaz de assombrá-la, que sua propaganda chamaria pejorativamente de movimento "antiglobalização". (LEITE, 2003, p.11). 
Inaugurando uma onda de protestos contra os organismos multilaterais que legitimavam o domínio dos mercados, em 30 de novembro de 1999, em Seattle, nos EUA, 50 mil manifestantes bloquearam a cidade, impedindo a realização da terceira reunião ministerial da Organização Mundial do Comércio (OMC) que visava, essencialmente, dar início a um novo ciclo de negociações (a Rodada do Milênio) para liberalização comercial, com foco na agricultura e em serviços como educação, saúde, atividades ambientais e culturais.

Meses antes do encontro, milhares de pessoas e organizações vinham se articulando nacional e internacionalmente para preparar a ação de protesto. Principalmente via internet, os participantes se comunicavam e se articulavam, formando uma grande e diversificada coalizão, planejando e organizando a infraestrutura necessária, os treinamentos de ativistas em técnicas de ação direta não violenta e a produção de atividades artísticas e culturais responsáveis pelo ambiente festivo dos protestos.

Chegada a hora, diversas ruas da cidade foram bloqueadas e, com isso, os manifestantes conseguiram impedir partes importantes da reunião, adiando para uma nova rodada as negociações para a liberalização comercial. Os cinco dias de protestos provocaram o cancelamento de atividades previstas e atrapalharam significativamente os objetivos do encontro. O acontecimento acabou gerando um enorme impacto na mídia.

Esse protesto tornou-se um marco na cena política mundial, pois mostrou que havia uma forte oposição à globalização em curso, revelando a possibilidade de contestar e transformar a situação existente. Além disso, os protestos de Seattle contra a OMC inauguraram o chamado movimento global, que passou a fazer parte 
da cena política internacional a partir de então. Inicia-se, dessa forma, um intenso ciclo de protestos e a cada nova reunião das principais instituições mundiais esse novo movimento plural se manifesta, gerando consequências políticas e simbólicas, deslegitimando estas instituições.

Com o objetivo de oferecer uma cobertura dos protestos contra a OMC em Seattle, surge o Centro de Mídia Independente (CMI) em 1999, composto por organizações independentes e alternativas, bem como por ativistas que trabalhavam com mídia. Através de uma rede descentralizada e autônoma, o centro teve um papel bastante importante na ocasião, oferecendo informações, reportagens, fotos e vídeos em tempo real através do site na internet. Com a repercussão das ações em Seattle, outros grupos formaram centros de mídia independente em diversas cidades e países, inicialmente para fazer a cobertura jornalística dos protestos que estavam sendo realizados no mundo todo, mas depois permanecendo como uma central de notícias independente. O princípio é o de propiciar uma estrutura no site que permita a qualquer pessoa incluir textos, vídeos e sons, tornando-se um meio participativo que funciona através da colaboração voluntária de grupos e pessoas e uma alternativa à mídia empresarial, principalmente no que se refere à cobertura sobre os movimentos sociais de ação direta. Estimula-se a ação autônoma dos indivíduos que, com sua participação, contribuem para a manutenção de um espaço aberto de publicação de informações e troca de opiniões.

Outro momento importante da onda de protestos foi durante a reunião anual do Fundo Monetário Internacional (FMI) e do Banco Mundial na cidade de Praga, na República Checa, em setembro de 2000, onde novas ações foram realizadas. Aproximadamente 20 mil manifestantes usaram as táticas de Seattle, como forte organização prévia via internet, tentativas de bloquear a reunião e confrontos 
sistemáticos com a polícia. Novamente bem-sucedido, o protesto foi capaz de antecipar o término da reunião.

É importante destacar que a proposta de se realizar um fórum em contraposição ao encontro anual de Davos, o Fórum Econômico Mundial, foi lançada durante um desses protestos, desta vez em Genebra, Suíça, em junho de 2000, contra II Cúpula Social das Nações Unidas. A proposta era realizar o Fórum Social Mundial em Porto Alegre, Brasil, no ano seguinte, encontro que seria capaz de estimular diferentes redes e movimentos para debater propostas e também para coordenar ações e protestos.

Um protesto também marcante, inclusive pela violência com que foi recebido foi o realizado em Gênova, Itália, contra o encontro do G-8, em julho de 2001. O maior protesto até então organizado, com cerca de 300 mil pessoas, revelou a possibilidade de construção de uma enorme e abrangente coalizão com a presença de movimentos de natureza diversificada constituindo uma mobilização em escala européia. No enfrentamento, o governo local empreendeu uma ação extremamente violenta, que culminou no assassinato de um jovem, fato que foi amplamente divulgado na mídia na ocasião.

O cenário apresentado revela a grande mudança que houve desde os anos 80 em termos de perspectivas ideológicas, de constituição do panorama sociopolítico internacional e de transformações na dinâmica cultural, agora com uma forte presença da ação autônoma de diversos grupos articulados em rede.

Já estamos, então, muito longe da situação em que o pensamento único exalado por um neoliberalismo agressivo parecia asfixiar toda crítica e impor a passividade perante a mercantilização da vida, da cultura e do mundo. Desde Seattle, o movimento mundial contra a globalização capitalista empolgava a juventude, despertava esperanças, restabelecia utopias e reconstruía o sentido de uma história aberta, feita pelos próprios seres humanos, por suas escolhas e lutas. Contra o obscurantismo da idolatria do mercado, que 
entorpecia a consciência humana ao colocar o capitalismo como o estado natural da sociedade, o novo movimento e uma nova geração militante instauram um campo de idéias e um espaço de ação política em que um outro mundo poderá ser possível, se lutarmos por ele. (LEITE, 2003, p. 57)

\subsection{O FÓRUM SOCIAL MUNDIAL: ORIGEM, CARACTERÍSTICAS E OBJETIVOS}

No início de 2000 alguns brasileiros discutiram a proposta de realizar um encontro de dimensão mundial voltado para as questões sociais, em oposição ao pensamento único do neoliberalismo e que fosse além dos protestos que vinham ocorrendo pelo mundo. O Fórum Social Mundial (FSM), iniciativa com o objetivo de promover a articulação e o encontro dos movimentos de resistência e de propor alternativas, tinha como parâmetro a experiência do Fórum Econômico Mundial de Davos e, portanto, para ter um efeito simbólico de oposição, seria realizado nas mesmas datas do encontro anual.

Nas palavras de Chico Whitaker, a ideia era

criar um evento similar, mas com pessoas preocupadas em centrar as decisões do mundo no ser humano e não nas necessidades do capital, ou seja, um Fórum Social Mundial. Este deveria reunir, numa perspectiva propositiva, todos os que estivessem participando do processo de manifestações contra a dominação do capital [...] Seria um encontro com o mesmo caráter de Davos, isto é, não-deliberativo, reunindo pessoas interessadas em discutir o mundo de forma alternativa. (WHITAKER, 2005, p. 147).

A proposta foi levada ao diretor do jornal Le Monde Diplomatique (Bernard Cassen), na França, que propôs que o encontro fosse realizado no Brasil, pelo efeito simbólico de ser realizado em um país em desenvolvimento, especificamente em Porto Alegre, capital de um estado que estava em evidência no mundo pelas suas experiências democráticas (orçamento participativo, apoio ao movimento pelo software livre, etc). No Brasil, verificou-se quais entidades estavam interessadas em 
se envolver na proposta e, no final do ano 2000 , oito entidades ${ }^{18}$ já haviam firmado um acordo para realizar o encontro.

O I Fórum Social Mundial foi realizado entre os dias 25 e 30 de janeiro de 2001, em Porto Alegre, Rio Grande do Sul. O número de participantes foi além do esperado, deixando evidente o sucesso do encontro. Embora a maioria dos participantes fosse de nacionalidade brasileira, muitos estrangeiros envolvidos nos ciclos de protestos em diversos países estavam presentes. Aproximadamente 20 mil pessoas, das quais cerca de 4.700 eram delegadas de diversas entidades abrangendo 117 diferentes países estiveram presentes no encontro. A imprensa também teve uma presença expressiva, com 1.870 credenciados.

A programação incluía 16 plenárias, 400 oficinas e 20 testemunhos, além de atividades paralelas e autônomas, como o Fórum Parlamentar Mundial, o Fórum de Autoridades Locais pela Inclusão Social e o Acampamento Intercontinental da Juventude (com aproximadamente dois mil participantes).

O Fórum revelou seu caráter plural, tanto em termos de atividades como de participantes, permitiu a expressão de experiências de construção de alternativas, o encontro de diversos indivíduos e grupos, a coexistência da diversidade e a troca de conhecimento, ajudando a promover uma ruptura com o pensamento único.

O Fórum ultrapassou todas as expectativas iniciais, impôs-se perante a mídia internacional e contestou a legitimidade do encontro de empresários e governantes em Davos. Apresentar o Fórum Social Mundial como anti-Davos, como contraposição afirmativa e frontal ao Fórum Econômico Mundial reunido na Suíça, Ihe deu uma marca de nascença muito forte. Ao mesmo tempo, a palavra de ordem 'Um outro mundo é possível' soube materializar seu caráter de espaço propositivo de troca de experiências, debate de alternativas e

\footnotetext{
18 Abong (Associação Brasileira de ONGs), Attac (Associação pela Tributação das Transações Financeiras em Apoio aos Cidadãos), CBJP (Comissão Brasileira de Justiça e Paz), Cives (Associação Brasileira de Empresários pela Cidadania), CUT (Central Única dos Trabalhadores), Ibase (Instituto Brasileiro de Análises Sociais e Econômicas, MST (Movimento dos Trabalhadores Rurais Sem Terra) e Rede Social de Justiça e Direitos Humanos.
} 
articulação de lutas, tão necessário ao heterogêneo movimento global que se conformava".(LEITE, 2003, p. 69).

O Fórum Social Mundial conseguiu reunir e agregar milhares de pessoas de várias partes do mundo em busca de um espaço de discussão de temas da atualidade e à procura de formas alternativas de se pensar e de se viver. O Fórum "surgiu num momento em que os instrumentos tradicionais de ação política mostravam definitivamente que são insuficientes, tal ineficácia tendo provocado decepção e sentimento de frustração". (WHITAKER, 2005, p. 152). Com a descrença em partidos políticos e nas opções de mudança que fracassaram no século XX, muitos indivíduos e grupos atuando isoladamente encontraram no Fórum um espaço que permite a expressão de suas ideias e o fortalecimento de suas ações. Com a possibilidade de entrar em contato com outras pessoas com objetivos semelhantes, o Fórum viabilizou a construção de redes; no lugar de pontos isolados espalhados pelo mundo, o Fórum cumpriu seu papel de elo de ligação. Muitas ações locais se transformaram em globais. Por outro lado, o contato com a imensa variedade de temas, ideias e pessoas, fez com que a experiência de vivenciar o clima do Fórum reascendesse esperanças e preenchesse de ânimo seus participantes, reafirmando o sentido de agir para a transformação do mundo.

Após o êxito do primeiro encontro e a definição da realização de uma segunda edição do Fórum Social Mundial em Porto Alegre, as entidades do Comitê Organizador Brasileiro adotaram dois procedimentos para dar continuidade aos encontros e reforçar o processo. Em primeiro lugar, a experiência do I FSM foi sistematizada em um documento chamado Carta de Princípios ${ }^{19}$. Segundo esse documento, o Fórum Social Mundial foi definido como "um espaço aberto de

\footnotetext{
${ }^{19}$ Ver ANEXO A.
} 
encontro para o aprofundamento da reflexão, o debate democrático de ideias, a formulação de propostas, a troca livre de experiências e a articulação para ações eficazes, de entidades e movimentos da sociedade civil empenhados na construção de uma sociedade orientada para uma relação fecunda entre os seres humanos e destes com a Terra; um processo de caráter mundial; um espaço que reúne e articula entidades e movimentos da sociedade civil de todos os países do mundo, mas não pretende ser uma instância representativa da sociedade civil mundial; será sempre um espaço aberto ao pluralismo e à diversidade de atuações das entidades e movimentos, bem como à diversidade de gênero, etnias, culturas, gerações e capacidades físicas", entre outras características. ${ }^{20}$

Em segundo lugar, organizou uma reunião com entidades internacionais parceiras com o objetivo de discutir o documento e formar um Comitê Internacional. Esperava-se que o Fórum exprimisse o caráter global dos protestos contra a mundialização capitalista e em busca de alternativas. Nessa reunião, com a presença de mais de 60 representantes de organizações não governamentais, redes e movimentos sociais da África, Ásia, Europa e Américas, formou-se um grupo internacional com caráter de Conselho, que foi gradativamente dividindo as discussões e responsabilidades com o Comitê Organizador. O principal objetivo do Conselho Internacional era a mundialização do Fórum Social Mundial. Para o grupo, o encontro não se resumia a um evento, mas se constituía como parte de um processo em formação. Além disso, o Conselho Internacional sugeriu que o II FSM deveria ter um caráter mais propositivo, incorporar temas ausentes e ampliar a participação de representantes de continentes como África e Ásia.

\footnotetext{
${ }^{20}$ Informações segundo a Carta de Princípios do Fórum Social Mundial, que pode ser encontrada através do site www.forumsocialmundial.org.br e também no ANEXO A no final deste documento.
} 
O II Fórum Social Mundial teve praticamente o triplo de participantes em comparação com a primeira edição, agregando aproximadamente 60 mil pessoas, sendo por volta de 12 mil delegados representantes de entidades de 123 países, mais de 3 mil jornalistas participando de 27 conferências, 96 seminários e 622 oficinas e outras atividades organizadas pelos participantes. A presença no Acampamento da Juventude também cresceu consideravelmente, reunindo mais de 10 mil pessoas no Parque Harmonia, revelando a forte participação dos jovens na autogestão dos espaços e das atividades através da experimentação de novas práticas.

O II Fórum Social Mundial, realizado entre os dias 31 de janeiro e 05 de fevereiro de 2002, se consolidou como espaço de encontro, diálogo e troca de experiências e reflexões do movimento global. Além do encontro anual, o Conselho Internacional se propôs a estimular fóruns regionais e continentais para reforçar o processo de mundialização do FSM. A construção de convergências durante o encontro teve como resultado prático a formação de um calendário global de mobilizações para os dois anos seguintes, mantendo as redes ativas e articuladas através de alguns objetivos em comum.

Diferentemente do que se via em outras épocas, grupos de naturezas diferentes (movimentos sociais, organizações não governamentais, centrais sindicais) conviveram durante o Fórum, atualizando ações e práticas, agora preservando o convívio da diversidade. Se, ao longo do século $\mathrm{XX}$, o objetivo era conseguir a homogeneidade social e política e a unidade dos atores sociais através de estratégias definidas por centros de comando, agora a ênfase está na diversidade social, cultural e política e na livre interação entre os grupos e indivíduos. 
Segundo as ideias de Boaventura S. Santos, as expressões que constituem o FSM não se encontram em nenhuma das vias de transformação social concebidas na modernidade ocidental, como os conceitos de reforma e revolução. A estrutura do FSM não corresponde a modelos de organização política moderna, mas apresenta diversas formas de atuação. Para o autor, apesar de se poder afirmar que estas características já estavam presentes no que se costuma chamar de "novos movimentos sociais", a diferença é que estes movimentos são temáticos e a separação por temas sempre gera atração dos semelhantes, por um lado, mas por outro, a repulsão. A novidade do Fórum é que ele é inclusivo, seja na abrangência da diversidade de grupos seja na das temáticas. "O FSM é global na forma como acolhe os movimentos locais, nacionais e globais, e no facto de ser intertemático e até transtemático" (Santos, 2005, p. 12).

Um outro aspecto interessante abordado pelo autor é que o Fórum Social Mundial

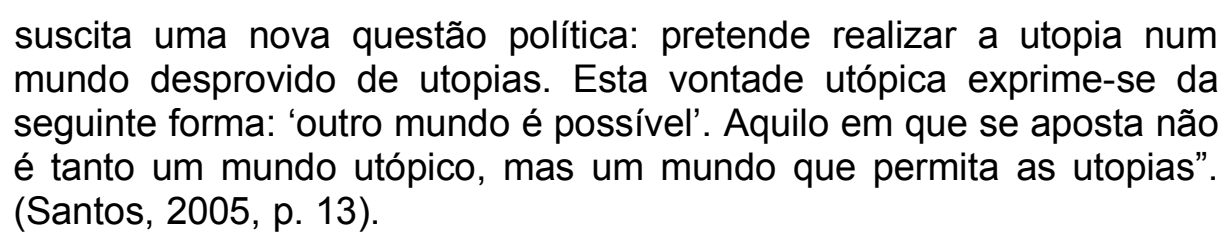

A terceira edição do encontro (23 a 28 de janeiro de 2003) foi ainda mais expressiva em termos de números, reunindo cerca de 100 mil participantes, dentre os quais aproximadamente 20 mil eram delegados de 130 países. Mais de 4 mil jornalistas se credenciaram para fazer a cobertura do evento e o Acampamento da Juventude recebeu desta vez por volta de 25 mil participantes. Em se tratando da programação, foram realizados: 10 conferências, 36 painéis, 22 testemunhos, 4 mesas de diálogo e controvérsia e 1.286 oficinas, seminários e outras atividades organizadas pelos participantes. 
Tendo em vista o crescimento do III FSM, as atividades se distribuíram em três locais principais da cidade, ao contrário dos outros anos, onde os espaços oferecidos por duas universidades davam conta de acolher todas as atividades.

Com uma maior participação do Conselho Internacional através de reuniões prévias e grupos de trabalho, a preparação das atividades teve um caráter mais internacional, tanto na questão das temáticas e de conferencistas quanto da metodologia.

Nos três primeiros fóruns a estrutura da programação foi semelhante, dividida, principalmente, em dois modelos: atividades organizadas pelo Comitê Organizador e pelo Conselho Internacional com conferencistas convidados por essas instâncias e atividades propostas pelas entidades participantes e seus delegados.

O êxito do Fórum Social Mundial está atrelado à novidade de seu caráter. Algumas das novas práticas adotadas, como bem explica Chico Whitaker (WHITAKER, 2005), podem ser assim descritas: o fórum como "espaço aberto", organizado segundo os princípios da horizontalidade e da não diretividade, ou seja, sendo um espaço sem donos nem dirigentes, ele permite que estejam reunidas diferentes expressões da sociedade civil em busca da construção de alternativas, não apenas uma, mas várias alternativas; sem uma voz de comando nem ordens específicas a serem seguidas como nas estruturas piramidais tradicionais, "o fórum acaba por se tornar um momento intenso de vida em rede, sem chefes nem comandos, com a garantia da absoluta autonomia de cada entidade, movimento ou pessoa". (WHITAKER, 2005, p. 53). Seu caráter aberto também significa que ele não é deliberativo, não toma posições nem dá diretrizes a seus participantes. Para manter seu caráter aberto e plural, não há documento final produzido em nome do Fórum. 
As atividades auto-organizadas (propostas e organizadas por movimentos e entidades participantes) desde o início revelaram-se como uma oportunidade para que os grupos participantes apresentem o trabalho que vêm desenvolvendo em suas organizações, incentivando uma participação ativa no lugar da passividade de apenas assistir a uma mesa de conferências e, além disso, essas atividades mostraram a enorme riqueza temática e a diversidade presentes nos encontros. Uma conseqüência desse modelo de atividade é a experiência da autogestão, princípio que encoraja a autonomia e a cidadania corresponsável, fundamentais para a construção de uma sociedade mais participativa e democrática; as entidades são responsáveis por inscrever suas atividades, prepará-las e apresentá-las na data e horário definidos, tendo toda a responsabilidade pela realização de sua atividade e pela construção, no conjunto, do programa de cada Fórum.

O Fórum Social Mundial cumpre um papel de intermediário, pois ele oferece as condições necessárias para que, por intermédio dos Fóruns, sejam lançadas inúmeras propostas e iniciativas que ajudem na construção de um outro mundo. $O$ papel do Fórum na mediação e sua ênfase no processo em si é também uma novidade em termos de prática.

Tendo como objetivo a internacionalização do processo Fórum, definiu-se que - IV Fórum Social Mundial seria realizado em Mumbai, na Índia, um país com tradição de ativismo progressista da sociedade civil. A experiência do FSM expandiu-se, desse modo, para muitas entidades e indivíduos pouco envolvidos no processo até então, principalmente devido à localização geográfica, que dificultou a presença africana e asiática nos encontros realizados no Brasil. Como forma de preparação, foi realizado o Fórum Social Asiático em 2003, considerado um sucesso, e comitês e grupos de trabalho foram formados para dar início ao processo 
organizativo do FSM 2004. É importante ressaltar que no quarto fórum, foram realizadas modificações no formato da programação: uma parte das atividades que antes eram organizadas pelo Comitê Organizador passou a ser organizada pelas próprias entidades participantes e houve maior espaço para atividades artísticas e manifestações. A presença de grupos musicais, teatrais e de dança foi notável, revelando o espírito alegre do encontro e oferecendo aos participantes uma oportunidade de interagir com a enorme diversidade cultural do país. Nos espaços de circulação, as manifestações em diversos formatos eram constantes, o que dava voz a muitos grupos que sofrem com a opressão e a exclusão.

Num país de grandes desigualdades, foram tomadas algumas medidas para que a participação nas instâncias organizativas do encontro e nas próprias atividades fosse ampliada, incluindo os grupos sociais menos visíveis e mais marginalizados. Com esse objetivo, foram realizadas consultas nacionais para convocar a participação de entidades representativas desses grupos; decidiu-se, também, acentuar a importância das atividades auto-organizadas (organizadas pelas entidades participantes), planejando os horários de modo que estas não concorressem com as atividades organizadas pelo Comitê Organizador; buscou-se, ainda, fazer com que o perfil social dos participantes revelasse essa situação de desigualdade e exclusão, através da participação de mais de 30 mil dalits (quase um terço dos participantes), conhecida como a casta mais baixa no sistema de castas indiano (SANTOS, 2005).

De um modo geral, o Fórum Social Mundial realizado em Mumbai foi considerado um sucesso e um salto qualitativo no processo Fórum. Com mais de 100 mil participantes, o encontro conseguiu garantir uma forte presença popular e 
oferecer espaço para uma maior diversidade de expressões, incluindo marchas, caminhadas, além da vasta programação cultural e artística.

Apontamos aqui as quatro principais razões para esse sucesso, de acordo com análise realizada por Boaventura de S. Santos (SANTOS, 2005). A primeira razão afirma que a decisão de realizar o FSM em Mumbai foi bastante acertada, pois

Com a sua população de quase 15 milhões, Mumbai é o símbolo vivo das contradições do capitalismo no nosso tempo. Um importante centro financeiro e tecnológico e sede da pujante indústria cinematográfica da Índia - Bolywood, produzindo mais de duzentos filmes por ano [...] -, Mumbai é uma cidade cuja pobreza extrema facilmente agride os olhos ocidentais. Mais de metade da população vive em bairros de lata (cerca de dois milhões nas ruas), enquanto $73 \%$ das famílias, geralmente grandes, habitam casas com uma só divisão. A recente expansão da economia informal converteu $2 \%$ da população em vendedores de rua. (SANTOS, 2005, p. 84).

Segundo, esse fórum mostrou que o espírito dos encontros realizados anteriormente em Porto Alegre, apesar de demonstrarem aspirações universais, revelavam características específicas de acordo com o local geográfico. De fato, as desigualdades provocadas pelo sistema de castas indiano e o fundamentalismo religioso presente na Ásia foram questões expostas nacional e internacionalmente, voltando os olhares para especificidades da região, numa dinâmica de levar as questões locais para uma discussão em âmbito global.

Em terceiro lugar, o Fórum chamou a atenção para a luta pela paz, uma vez que os conflitos armados e a presença de armas nucleares são parte da realidade na região. E, por último, o FSM 2004 ampliou o conceito de "lutas ecológicas", incluindo também "a luta pela soberania alimentar, pela terra e pela água, bem como a preservação da biodiversidade e dos recursos naturais, e a defesa das florestas contra a agro-indústria e a indústria da madeira" (SANTOS, 2005, p. 84). 
O Fórum Social Mundial 2005 foi novamente realizado em Porto Alegre. De volta ao Brasil, a quinta edição do encontro contou com uma nova metodologia que pretendia unir da melhor forma possível os temas com os interesses das entidades participantes e promover um maior número de articulações e ações comuns. Para tal, um questionário foi formulado e enviado às organizações e movimentos envolvidos no processo Fórum, pedindo que identificassem os temas, discussões e propostas que eles gostariam de ver representados no encontro e em que tipo de atividade e também quais atividades pretendiam realizar. Além disso, com base na experiência vivida no IV FSM na Índia, optou-se por abrir mais espaço para as diversas formas de expressão cultural e artística; através da própria ficha de inscrição era possível registrar e programar atividades como celebrações, performances, exposições de artes plásticas, mostras audiovisuais, entre tantas outras. Os principais objetivos da nova metodologia podem ser assim descritos:

1- construir todo o programa do FSM debaixo para cima, de tal maneira que todas as actividades serão autogeridas no sentido forte do termo; 2- maximizar a possibilidade de articulação e de acção comum entre organizações, convidando-as a encetar um diálogo sustentado que conduza à aglutinação de actividades propostas para o Fórum. (SANTOS, 2005, p. 87).

Essa metodologia permite que entidades se comuniquem e façam atividades em conjunto e potencializa a comunicação e a troca de conhecimento. Além disso, a articulação entre as organizações e movimentos pode ser permanente: antes, durante e depois do encontro. Esse novo formato demanda mais trabalho por parte das entidades, mas revela-se mais democrático, participativo e estimula a continuidade das ações.

Entre as muitas inovações introduzidas, visou-se estimular as articulações e a formulação de planos de ação antes mesmo do evento. Criou-se também a possibilidade de que os participantes contassem com um espaço de tempo livre, cada dia, para discutir articulações e programar ações concretas. (WHITAKER, 2005, p. 62). 
Desde 2003 o movimento global que se constituiu a partir dos protestos de Seattle vinha passando por uma fase de relativa dispersão; suas ações estavam mais focadas nos níveis regional e nacional, revelando uma certa dificuldade de manter a força e a articulação em nível global presenciada de 1997 a 2001.

Desse modo, para expandir ainda mais o processo e promover uma maior articulação em nível mundial, optou-se por realizar a sexta edição do Fórum Social Mundial de forma policêntrica, em três continentes simultaneamente (africano, americano e asiático), sempre em países em desenvolvimento. O encontro ocorreu em três locais: Bamako (Mali), Caracas (Venezuela) e Karachi (Paquistão), em datas próximas, de janeiro a março de 2006.

Os dois fóruns seguintes ainda foram realizados sob o princípio de expansão do processo, sendo o de 2007 em Nairobi (Quênia) e o de 2008 um evento descentralizado, ou seja, uma semana de mobilização e ação global, marcada por um dia de visibilidade mundial (26 de janeiro de 2008).

Apesar das inúmeras dificuldades em termos de organização e de condução do VII FSM (problemas de infra-estrutura e pouca presença de movimentos populares, por exemplo), ele foi importante justamente por ser realizado na África e por ser capaz de integrar diferentes grupos do continente, além de ser uma oportunidade para que os participantes não africanos conhecessem melhor a situação da população local.

Diversas entidades criticaram o FSM realizado em Nairobi e o avaliaram como decepcionante $^{21}$. Entretanto, nem todos compartilham da mesma opinião. Em um balanço sobre o encontro, Chico Whitaker afirma que

\footnotetext{
${ }^{21}$ Segundo balanços publicados no site do Fórum Social Mundial: www.forumsocialmundial.org.br
} 
em Nairobi, em 2007, tornou-se possível começar a superar a separação entre povos, entre nações e mesmo entre etnias em todo o continente africano [...] o Fórum de 2007 reuniu, pela primeira vez na história da África, organizações da sociedade civil de todos os seus países. Com isto permitiu que se desse um primeiro passo [...] para a construção da união entre seus povos, abrindo perspectivas e condições inteiramente novas para a superação de seus problemas (WHITAKER, 2007).

O evento de 2008 foi chamado de Dia de Mobilização e Ação Global, uma jornada internacional com mais de 700 atividades que aconteceram em mais de 80 países. Foi disponibilizado um site ${ }^{22}$ para que qualquer participante pudesse publicar imagens, vídeos, arquivos de áudio, notícias e páginas colaborativas, ajudando a construir a memória coletiva do evento.

Recentemente, o FSM 2009 realizado em Belém (Pará, Brasil), de 27 de janeiro a $1^{\circ}$ de fevereiro, marcou um momento de retomada do processo. $\mathrm{O}$ contexto mundial de crise do modelo econômico dominante reafirma o projeto do Fórum Social Mundial, como se comprovasse os limites da globalização e do modo de vida que vêm sendo o norte das sociedades. O fato de ser na região amazônica também chamou a atenção para a crise ambiental em que o planeta está imerso; o contato diário dos participantes com a riqueza da biodiversidade da região, com a presença imponente do rio e com as fortes e repentinas chuvas tornavam o tema da relação com a Natureza constantemente presente.

Foi marcante a presença indígena ${ }^{23}$, com o encontro de povos indígenas da região da Amazônia, dos Andes e de todo o continente. Em uma atividade sobre o tema em que esta pesquisadora teve a oportunidade de estar presente ${ }^{24}$, um

\footnotetext{
${ }^{22}$ www.wsf2008.net

${ }_{23}$ Estima-se que aproximadamente 1.900 indígenas de 120 etnias e nações distintas estiveram presentes, segundo matéria na revista Fórum, n 71, p. 12.

${ }^{24}$ A atividade The Politics, Potencials, and Meanings of the WSF in Belem: The Significance for the WSF of the Participation of the Indigenous Peoples of the World (A política, potenciais e significados do FSM em Belém: o significado para o FSM da participação dos povos indígenas do mundo) foi realizada em 29/01/09, na Universidade Federal do Pará (UFPA), pelas organizações CACIM (India Institute for Critical Action: Centre In Movement) e NFFPFW (National Forum of Forest People and Forest Workers),
} 
representante indígena da Colômbia afirmou a importância do Fórum Social Mundial para que esses grupos se encontrem, possam trocar experiências e formar amplas articulações pelo continente em busca de objetivos comuns. Para ele, a articulação local já é muito difícil em função da violência e marginalização que sofrem, sem contar as dificuldades de sobrevivência em função de mudanças climáticas e da poluição das águas e terras onde vivem. Dessa forma, apesar de ser o início de um processo, esse fórum inaugura a inclusão dos grupos indígenas em suas atividades e espaços e traz suas questões para o universo dos demais participantes.

Uma nova metodologia reuniu no final deste encontro milhares de participantes nas Assembléias temáticas e na Assembléia das Assembléias, onde os resultados e declarações das atividades foram apresentados. Após uma sistematização realizada pelo Conselho Internacional do Fórum Social Mundial, foi montado um calendário comum de mobilizações globais para 2009 e 2010.

Através de um olhar retrospectivo, pode-se afirmar que as primeiras edições do Fórum Social Mundial (2001 a 2003) foram marcadas principalmente pela articulação do calendário de mobilizações globais. Os encontros foram capazes de captar as experiências e aspirações da pluralidade de atores que, desde Seattle, vinham se mobilizando e buscando alternativas de sociedade em escala global. $\mathrm{O}$ FSM em Mumbai (2004) complementou e contribuiu significativamente com o processo, ao possibilitar uma participação mais abrangente e uma metodologia mais aberta. Essa primeira fase do processo foi de crescimento e ampliação da participação, através da construção de uma nova dinâmica de ações e práticas. Entretanto, o contexto mundial se modificou e a atuação do Fórum Social Mundial 
também tomou novos rumos. Como nos explica José Corrêa Leite, em um balanço sobre o último encontro

este movimento, do qual o FSM é uma expressão, não foi capaz de enfrentar a mudança na correlação de forças estabelecida pela militarização das relações internacionais imposta por Bush, depois da invasão do Iraque em 2003, relação alavancada pelo ciclo de forte expansão econômica mundial de 2002 a 2007. O FSM 2005 já se realizou em uma conjuntura mundial muito mais adversa, sem que o movimento global tivesse novas propostas ou capacidade de sustentar o nível prévio de mobilização. Fragmentação e recuo para os marcos nacionais ou regionais deram a tônica global neste período, com a dinâmica de busca de alternativas na América Latina diferenciando-a dos demais continentes. (LEITE, 2009, p. 2).

Nesse contexto, foram realizados os Fóruns de 2006 a 2008, numa fase onde a novidade que caracterizava a construção de uma nova dinâmica já não ocupava o lugar central. Nesse período, a solução encontrada foi a de realizar os encontros em formatos diferentes para promover sua expansão em nível mundial. Com o FSM 2009, observa-se um momento importante de retomada do processo. Dois fatores merecem destaque a esse respeito: em primeiro lugar, a crise mundial abre espaço para novos questionamentos sobre o modelo socioeconômico e cultural dominante e, em segundo lugar, o fato de o encontro ter sido em Belém permitiu a participação de novos atores e a exposição de novas concepções de vida e de construção de mundo, o que renova o movimento altermundialista.

$\mathrm{Na}$ avaliação de conjunto apresentada no final da obra de José Corrêa Leite (LEITE, 2003), alguns aspectos sobre as características do Fórum Social Mundial são analisados. Para concluirmos este subcapítulo, vale resgatarmos alguns pontos importantes apresentados em sua síntese.

Em primeiro lugar, "o FSM é um espaço, e não uma organização”, no sentido de que ele promove um lugar de diálogo, encontro, apresentação de propostas, troca de experiências, articulação de grupos existentes e formação de novas redes. 
Desse modo, o Fórum em si não apresenta posicionamentos nem declarações finais embora seus participantes possam fazê-lo livremente em nome de suas organizações e redes. O Fórum garante, assim, a preservação da diversidade nos encontros.

Em segundo lugar, "O FSM é um processo, e não só um evento, e é parte de um movimento mais amplo". Como foi dito anteriormente, diversos fóruns regionais, continentais e temáticos vêm sendo realizados mundo afora desde o surgimento do I Fórum Social Mundial. Essa dinâmica mostrou que o FSM não é apenas um encontro pontual, e sim que ele se transformou em um processo mundial, que viabiliza encontros entre pessoas, permite a formação redes onde é possível trocar conhecimentos e estabelecer ações comuns e oferece condições para o crescimento e a articulação dos movimentos sociais e diversos grupos da sociedade civil.

Em terceiro, "o FSM vem contribuindo para alterar o clima ideológico do mundo atual", ou seja, no lugar do pensamento único o fórum abre espaço para novos horizontes e perspectivas. A possibilidade de apresentar e participar de atividades sobre diversos temas, o fato de conhecer propostas de alternativas à forma como o mundo e a vida estão constituídos é muito enriquecedora para os participantes. Ao observar a quantidade de pessoas reunidas propondo alternativas e atuando com otimismo, criatividade e ousadia em busca desse objetivo, o sentimento coletivo de esperança e ânimo se fortalece, dando estímulo para a continuidade das atividades de resistência.

O quarto aspecto aponta que "os fóruns vêm se mostrando o lugar por excelência de encontro e incorporação no movimento de uma nova geração política", isto é, a presença da juventude tem sido marcante nesses encontros, revelando seu anseio pela participação e pela construção de novas formas de vida. Através de 
novas práticas e iniciativas, a participação dessa nova geração permite renovar as formas de atuação política.

Em quinto lugar, "o processo FSM tem, todavia, que lidar com contradições importantes, constitutivas do que é o Fórum". Segundo a análise, essas contradições, se não podem ser facilmente superadas, devem ser administradas e elaboradas ao longo do processo. Isso diz respeito ao momento de transformações pelas quais a sociedade passa, então o FSM oferece espaço a forças emergentes, mas também a processos cujo modelo se remete à etapa histórica anterior. Um dos exemplos é a relação do FSM com partidos políticos. Pela Carta de Princípios do FSM, partidos políticos, governos e organizações armadas não propõem atividades nem enviam delegados ao encontro. Embora o fórum procure dar espaço a expressões da sociedade civil não estruturadas através das instituições tradicionais de disputa de poder, de alguma forma, diversas correntes políticas se expressam no fórum, fazendo com que sempre exista uma tensão em se tratando dessa questão.

Finalmente, um último aspecto aponta que a crise de representação política que se vê na sociedade atualmente aliada ao fato de os partidos políticos não participarem diretamente do FSM, provoca o surgimento da "demanda de que o próprio Fórum cumpra o papel de direção". Entretanto, os fóruns são espaços e as instâncias organizadoras agem como facilitadores do processo, não pretendendo assumir um papel diretivo. Em outras palavras,

a metáfora adequada para visualizar o movimento atual e o Fórum é a da rede, e não a da pirâmide, ligada a uma etapa histórica passada (do fordismo, da analogia entre partidos e exércitos etc.). (LEITE, 2003, p. 125). 


\subsection{O FÓRUM SOCIAL MUNDIAL E AS REDES}

Como desenvolvido ao longo deste trabalho, o modelo da rede passou a ser predominante em diversos campos da sociedade, inclusive como paradigma da ação autônoma de grupos de resistência e busca de alternativas em escala global.

O Fórum Social Mundial insere-se nessa dinâmica e também funciona segundo a lógica de rede, oferecendo um espaço que estimula o encontro, as articulações, as atividades conjuntas entre indivíduos e grupos, a troca de experiências de uma maneira fluida, flexível e de acordo com o objetivo e o desejo de seus participantes em cada momento e não seguindo determinações de uma autoridade ou centro de decisão.

De um modo geral, as redes podem apresentar diferentes formatos e composições de acordo com as ações propostas. Elas podem ser formadas por diferentes participantes segundo cada situação, ou seja, não há uma configuração fixa e, sim, uma aproximação e união dos atores para uma ação comum de acordo com o interesse dos participantes. É uma lógica que privilegia a autonomia, a não diretividade e a abertura para diversas possibilidades. Cada ponto da rede pode se conectar com outros pontos quando e se assim desejar.

Ao contrário de organizações estruturadas de maneira tradicional, onde os membros formam uma estrutura uniforme e adotam posições comuns, podendo se manifestar em nome da organização, as redes apresentam uma lógica bastante diferente, de descentralização, de pluralidade de participantes e de posicionamentos. Enquanto para as organizações tradicionais, a lógica era "unificar as posições para poder apresentá-las com a força da totalidade dos membros" (ORTELLADO; RYOKI, 2004, p. 17), atualmente a autonomia e a 
diversidade presentes na lógica da rede e nas novas formas de atuação e coabitação são os pontos fortes que garantem a força e a união dos membros.

Redes não são organismos com uma estrutura organizacional definida ou com posições uniformes - elas são flexíveis, fluidas, plurais e descentralizadas. Redes são uma forma relativamente nova de associação, na qual as "partes" (indivíduos, organizações ou outras redes) se unem para perseguir objetivos específicos respeitando apenas princípios gerais acordados. Dessa forma, as redes permitem a convivência e o trabalho comum de grupos e indivíduos bastante diferentes, que não precisam sacrificar suas posições particulares para atuarem em conjunto. (ORTELLADO; RYOKI, 2004, p. 17)

Além disso, pode-se observar que a estrutura em rede é não exclusiva, ou seja, permite a participação simultânea em outras redes e dificulta o estabelecimento de práticas hegemônicas, uma vez que a rede expressa frequentemente posições gerais e raramente posições ou declarações comuns, evitando a disputa pelas posições de destaque e decisão típicas das organizações tradicionais (ORTELLADO; RYOKI, 2004).

A ampla disseminação das tecnologias de informação e comunicação na década de 90 teve seu desenvolvimento atrelado e concomitante a essas novas formas de relação social e ao aumento das redes sociais. Como reforça Whitaker,

diferentemente de uma organização tradicional, ninguém pode falar em nome de uma rede. É uma estrutura horizontal cujos membros compartilham um objetivo ou uma carta de valores. Como numa rede não existe um centro de poder, não é a organização que define a ação de seus membros, mas a iniciativa dos seus membros que constitui a ação da rede. Nesse sentido, o Fórum Social Mundial é uma rede de redes. Essa forma de organização mantém um grande paralelismo com a web da Internet [...] Não é por acaso que a explosão da Internet e a emergência dessa nova maneira de se organizar são simultâneas. Elas resultam da mesma lógica. (WHITAKER, 2005, p. 99)

Recuperando alguns elementos anteriormente apresentados, é possível notar a existência desse paralelismo entre o contexto em que grupos autônomos de resistência à ordem dominante se desenvolveram e a utilização dos recursos oferecidos pelo desenvolvimento tecnológico. Tanto o movimento zapatista como a 
onda de protestos inaugurada com o episódio de Seattle tiveram como elemento intrínseco às suas ações o uso da internet para troca de informação, articulação e mobilização dos envolvidos, renovando a maneira de agir e de apresentar suas opiniões e propostas.

A dinâmica da rede é uma característica constituinte e marcante dos novos modos de atuação de indivíduos e coletivos. Como esclarecem Hardt e Negri,

\begin{abstract}
os movimentos de globalização que se estenderam de Seattle a Gênova e aos Fóruns Sociais Mundiais de Porto Alegre e Mumbai, mobilizando os movimentos contra a guerra, constituem o exemplo mais claro até hoje de organizações disseminadas em rede. Um dos elementos mais surpreendentes dos acontecimentos de Seattle em novembro de 1999 e em cada uma das grandes manifestações ocorridas desde então é o fato de que grupos que até então considerávamos diferentes e até contraditórios em seus interesses agiam em comum - ambientalistas com sindicalistas, anarquistas com grupos religiosos, gays e lésbicas com os que protestavam contra o complexo carcerário-industrial. Os grupos não se apresentam unidos sob qualquer autoridade única, antes se relacionando numa estrutura em rede. Os fóruns sociais, os grupos de afinidade e outras formas de processos decisórios democráticos constituem a base desses movimentos, que conseguem agir conjuntamente de acordo com o que têm em comum. Por isto é que se denominam "movimento dos movimentos". A plena expressão da autonomia e da diferença de cada um coincide aqui com a poderosa articulação de todos. A democracia define tanto a meta dos movimentos quanto sua constante atividade. (HARDT; NEGRI, 2005b, p. 125).
\end{abstract}

Em uma análise sobre o Fórum Social Mundial e o modelo em rede, Christophe Aguiton busca compreender qual solução organizacional é mais conveniente atualmente ao chamado movimento altermundialista. O autor questiona qual seria a forma de coordenação que essas múltiplas redes de associações, movimentos sociais, ONGs e outros coletivos poderiam adotar para favorecer as formas de ação coletiva de caráter internacional, preservando a diversidade de seus componentes. Para Aguiton, o movimento altermundialista se expressa através de um sistema de coordenação de caráter reticular e horizontal, adotando uma forma 
com uma série de inovações organizacionais, sendo a mais original a criação do processo Fórum Social Mundial.

Da mesma forma que as empresas hierárquicas, criticadas por seu modelo vertical e centralizado, mudaram seu tipo de organização, adotando um caráter horizontal e descentralizado típico da forma em rede, alguns setores militantes provocaram o surgimento de coletivos também baseados na forma em rede, incorporando as formas reticulares como oposição à burocracia partidária ou sindical. As redes técnicas estão fortemente ligadas a essa evolução, principalmente através do desenvolvimento dos sistemas de comunicação da internet, com sua infra-estrutura descentralizada e cooperativa.

O que o autor denomina como "forma rede" ("forme réseau") revelou-se uma componente poderosa e eficaz dos modos de relação entre militantes e organizações que surgiram no início dos anos 90. A "forma rede", para o autor, é entendida como

les dispositifs organisationnels qui se caractérisent par un faible étagement hiérarchique, une structure décentralisée laissant une importante marge d'autonomie aux acteurs, la recherche de coordination avec d'autres entités extérieures et le souci du consensus dans les prises de décision. (AGUITON; CARDON, 2005 p. 2). ${ }^{25}$

Tendo em vista que a horizontalidade é a componente principal da forma organizacional reticular, frequentemente os atores atribuem a essa forma valores que a associam às culturas participativas, tais como flexibilidade, mobilidade, respeito às individualidades, maior ênfase na ação etc.

Même si, à l'évidence, l'ensemble des collectifs (associations, ONG, syndicats, mouvements sociaux, think tank, fondations, églises) qui se reconnaissent aujourd'hui dans le mouvement altermondialiste

\footnotetext{
${ }^{25}$ os dispositivos organizacionais que se caracterizam por uma condição hierárquica de baixa intensidade, uma estrutura descentralizada que deixa uma importante margem de autonomia aos atores, a busca de coordenação em conjunto com outras entidades e a preocupação em adotar o consenso como procedimento de tomada de decisão.
} 
présentent des structures organisationnelles extrêmement hétérogènes, et souvent très éloignées de la visée d'horizontalité à laquelle prétend la "forme réseau », cette exigence fait cependant l'objet d'une valorisation collective comme principe de coordination désirable pour les organisations elles-mêmes, mais surtout pour le tissu qu'elles forment en se retrouvant au sein des forums sociaux. (AGUITON; CARDON, 2005, p. 3) ${ }^{26}$

O autor observa que o aparecimento da "forma rede" como forma de coordenação privilegiada pelas organizações de cunho internacional acompanha as transformações dos modos de envolvimento individual, que passaram a ser mais móveis, mais específicos e mais individuais também.

Além disso, o formato da rede não permite a existência de um lado de fora de onde seria possível agir no sentido de totalizar as entidades da rede. A rede em si não constitui um coletivo, nem possui uma estrutura de representação capaz de orientar ações ou estratégias únicas e totalitárias. A forma em rede se apresenta como um meio instável de fluxo, intercâmbio e transações.

Aguiton desenvolve um pequeno modelo descritivo que permite visualizar a lógica interna das tensões que atravessam os debates do movimento altermundialista. Segundo o autor, a forma fórum, que tem como base a estrutura reticular, pode ser descrita como a implementação de um projeto com dois objetivos, a saber: produzir um espaço comum e favorecer a emergência de ações coletivas.

O primeiro objetivo teria uma "vocação socializadora", uma vez que pretende produzir um espaço comum de encontro para expor e debater diferentes temas de participantes envolvidos em diversas experiências e práticas. Assim, os fóruns constituem um local aberto à participação, à formação de projetos conjuntos e à

\footnotetext{
${ }^{26}$ Mesmo se, evidentemente, o conjunto dos coletivos (associações, ONG, sindicatos, movimentos sociais, think tank, fundações, igrejas) que se reconhecem hoje no movimento altermundialista apresentam estruturas organizacionais extremamente heterogêneas e, com frequência, bastante distantes da aspirada horizontalidade pretendida pela "forma rede", essa exigência, no entanto, se torna objeto de uma valorização coletiva como princípio de coordenação desejável para as próprias organizações, mas, sobretudo, para o tecido que elas formam ao se encontrar no seio dos fóruns sociais.
} 
articulação dos atores. Essa tendência é mais pluralista e enfatiza a diversidade dos posicionamentos. O segundo objetivo apresentaria uma "vocação mobilizadora", ao se propor como local de emergência e afirmação de estratégias de ação coletiva, reunindo os participantes para ações conjuntas (campanhas, chamados etc). Nessa perspectiva, os fóruns se apresentam como locais de convergência de mobilizações e de geração de novas lutas. Essa tendência insiste na necessidade de uma condução coletiva dos chamados de mobilização.

O autor observa que essa dualidade existe desde as primeiras formas de coordenação coletiva que apareceram com os movimentos altermundialistas. Essas duas polaridades na definição do projeto dos fóruns sociais geram um debate presente desde sua primeira edição que divide opiniões em torno da oposição entre um "fórum espaço" (no caso do objetivo que favorece a produção de um espaço comum) e um "fórum movimento" (no caso da emergência de ações coletivas promovidas por uma coordenação).

Ainda segundo esse modelo, a forma fórum segue três princípios de horizontalidade próprios à "forma rede". O primeiro é a ampliação das conexões em direção a novos atores, ou seja, a diversidade é entendida como qualidade e não como dificuldade. Esse princípio favorece a abertura e a extensão máxima da rede de participantes. O segundo é a recusa da delegação e da centralidade, isto é, os fóruns sociais não possuem um porta-voz nem assinam um documento final, então ninguém está dotado de poder para falar em nome do fórum. Esse princípio garante a multiplicidade e a diversidade de opiniões, posicionamentos e ações. O terceiro princípio é a adoção do consenso como procedimento de tomada de decisão, adotado como única forma desejável em um espaço de coordenação que reúne organizações heterogêneas. 
Através da apresentação desse modelo, o autor pretende nos mostrar as linhas de tensão que surgem da confrontação entre o projeto dos fóruns sociais e os princípios de horizontalidade da "forma rede". Adotando um olhar crítico, ele afirma que nem sempre a realidade das práticas organizacionais segue essa descrição abstrata da arquitetura dos fóruns. A solução proposta pelo autor é que as organizações e os atores que participam do processo fórum em diversas instâncias tenham em mente esses princípios de horizontalidade para medir até que ponto se pode observar uma aplicação prática desses princípios constitutivos do mundo em rede e como é possível se aproximar cada vez mais desse modelo, já que todos são responsáveis por sua construção.

Nesse sentido, os modos de coordenação das instâncias organizativas e a metodologia dos fóruns sofreram grandes transformações desde sua primeira edição, em janeiro de 2001. É no sentido de uma radicalização dos princípios de funcionamento em rede que as escolhas metodológicas e organizativas vêm sendo realizadas pelos promotores dos fóruns sociais mundiais. Devido ao seu caráter de novidade e fluidez, a dinâmica dos fóruns é alterada de acordo com as tentativas e erros, com as críticas e contribuições internas e externas e com os novos elementos que modificam e configuram o contexto mundial. É uma dinâmica em constante transformação, que mescla elementos de coordenação tradicionais com soluções inovadoras, experimentais e radicais.

II ne fait pas de doute que les formes organisationnelles conçues par les promoteurs des forums sociaux ne font que reprendre des formes organisationnelles existantes, en s'efforçant de les généraliser à des coordinations internationales. Mais la participation à un espace autoorganisé constitue aussi une rupture importante pour nombre de traditions politiques qui participent aux activités des forums sociaux. (AGUITON;CARDON, 2005, p. 34). ${ }^{27}$

\footnotetext{
${ }^{27}$ Sem dúvida, as formas organizacionais concebidas pelos promotores dos fóruns sociais retomam as formas organizacionais existentes, fazendo um esforço para generalizá-las às coordenações internacionais. Mas a participação em um espaço auto-organizado também constitui uma ruptura
} 
Surgem na dinâmica do processo fórum iniciativas baseadas nas novas tecnologias e iniciativas de experimentação de um conjunto de práticas alternativas. Alguns destaques são: movimento em prol do software livre; grupos de mídia alternativa; rede de tradutores voluntários - Babels; rede de produção e organização de equipamentos de tradução - projeto Nomad; Acampamento Intercontinental da Juventude, uma verdadeira cidade experimentando práticas de autogestão e divisão de tarefas; propostas elaboradas para gestão do lixo e construção de espaços com materiais ecológicos.

Esses exemplos, entre tantos outros, permitem a vivência de uma nova forma de produzir e trocar conhecimento, de estabelecer relações baseadas em valores que estejam além do valor mercantil e de uma nova maneira de conceber a vida. São experimentos pontuais de formas alternativas de se viver e de atuar no mundo. Através dessas realizações temporárias, são criados espaços onde os envolvidos podem ampliar e fortalecer suas práticas construindo, a cada momento, as relações e o mundo onde se pretende viver.

O trabalho de Negri \& Hardt vem ao encontro dessas ideias quando afirma que

uma característica da luta em rede da multidão é que ocorre no terreno biopolítico - em outras palavras, ela produz diretamente novas subjetividades e novas formas de vida [...] seus valores fundamentais são a criatividade, a comunicação e a cooperação auto-organizada [...] cada vez mais o seu foco é interno - produzir novas subjetividades e novas formas expansivas de vida dentro da própria organização. (HARDT; NEGRI, 2005b, p. 121).

\section{CONSIDERAÇÕES FINAIS}

importante para diversas tradições políticas que participam das atividades dos fóruns sociais. 
Nos capítulos precedentes, procurou-se desenvolver, primeiramente, um panorama sobre o contexto de transformação do mundo moderno para o pósmoderno, relacionando-o com as vagas de inovação tecnológica. Com o desenvolvimento das tecnologias de informação e comunicação que marcaram o século XX, observa-se, atualmente, uma situação totalmente inédita, que modifica as relações do ser humano com os bens imateriais, como a informação e o conhecimento. Surgem novas práticas sociais e as relações passam a ser configuradas segundo o modelo de rede, ou seja, privilegia-se a forma rizomática, reticular, horizontal e descentralizada, em detrimento das estruturas verticais e centralizadas que predominavam em épocas passadas. O modelo da rede se torna presente nos mais diversos campos da vida e das sociedades, interferindo na atuação de empresas, no capital, na produção e distribuição do conhecimento, na produção e troca de bens culturais e artísticos e, consequentemente, modifica as relações sociais e o comportamento das pessoas.

Na ação política, ou melhor, biopolítica - já que "o político rapidamente se amalgama com o econômico, o social e o cultural” (HARDT; NEGRI, 2005b, p. 15), abrangendo e mesclando todos os aspectos da vida - também há uma mudança, que passa a vincular as pessoas em rede. No lugar de instituições formalmente organizadas e de membros seguidores de uma direção central, aparece um novo tipo de ação, onde a atuação de indivíduos e grupos baseia-se nos princípios de autonomia, fluidez e recusa a centros de poder. As diversas manifestações citadas na pesquisa e o Fórum Social Mundial podem ser entendidos como expressões dessa nova forma de resistência, que se articula fundamentalmente via internet. Assim como o poder, as resistências agem de forma desterritorializada, global e móvel. 
Os grupos de afinidade compõem a multidão de singularidades que tem manifestado sua oposição de maneira ampla e autônoma [...] Incluir é a palavra de ordem; igualdade como respeito às diferenças e como participação direta nas decisões e ações. A idéia de rede, de rizoma, é fundamental para a compreensão dessas intervenções. Uma nova forma de coabitação: descentralizada, plural, momentânea, flexível. (OLIVEIRA, 2007, p. 37)

A rede mundial de computadores, a internet, foi constituída de modo a permitir a liberdade de fluxos e conteúdos. Embora seja essa sua natureza, não faz sentido adotar um olhar parcial, considerando apenas sua dimensão libertária, pois como foi analisado, ela também revela uma dimensão que pode reforçar o controle, a dominação, a propagação de comportamentos preconceituosos e o predomínio de relações puramente comerciais. Como esclarece Sérgio Amadeu,

\begin{abstract}
A rede está assegurando a expansão do compartilhamento do conhecimento e da produção cultural. Mas não podemos esquecer que o desenvolvimento e a evolução da rede são fruto de um embate cultural e ideológico que vem sendo apresentado como se fosse uma disputa tecnológica, neutra, de caráter estritamente técnico. Aí se manifesta toda a ambivalência da rede, em que sua trajetória opõe e apresenta no mínimo dois componentes antagônicos, simultâneos, que expressam valores e objetivos distintos. Um quer aprofundar a liberdade de fluxos e a produção do comum, ou seja, ampliar os espaços públicos, a liberdade e o domínio público, seja no uso seja na evolução tecnológica da rede. O outro quer contê-la em um processo econômico baseado na apropriação privada do conhecimento, dos bens imateriais e dos espaços por onde transitam os fluxos. (SILVEIRA, 2007, p. 26)
\end{abstract}

Essa pesquisa, em vez de apresentar respostas, busca oferecer reflexões no sentido de como é possível potencializar o uso das redes; como usufruir melhor os recursos existentes para fortalecer seu aspecto colaborativo, participativo e democrático; como tomar conhecimento de suas propriedades para promover através das redes mais liberdade, mais acesso à informação e ao conhecimento, mais articulação e mobilização para o fortalecimento das redes e a realização de ações comuns. 
Muitas análises contemporâneas destacam as profundas mudanças que vêm sendo observadas nas práticas sociais atualmente e apontam para a possibilidade de caminharmos em direção a novos rumos. Levando isso em consideração, o momento em que vivemos pode ser entendido como uma oportunidade para criarmos, de fato, novas relações, estabelecermos novos parâmetros e novos valores. Como reforça Benkler,

The reorganization of production and the advances it can bring in freedom and justice will emerge only as a result of social practices and political actions that successfully resist efforts to regulate the emergence of the networked information economy in order to minimize its impact on the incumbents. (BENKLER, 2006, parte 3, p. 2).$^{28}$

A relação estabelecida na pesquisa entre a configuração das relações em rede e o Fórum Social Mundial é uma tentativa de compreender o aparecimento e a força do Fórum como expressão dessa busca coletiva de criar novas formas de vida; entendê-lo como um espaço de experimentação, criatividade e liberdade, algo que poderia expandir sua própria lógica para outros espaços da sociedade.

Através da comunicação via internet, o encontro mobiliza os participantes, envia informes, organiza as inscrições de atividades, em síntese, o papel da rede de computadores é parte intrínseca do processo Fórum. As tecnologias de informação e comunicação, evidentemente, não são as verdadeiras responsáveis pelas transformações nas relações e na sociedade, mas são parte integrante desse contexto de mudança. Há uma dinâmica conjunta de transformações culturais, com vários aspectos que se desenrolam paralelamente. O interessante é observar como esses processos estão caminhando; tentar entender quais são essas novas práticas e em quais direções elas estão apontando.

\footnotetext{
${ }^{28}$ A reorganização da produção e os avanços que ela pode trazer em termos de liberdade e justiça emergirá somente como um resultado de práticas sociais e ações políticas que resistam sucessivamente a esforços para regular a emergência da economia informacional em rede com o objetivo de minimizar seu impacto nos afetados.
} 
Examinando as iniciativas que privilegiam a ação autônoma e participativa, percebe-se de que forma elas se apropriam da nova configuração reticular e horizontal para promover suas ações; há um movimento constante, às vezes mais visível, outras vezes menos, que aproveita as brechas, que age e procura interferir no rumo dos acontecimentos e transformar o momento, a realidade. Essas reflexões nos permitem perceber melhor o mundo, compreender o que está em jogo e como podemos atuar; quais escolhas podemos fazer se queremos viver em uma sociedade mais livre e democrática.

Um aspecto interessante a ser destacado é em relação ao papel de intermediário que cumpre o Fórum Social Mundial. Ele oferece espaço e cria possibilidades para que aconteçam os encontros, as articulações, as atividades, a troca de experiência. O FSM exerce uma mediação crítica e ativa, que estimula questionamentos e mudanças. O processo Fórum está sendo sempre revisto, analisado, discutido. O formato e a metodologia dos encontros estão constantemente sofrendo alterações, dando novos rumos ao processo e incentivando sempre uma participação mais ampla, aberta e autônoma dos indivíduos e coletivos participantes.

O fato de o Fórum ser realizado em locais como Mumbai (Índia), Bamako, Nairobi (África) ou Belém (Brasil) mostra o que, muitas vezes, o mundo não quer ver; sua presença incomoda, revela as contradições em que vivemos. Esses confrontos são importantes, pois nos permitem encarar as escolhas que têm sido feitas e que moldam as sociedades e as relações que temos hoje.

O fato de ser em Belém, por exemplo, relembra o problema global da crise ambiental, mas destaca, sobretudo, os problemas locais, como os conflitos de terra, 
étnicos, de biopirataria, de devastação da floresta, de violência urbana; em síntese, expõe globalmente o local que a muitos não convém discutir.

O Acampamento Intercontinental da Juventude também é um exemplo interessante porque mostra uma nova geração que não deseja o modelo de sociedade que existe hoje, revela que há muitos em busca de outras formas de se relacionar com os outros e com a vida. As práticas propostas durante os encontros evidenciam a necessidade de se experimentar alternativas que superem os padrões de comportamento existentes.

Como um intermediário, uma interface, o Fórum abre espaço para o convívio da diversidade, possibilita a expressão de muitas vozes, permite que questões locais se ampliem, tornando-se discussões mundiais e deixa claro, ao mesmo tempo, que a dinâmica mundial afeta a vida das populações locais. Sua dinâmica nos lembra que tudo está interligado; que somos, de fato, vários nós da mesma rede.

Pode-se refletir também sobre o conceito de ação cultural que, segundo a definição da própria linha de pesquisa (mediação e ação cultural), é entendida como o "processo de criação ou organização das condições necessárias para que as pessoas e grupos inventem seus próprios fins no universo da cultura". ${ }^{29}$ Estudando o FSM e as redes, essa relação configuraria uma ação cultural? Uma vez que o formato do Fórum Social Mundial oferece as condições necessárias para que os participantes elaborem suas propostas e se articulem para implementar suas iniciativas coletivas rumo à construção de novas possibilidades de mundo, ele poderia ser compreendido como ação cultural?

\footnotetext{
${ }^{29}$ Informações obtidas no site da Escola de Comunicações e Artes da Universidade de São Paulo (ECA, USP): http://www.eca.usp.br/
} 
Outro elemento de reflexão baseia-se no fato de esta pesquisadora ter participado do Fórum Social Mundial de duas formas - como participante e como parte da equipe organizadora - o que propiciou um olhar duplo, a partir do lado de dentro e do lado de fora.

O intuito dessa pesquisa de mestrado não era fazer uma análise crítica do FSM, pois o escopo do trabalho se restringe à relação entre o paradigma de rede e o Fórum Social Mundial. Certamente, as críticas tanto em relação aos aspectos internos da organização quanto em relação aos aspectos externos, do ponto de vista dos participantes são de extrema relevância, tanto é que muitas mudanças no processo Fórum vieram dessas contribuições. Entretanto, como esse não era o objetivo dessa pesquisa, apenas alguns pontos mais controversos foram apresentados.

Do ponto de vista externo, em minha experiência como participante, a sensação marcante que tive em 2002 em Porto Alegre, antes de fazer parte da equipe organizadora e quando pouco sabia sobre o encontro, se repetiu em 2009 em Belém: o ânimo renovado, a recuperação da esperança e até uma certa euforia. O Fórum em si exerce esse poder sobre as pessoas; possui a capacidade de uni-las e, além disso, de desarmá-las, de estimular um comportamento aberto e receptivo frente ao diferente, ao novo. Todo o medo, a violência, a falta de perspectiva, o individualismo que parecem ser predominantes no mundo de hoje ficam suspensos; surge espaço para a comunicação descompromissada, desinteressada; para que cada um possa ser o que é, sem precisar seguir padrões para ser aceito. Nesse sentido, o Fórum seria um exemplo de como potencializar o uso da rede; um exemplo de como as relações em rede podem gerar resultados positivos, possibilitando o encontro de pessoas de todo o mundo, estimulando o trabalho em 
conjunto, criando a oportunidade de entrar em contato com novas culturas e visões de mundo. Um exercício interessante é pensar em como ampliar a experiência do fórum para outros contextos da própria vida.

No evento de 2002, o caráter de novidade, o encontro das diferenças, a possibilidade de compartilhar inquietações com pessoas de outros lugares e contextos e a descoberta de realidades até então inexistentes para mim foram os aspectos que mais me chamaram a atenção.

Em 2009, o Fórum em si já não se destacou por ser uma novidade, mas alguns pontos reforçaram a relevância do encontro, entre eles: o fato de um evento desse porte ser realizado com a dificuldade da infra-estrutura e da dinâmica das relações locais; pela primeira vez houve uma participação mais expressiva de povos indígenas do Brasil e da região dos Andes e dos chamados "povos e nações sem Estado" (catalão, basco, curdo, palestino, entre tantos outros); o contexto da crise mundial reafirmando a indispensabilidade de uma série de discussões e a importância do Fórum como espaço para tal.

Na nona edição do encontro, reflexões acerca de seu desenvolvimento desde a primeira edição pareceram bastante apropriadas. Em uma atividade ${ }^{30}$, sobre os princípios e práticas que constituíram o FSM desde o início, Amit (2009) questiona a composição dos grupos responsáveis pela organização dos Fóruns, afirmando que há uma contradição difícil de se lidar, já que a diversidade presente no Fórum não é representada no âmbito da organização. Ele levanta a necessidade de se trabalhar

\footnotetext{
${ }^{30}$ A atividade Critically engaging with the Principles underlying the World Social Forum (Abordando criticamente os princípios subjacentes ao Fórum Social Mundial) foi realizada em 29/01/09, na Universidade Federal do Pará (UFPA), pela organização CACIM (India Institute for Critical Action: Centre In Movement), durante o FSM 2009, em Belém.
} 
com estruturas o mais horizontais possíveis, que consigam minimizar essa contradição (informação verbal). ${ }^{31}$

Na mesma atividade, a palestrante Silvia (2009) aponta que a dificuldade é a diversidade dos movimentos que apresentam princípios bastante diversificados, muitas vezes diferentes dos próprios princípios do FSM, onde culturas políticas muito diferentes se encontram (algumas tradicionais e centralizadas e outras praticamente anárquicas). Essas dimensões estão presentes nas instâncias organizativas também, tanto no Conselho Internacional como em âmbito local e são constantes no desenvolvimento do FSM. Em sua opinião, os princípios do Fórum Social Mundial são mais avançados do que a própria prática política dos participantes. Em sua exposição, ela ainda afirma que vê o FSM como um processo que mantém grupos e ações globais articulados e, nesse sentido, ele contribui para os movimentos que estavam à margem, trazendo-os para o centro das discussões com outros movimentos (informação pessoal). ${ }^{32}$

Outro palestrante, Raphael (2009), sustenta que não se deve reduzir a discussão ao entendimento dicotômico do FSM como processo ou evento, como espaço aberto ou movimento, mas vê-lo como uma experiência que contribui criando novas culturas políticas. Para ele, a ideia de espaço aberto é algo que está sendo construído e como garantirmos essa abertura é o ponto central sobre o qual devemos pensar. Ele destaca uma ação que surgiu durante o FSM 2009 como exemplo de seu caráter de espaço aberto, que favorece o surgimento de diálogos e

\footnotetext{
${ }^{31}$ Informação fornecida por Amit Sengupta (Secretário-Geral, All India People's Science Network, e membro do IWC do FSM Índia), na atividade Critically engaging with the Principles underlying the World Social Forum (Abordando criticamente os princípios subjacentes ao Fórum Social Mundial), em 29/01/09, durante o FSM 2009, em Belém.

32 Informação fornecida por Silvia Camurga (Articulação de Mulheres Brasileiras (AMB) \& Articulación Feminista Marco Sur, Brasil), na atividade Critically engaging with the Principles underlying the World Social Forum (Abordando criticamente os princípios subjacentes ao Fórum Social Mundial), em 29/01/09, durante o FSM 2009, em Belém.
} 
articulações: povos indígenas de diversas regiões definiram uma mobilização continental para o dia 12 de outubro, dia da Pacha Mama (Mãe Terra) (informação pessoal). ${ }^{33}$ Um outro exemplo é o calendário de mobilizações que resultou da sistematização das conclusões de diversas atividades realizadas.

A diversidade realmente chama a atenção e é uma das grandes riquezas do FSM. No seio da imensa variedade temática do evento, outra atividade interessante ${ }^{34}$ era formada por diversos palestrantes que relatavam suas pesquisas em torno do tema movimentos sociais. As apresentações eram bastante diversificadas, incluindo assuntos como: movimento antiglobalização; um estudo de caso sobre a atuação das redes; resultados de campanhas propostas e até a influência do Fórum Social Mundial em um núcleo de pesquisa de uma universidade paulista.

Do ponto de vista interno, de quem atuou no escritório executivo do Fórum Social Mundial, na cidade de São Paulo, é possível afirmar que o espírito do evento esteve frequentemente presente. Principalmente nas atividades do dia a dia do escritório, em minha experiência, a coerência entre os princípios e as ações, o comportamento colaborativo, aberto, inovador e um envolvimento genuíno da equipe eram fatores motivadores determinantes.

Quando se amplia o olhar em direção a outras instâncias organizadoras (não apenas o escritório onde eu executava minhas atividades), é claro que, sendo um evento de grandes proporções que segue uma dinâmica mais aberta de participação

\footnotetext{
33 Informação fornecida por Raphael Hoetmer (Diretor-Adjunto do Programa de Estudos sobre Democracia e Transformação Global, Universidad Nacional Mayor de San Marcos, Lima, Peru), na atividade Critically engaging with the Principles underlying the World Social Forum (Abordando criticamente os princípios subjacentes ao Fórum Social Mundial), em 29/01/09, durante o FSM 2009, em Belém.

${ }^{34}$ A atividade Movimentos sociais: entre as experiências e a construção de pensamento crítico foi realizada em 29/01/09, na Universidade Federal do Pará (UFPA), pela organização $R C-47$ da Associação Internacional de Sociologia, durante o FSM 2009, em Belém.
} 
e decisão, o funcionamento desse conjunto nem sempre acontece muito harmoniosamente. Essa dificuldade é acentuada de acordo com o contexto e a relação entre as entidades organizadoras de cada local onde o Fórum é realizado. É sempre uma experiência enriquecedora, mas nem sempre fácil.

Como o Fórum surgiu como algo novo, as tensões estão presentes na relação entre velhas formas e práticas emergentes, experimentais, inovadoras. Nas relações, por vezes há disputa de poder e as velhas e novas práticas, gerações e concepções estão constantemente se confrontando. Como se sabe, é lento e trabalhoso abandonar velhos modelos e agir de acordo com novos princípios estabelecidos. São mudanças que levam tempo para serem realmente efetivadas e incorporadas na ação individual e coletiva. Acima das dificuldades e contradições, o fundamental é que esse diálogo esteja presente, que novas práticas sejam propostas e experimentadas.

As reflexões aqui apresentadas não têm o intuito de constituir uma conclusão sobre o tema pesquisado mas, sim, de levantar novas questões e de fornecer elementos para que muitos dos assuntos sejam repensados. Como o objeto da pesquisa é contemporâneo, ele está em constante transformação e aberto para novos olhares; espera-se, desse modo, que o estudo possa contribuir, ampliando a discussão sobre o assunto. Procurou-se apresentar aqui um recorte sobre o tema das redes e sua relação com o Fórum Social Mundial; investigar como se constitui o mundo das redes; quais as recentes transformações socioculturais mais marcantes; o que se destaca em termos dos movimentos de resistência e como se articulam as ações no final do século XX e XXI. Compreendendo esses fenômenos, é possível pensar em como podemos também interferir e transformar nossas relações com a vida e com o mundo. 


\section{REFERÊNCIAS BIBLIOGRÁFICAS}

AGUITON, Christophe. Le Forum et le Réseau. Une analyse des modes de gouvernement des forums sociaux. In: COLLOQUE CULTURES ET PRATIQUES PARTICIPATIVES: UNE PERSPECTIVE COMPARATIVE - LAIOS/AFSP, 2005. Disponível em: <http://mokk.bme.hu/centre/conferences/reactivism/conferencepanels/global>. Acesso em: 27 jun. 2008.

BARRIOS, Elizabeth Pólito; ESPONDA, Juan González. Notas para comprender el origen de la rebelión zapatista. Revista Chiapas, v. 1, 1995. Disponível em: < $\underline{\text { http:// }}$ membres.lycos.fr/revistachiapas/>. Acesso em: 12 mai. 2009.

BAUMAN, Zygmunt. Globalização: as consequências humanas. Rio de Janeiro: Jorge Zahar Ed, 1999.

. Modernidade Líquida. Rio de Janeiro: Jorge Zahar Ed, 2001.

BENKLER, Yochai. The Wealth of Networks: How Social Production Transforms Markets and Freedom. Yale University Press: 2006. Disponível em:

$<$ http://cyber.law.harvard.edu/wealth_of_networks/Main_Page >. Acesso em: 01 jul. 2007.

BURKE, Peter. Uma história social do conhecimento: de Gutenberg a Diderot. Rio de Janeiro: Jorge Zahar Ed, 2003.

Uma história social da mídia: de Gutenberg à Internet. 2. ed. rev. e ampl. Rio de Janeiro: Jorge Zahar Ed., 2006.

CAROS AMIGOS. São Paulo: Editora Casa Amarela, ano XII, n. 46, abr. 2009. Número especial.

CASTELLS, Manuel. A Sociedade em Rede. 9. ed. rev. e ampl. São Paulo: Paz e Terra, 1999.

. Communication, power and Counter-power in the Network Society.

Internacional Journal of Communication 1 (2007), 238-266. Disponível em: <http://ijoc.org/ojs/index.php/ijoc/article/view/46/35>. Acesso em: 06 nov. 2007.

CECEÑA, Ana Esther. La resistencia como espacio de construcción del nuevo mundo. Revista Chiapas, v. 7, 1999. Disponível em:

<http://membres.lycos.fr/revistachiapas/>. Acesso em: 12 mai. 2009.

COELHO, Teixeira. O que é ação cultural. São Paulo: Brasiliense, 1989.

. Dicionário Crítico de Política Cultural - Cultura e Imaginário. 3. ed. São Paulo: lluminuras, 2004.

2005.

Moderno pós moderno: modos \& versões. 5. ed. São Paulo: lluminuras, 
DELEUZE, Gilles; GUATTARI, Félix. Mil Platôs - capitalismo e esquizofrenia, v. 1. Rio de Janeiro: Ed. 34, 1995.

FREEMAN, Chistopher; LOUÇÃ, Francisco. As time goes by: the information revolution and the industrial revolutions in historical perspective. Oxford University Press, 2001.

FÓRUM OUTRO MUNDO EM DEBATE. São Paulo: Editora Publisher Brasil, n. 46, jan. 2007, n. 71, fev. 2009.

GALLOWAY, Alexander R. Global networks and effects on culture. The Annals, January, 2005.

GUEDES, José Paulo; LEITE, José Correa. Para além do valor: lógica das redes e racionalidade ambiental no mercado e contra o mercado. São Paulo, 2007.

Disponível em: < http://www.aepidemia.org/blog> . Acesso em: 11 jul. 2008.

HARDT, Michael; NEGRI, Antonio. A produção biopolítica. In: PARENTE, André (org.). Tramas da rede: novas dimensões filosóficas, estéticas e políticas da comunicação. Editora Sulina, 2004. 304 p.

. Império. 7. ed. Rio de Janeiro: Record, 2005a.

Multidão. Rio de Janeiro: Record, 2005b.

HARVEY, David. Condição pós-moderna: Uma Pesquisa sobre as Origens da Mudança Cultural. 10. ed. São Paulo: Edições Loyola, 2001.

HOLLOWAY, John. La resonancia del zapatismo. Revista Chiapas, v. 3, 1996.

Disponível em: <http://membres.lycos.fr/revistachiapas/>. Acesso em: 12 mai. 2009.

. Mudar o mundo sem tomar o poder. São Paulo: Boitempo Editorial, 2003.

KEANE, John. Transformações estruturais da esfera pública. In: Comunicação \& política. 1997.

KELLNER, Douglas. Techno-Politics New Technologies and the New Public Spheres. Disponível em: < http://www.gseis.ucla.edu/faculty/kellner/essays.html>. Acesso em: 11 jul. 2008.

KUMAR, Krishan. Da Sociedade Pós-Industrial à Pós-Moderna: novas teorias sobre o mundo contemporâneo. Rio de Janeiro: Jorge Zahar Editor, 1992.

LEITE, José Corrêa. Fórum Social Mundial: A história de uma invenção política. São Paulo: Editora Fundação Perseu Abramo, 2003.

As invenções da política - Sobre a existência da política e suas transformações. 2005. Tese (Doutorado). Pontifícia Universidade Católica de São Paulo - PUC, São Paulo. Cap. VI. 
. Revolução tecnológica e mutação no conhecimento. São Paulo, 2007a. Disponível em: < http://www.aepidemia.org/blog> . Acesso em: 27 jun. 2008.

. Convergência digital, internet e conhecimento livre. São Paulo, 2007b. Disponível em: < http://www.aepidemia.org/blog> . Acesso em: 11 jul. 2008.

LUDD, Ned (org.). Urgência das ruas: Black Block, Reclaim the Streets e os Dias de Ação Global. São Paulo: Conrad Editora do Brasil, 2002.

MUSSO, Pierre. A filosofia da rede. In: PARENTE, André (org.). Tramas da rede: novas dimensões filosóficas, estéticas e políticas da comunicação. Editora Sulina, 2004. 304 p.

NEGRI, Antônio. Infinitude da Comunicação/Finitude do Desejo. In; Parente, A. (org.). Imagem - Máquina: A Era das Tecnologias do Virtual. Rio de Janeiro: Editora 34, 1993.

OLIVEIRA, Lúcia Maciel Barbosa de. Corpos indisciplinados - ação cultural em tempos de biopolítica. São Paulo: Editora Beca, 2007.

ORTELLADO, Pablo; RYOKI, André. Estamos vencendo!: resistência global no Brasil. São Paulo: Conrad Editora do Brasil, 2004.

PARENTE, André. Enredando o pensamento: redes de transformação e subjetividade. In: PARENTE, André (org.). Tramas da rede: novas dimensões filosóficas, estéticas e políticas da comunicação. Editora Sulina, 2004. 304 p. $\overline{\text { Editora }}$ 34, 1994.

. Imagem-máquina: a era das tecnologias do virtual. Rio de Janeiro:

PARSONS, Claudia. Ódio se torna viral em sites de redes sociais-relatório.

Reuters/ Yahoo NOTícIAS, 13 mai. 2009. Disponível em:

$<$ http://br.tecnologia.yahoo.com/article/13052009/5/noticias-tecnologia-odio-se-tornaviral.html>. Acesso em: 13 mai. 2009.

PEDROLETTI, Brice. A explosão da Internet na China é um desafio para as autoridades. Le Monde, 30 jul. 2008. Disponível em:

<http://noticias.uol.com.br/midiaglobal/lemonde/2008/07/30/ult580u3221.jhtm>. Acesso em: 30 jul. 2008.

PRETTO, Nelson De Luca; SILVEIRA, Sérgio Amadeu da (orgs.). Além das redes de colaboração: internet, diversidade cultural e tecnologias do poder. Salvador: EDUFBA, 2008.

SANTOS, Boaventura de Sousa. O Fórum Social Mundial: manual de uso. São Paulo: Cortez, 2005.

SILVEIRA, Sergio Amadeu da. A mobilização colaborativa e a teoria da propriedade do bem intangível. 2005, 167 p. Tese (Doutorado). Faculdade de 
Filosofia, Letras e Ciências Humanas da Universidade de São Paulo - FFLCH/ USP, São Paulo.

SILVEIRA, Sergio Amadeu da et al. Comunicação digital e a construção dos commons: redes virais, espectro aberto e as novas possibilidades de regulação. São Paulo: Editora Fundação Perseu Abramo, 2007.

SOUSA, Ana Paula; PINHEIRO, Daniel; ATHAYDE, Phydia. O Brasil cai na rede. Carta Capital, São Paulo, n. 508, p. 28-34, 13 ago. 2008.

TAPSCOTT, Don; WILLIAMS, Anthony D. Wikinomics: como a colaboração em massa pode mudar seu negócio. Rio de Janeiro: Nova Fronteira, 2007.

WHITAKER, Chico. O desafio do Fórum Social Mundial: um modo de ver. São Paulo: Edições Loyola, 2005.

SITES:

Ação Global dos Povos (Dias de Ação Global) - http://www.nadir.org

Centro de Mídia Independente (CMI) - http://www.midiaindependente.org

Ciranda: http://www.ciranda.net/

Current TV - http://current.com/

Fórum Permanente - http://forumpermanente.incubadora.fapesp.br

Fórum Social Mundial - http://www.forumsocialmundial.org.br/

Jornal Epidemia - http://www.aepidemia.org/blog

Libcom - http://libcom.org/

Mídia Tática - http://www.midiatatica.org/

Museu de Arte Contemporânea da USP (MAC) - http://www.macvirtual.usp.br

Next 5 minutes - http://www.next5minutes.org

Overmundo - http://www.overmundo.com.br

Reclaim the streets - http://rts.gn.apc.org/

Revista Chiapas - http://membres.lycos.fr/revistachiapas

Wikipedia - http://pt.wikipedia.org 
ANEXOS 


\section{ANEXO A - Carta de Princípios do Fórum Social Mundial ${ }^{35}$}

O Comitê de entidades brasileiras que idealizou e organizou o primeiro Fórum Social Mundial, realizado em Porto Alegre de 25 a 30 de janeiro de 2001, considera necessário e legítimo, após avaliar os resultados desse Fórum e as expectativas que criou, estabelecer uma Carta de Princípios que oriente a continuidade dessa iniciativa. Os Princípios contidos na Carta, a ser respeitada por tod@s que queiram participar desse processo e organizar novas edições do Fórum Social Mundial, consolidam as decisões que presidiram a realização do Fórum de Porto Alegre e asseguraram seu êxito, e ampliam seu alcance, definindo orientações que decorrem da lógica dessas decisões.

1. O Fórum Social Mundial é um espaço aberto de encontro para o aprofundamento da reflexão, o debate democrático de idéias, a formulação de propostas, a troca livre de experiências e a articulação para ações eficazes, de entidades e movimentos da sociedade civil que se opõem ao neoliberalismo e ao domínio do mundo pelo capital e por qualquer forma de imperialismo, e estão empenhadas na construção de uma sociedade planetária orientada a uma relação fecunda entre os seres humanos e destes com a Terra.

2. O Fórum Social Mundial de Porto Alegre foi um evento localizado no tempo e no espaço. A partir de agora, na certeza proclamada em Porto Alegre de que "um outro mundo é possível", ele se torna um processo permanente de busca e construção de alternativas, que não se reduz aos eventos em que se apóie.

3. O Fórum Social Mundial é um processo de caráter mundial. Todos os encontros que se realizem como parte desse processo têm dimensão internacional.

4. As alternativas propostas no Fórum Social Mundial contrapõem-se a um processo de globalização comandado pelas grandes corporações multinacionais e pelos governos e instituições internacionais a serviço de seus interesses, com a cumplicidade de governos nacionais. Elas visam fazer prevalecer, como uma nova etapa da história do mundo, uma globalização solidária que respeite os direitos humanos universais, bem como os de tod@s @s cidadãos e cidadãs em todas as nações e o meio ambiente, apoiada em sistemas e instituições internacionais democráticos a serviço da justiça social, da igualdade e da soberania dos povos.

5. O Fórum Social Mundial reúne e articula somente entidades e movimentos da sociedade civil de todos os países do mundo, mas não pretende ser uma instância representativa da sociedade civil mundial.

6. Os encontros do Fórum Social Mundial não têm caráter deliberativo enquanto Fórum Social Mundial. Ninguém estará, portanto autorizado a exprimir, em nome do Fórum, em qualquer de suas edições, posições que pretenderiam ser de tod@s @s seus/suas participantes. @s participantes não devem ser chamad@s a tomar decisões, por voto ou aclamação, enquanto conjunto de participantes do Fórum, sobre declarações ou propostas de ação que @s engajem a tod@s ou à sua maioria e que se proponham a ser tomadas de posição do Fórum enquanto Fórum. Ele não

\footnotetext{
${ }^{35}$ Documento obtido no site do Fórum Social Mundial (http://www.forumsocialmundial.org.br), no link: http://www.forumsocialmundial.org.br/main.php?id_menu=4\&cd_language=1
} 
se constitui portanto em instancia de poder, a ser disputado pelos participantes de seus encontros, nem pretende se constituir em única alternativa de articulação e ação das entidades e movimentos que dele participem.

7. Deve ser, no entanto, assegurada, a entidades ou conjuntos de entidades que participem dos encontros do Fórum, a liberdade de deliberar, durante os mesmos, sobre declarações e ações que decidam desenvolver, isoladamente ou de forma articulada com outros participantes. O Fórum Social Mundial se compromete a difundir amplamente essas decisões, pelos meios ao seu alcance, sem direcionamentos, hierarquizações, censuras e restrições, mas como deliberações das entidades ou conjuntos de entidades que as tenham assumido.

8. O Fórum Social Mundial é um espaço plural e diversificado, não confessional, não governamental e não partidário, que articula de forma descentralizada, em rede, entidades e movimentos engajados em ações concretas, do nível local ao internacional, pela construção de um outro mundo.

9. O Fórum Social Mundial será sempre um espaço aberto ao pluralismo e à diversidade de engajamentos e atuações das entidades e movimentos que dele decidam participar, bem como à diversidade de gênero, etnias, culturas, gerações e capacidades físicas, desde que respeitem esta Carta de Princípios. Não deverão participar do Fórum representações partidárias nem organizações militares. Poderão ser convidados a participar, em caráter pessoal, governantes e parlamentares que assumam os compromissos desta Carta.

10. O Fórum Social Mundial se opõe a toda visão totalitária e reducionista da economia, do desenvolvimento e da história e ao uso da violência como meio de controle social pelo Estado. Propugna pelo respeito aos Direitos Humanos, pela prática de uma democracia verdadeira, participativa, por relações igualitárias, solidárias e pacíficas entre pessoas, etnias, gêneros e povos, condenando todas as formas de dominação assim como a sujeição de um ser humano pelo outro.

11. O Fórum Social Mundial, como espaço de debates, é um movimento de idéias que estimula a reflexão, e a disseminação transparente dos resultados dessa reflexão, sobre os mecanismos e instrumentos da dominação do capital, sobre os meios e ações de resistência e superação dessa dominação, sobre as alternativas propostas para resolver os problemas de exclusão e desigualdade social que o processo de globalização capitalista, com suas dimensões racistas, sexistas e destruidoras do meio ambiente está criando, internacionalmente e no interior dos países.

12. O Fórum Social Mundial, como espaço de troca de experiências, estimula o conhecimento e o reconhecimento mútuo das entidades e movimentos que dele participam, valorizando seu intercâmbio, especialmente o que a sociedade está construindo para centrar a atividade econômica e a ação política no atendimento das necessidades do ser humano e no respeito à natureza, no presente e para as futuras gerações.

13. O Fórum Social Mundial, como espaço de articulação, procura fortalecer e criar novas articulações nacionais e internacionais entre entidades e movimentos da 
sociedade, que aumentem, tanto na esfera da vida pública como da vida privada, a capacidade de resistência social não violenta ao processo de desumanização que o mundo está vivendo e à violência usada pelo Estado, e reforcem as iniciativas humanizadoras em curso pela ação desses movimentos e entidades.

14. O Fórum Social Mundial é um processo que estimula as entidades e movimentos que dele participam a situar suas ações, do nível local ao nacional e buscando uma participação ativa nas instâncias internacionais, como questões de cidadania planetária, introduzindo na agenda global as práticas transformadoras que estejam experimentando na construção de um mundo novo solidário.

Aprovada e adotada em São Paulo, em 9 de abril de 2001, pelas entidades que constituem o Comitê de Organização do Fórum Social Mundial, aprovada com modificações pelo Conselho Internacional do Fórum Social Mundial no dia 10 de junho de 2001. 
ANEXO B - Composição do Conselho Internacional do Fórum Social Mundial ${ }^{36}$ DELEGADOS

50 Years is Enough!

50years@50years.org; www.50years.org

ABONG - Associação Brasileira de ONGs

abong@uol.com.br; www.abong.org.br

Action Aid International - AAI

mail.jhb@actionaid.org; www.actionaid.org

ACTU - Australian Council of Trade Unions

mailbox@actu.asn.au; www.actu.asn.au

AFL-CIO - American Federation of Labor-Congress of Industrial Organizations feedback@aflcio.org; www.aflcio.org/home.htm

Africa Trade Network

aidc@iafrica.com; http://africatradenetwork.com

AIDC - Alternative Information on Development Center

aidc@iafrica.com; http://aidc.org.za

ALAI - Agencia Latinoamericana de Informacion

info@alainet.org; www.alainet.org

ALAMPYME - Assoc. Latino Americana de Pequenos e Médios Empresários apyme@rcc.com.ar; www.apyme.com.ar

Aliança Por Um Mundo Responsável e Solidário

lille@alliance21.org; www.alliance21.org

All Arab Peasants \& Agricultural Co-operatives Union

F76arab@maktoob.com

ALOP - Assoc. Latino Americana de Organismos de Promoção

info@alop.or.cr; www.alop.or.cr

Alternatives Information Center

yahni@alt-info.org; www.alternativenews.org

Alternatives

alternatives@alternatives.ca</a>; www.alternatives.ca

Alternative International

www.alternatives.ca

${ }^{36}$ Documento obtido no site do Fórum Social Mundial (http://www.forumsocialmundial.org.br), no link: http://www.forumsocialmundial.org.br/main.php?id menu=3_2_1\&cd_language $=1$ 
Alternatives Rússia

dhrr@online.ru

Amigos da Terra/Friends of the Earth foe@foe.org; www.foei.org

APRODEV

aprodev@aprodev.net; www.aprodev.net

Arab NGO Network for Development

annd@cyberia.net.lb; www.annd.org

ARENA - Asian Regional Exchange for New Alternatives

arena@asianexchange.org; www.asianexchange.org

Articulación Feminista Marco Sur

mujeresdelsur@mujersur.org.uy; www.mujeresdelsur.org.uy

ASC - Aliança Social Continental

sri_cut@uol.com.br; www.ascahsa.org

Asemblea de los Pueblos del Caribe (APC)

habitatcarib@hotmail.com, pedroarg@tricom.net; http://movimientos.org/caribe/

Assemblée Europeenne dês Citoyens

cedetim@globenet.org; www.cedetim.org/AEC

Assembléia das Nações Unidas dos Povos

flavio@perlapace.it

Associação para o Progresso das Comunicações

anriette@apc.org; www.apc.org

ATTAC- Brasil

attacsaopaulo@attac.org; www.attac.org/brasil

ATTAC France

attac@attac.org; http://attac.org

Babels

wsfsm@babels.org

Bankwatch Network

jozseff@bankwatch.org; www.bankwatch.org

CADTM- Comité pour l'Annulation de la Dette du Tiers Monde cadtm@skynet.be; http://users.skynet.be/cadtm 
Canadian Council

Jdunn@canadians.org

CAOI - Coordinación Andina de Organizaciones Indigenas

coordinadorandinacaoi@gmail.com; www.minkandina.org

Caritas Internacionalis

caritas.internationalis@caritas.va; www.caritas.org

CBJP - Comissão Brasileira de Justiça e Paz

intercom@cidadanet.org.br; www.cbjp.org.br

CEAAL - Cons. Educação de Adultos da Am. Latina

ceaal@laneta.apc.org; www.ceaal.org

CEDAR Internacional

cedar@asser.nl; www.cedarinternational.net

CEDETIM- Centre dEtudes et d Initiatives de Solidarité Internationale cedetim@globenet.org; www.cedetim.org

Central de Trabajadores Argentinos

cta@rcc.com.ar; www.cta.org.ar

CES - European Trade Union Confederation

etuc@etuc.org; www.etuc.org

CETRI

cetri@cetri.be; www.cetri.be

CIDSE

postmaster@cidse.org; www.cidse.org

CIOSL - Confederação Internacional de Organizações Sindicais Livres internetpo@icftu.org; www.cioslorit.org

Ciranda Internacional de Comunicação

ciranda@ciranda.net; www.ciranda.net

\section{CIVES}

cives@cives.org.br; www.cives.org.br

\section{CLACSO}

clacsofsm@clacso.edu.ar; www.clacso.org

CLC - Canadian Labour Congress

sbenedict@clc-ctc.ca; www.clc-ctc.ca

CMT - Confederação Mundial do Trabalho

info@cmt-wcl.org; www.cmt-wcl.org 
Coalición Internacional para el Hábitat

hic-al@hic-al.org; http://www.hic-net.org/

Coligação para a Justiça Econômica

viriatot@zebra.uem.mz

COMPA - Convergência de los Movimientos de los Pueblos de las Américas colectivoredom_@hotmail.com; rgf@alum.vassar.edu;

http://www.sitiocompa.org/compa/index.php

CONAIE

info@conaie.org; http://conaie.org

Congresso Nacional Indígena do México

ceatl@laneta.apc.org

Conselho Mundial de Igrejas

info@wcc-coe.org; www.wcc-coe.org

Coordenación del Foro "El Otro Davos"

Page2@fastnet.ch

Coordenadora de Centrais Sindicais do Cone Sul

eduardof@aebu.org.uy; http://www.sindicatomercosul.com.br/

Corpwatch

corpwatch@corpwatch.org; www.corpwatch.org

COSATU - Congress of South African Trade Unions

cosatu@wn.apc.org; www.cosatu.org.za

CRID - Centre de Recherche et d'Information pour le Développment

info@crid.asso.fr; www.crid.asso.fr

CSI - Confederación Sindical Internacional

claire.courteille@ituc-csi.org; http://www.ituc-csi.org

CUT - Central Única dos Trabalhadores

sri-cut@uol.com.br; www.cut.org.br

Encuentros Hemisféricos contra el ALCA

joel@mlking.sld.cu

ENDA

taoufik@enda.sn; www.enda.sn

Euralat

Criera@aepdc.org 


\section{Euromarches}

euromarches@ras.eu.org; www.euromarches.org

\section{FAMES}

rabia@enda.sn

FECOC - Frente Continental de Organizações Comunitárias mlongoria@laneta.apc.org

Federación Mundial de Juventudes Democráticas

wfdy@wfdy.org; www.wfdy.org

Féderation démocratique internationale des femmes (FDIF)

fdif@fdif.eu.org; www.fdif.eu.org

Fundación per la Pau/International Peace Bureau (IPB)

mailbox@ipb.org; www.ipb.org

FIAN - Food First International Action Network

fian@fian.org; www.fian.org

FIDH - Fed. Internacional Direitos Humanos

rsanchez@fidh.org; www.fidh.org

Focus on the Global South

admin@focusweb.org; http://focusweb.org

FORIM - Forum des Organisations de Solidarité Internationale issues des Migrations

forim@forim.net; forim@free.fr

\section{Fórum Dakar}

Residel.kaolack@sentoo.sn

Forum Mondial des Alternatives

ftm@syfed.refer.sn; www.alternatives-action.org/fma

Forum of the Poors

fopthai@asiaaccess.net.th

Fórum Social Italiano

vagnoleto@lila.it

Fundação Frantz Fanon

General Union of Oil Employees in Southern Iraq Contact: Farouk M. Sadiq Ismaa'I

101small@yahoo.com 
GLBT South-South Dialogue

dialogo@fedaeps.org

Global Commons Foundation

www.www.globalcommonsfoundation.org

Global Exchange

admin@globalexchange.org; www.globalexchange.org

Global Policy Network

gpn-listowner@epinet.org; www.globalpolicynetwork.org

Global Progressive Fórum

info@globalprogressiveforum.org; www.globalprogressiveforum.org

Grassroots Global Justice

ggj@ggjalliance.org; www.ggjalliance.org

Greenpeace

greenpeace.brazil@dialb.greenpeace.org; http://www.greenpeace.org/

Grito dos Excluídos

gritoexcluidos@uol.com.br; www.movimientos.org

Grupo de Trabalho Amazônico

www. gta.org.br

Habitat Internation Coalition

maite.martinez-pardo@delcri.cec.eu.int; www.habitat-international-coalition.org

Helsinki Citizens Assembly

Herriak Aske

international@askapena.org

IATP - Institute for Agriculture and Trade Policy

khoff@iatp.org; www.iatp.org

\section{IBASE}

ibase@ibase.br; www.ibase.br

ICAE - Conselho Internacional de Educação de Adultos

icae@icae.ca; http://www.icae.org.uy/spa/sindex.html

IFAT - International Federationof Alternative Trade

info@ifat.org.uk; www.ifat.org

IFG - International Forum on Globalization

ifg@ifg.org; www.ifg.org 
International Alliance of Habitants

info@habitants.org; www.habitants.org

International drama and education association (IDEA)

www.idea-org.net

International Gender and Trade Network

secretariat@igtn.org; www.igtn.org

International Network of Street Papers (INSP)

I.maclean@bigissuescotland.com; irn@irn.org; www.irn.org

Instituto Paulo Freire

ipf@paulofreire.org; www.paulofreire.org

IPAO - Institut Panos Afrique de l'Ouest

info@panos-ao.org; www.panos-ao.org

IPS - Inter Press Service

kosi@ips.org; www.ips.org

Ittijah - Union of Arab Community Based Organisations

ittijah@ittijah.org; www.ittijah.org

Jubilee South - Asia

vinod.raina@vsnl.com; www.jubileesouth.org

Jubileo South - África

aidc@iafrica.com; www.jubileesouth.org

Jubileu 2000

kitazawa@jca.apc.org

Jubileu Sul América Latina

keeneba@wamani.apc.org; www.jubileusul.hpg.com.br

KCTU - Korean Confederation of Trade Unions

inter@kctu.org; www.kctu.org

Kenya Debt Network

sodnet@sodnet.or.ke

\section{KOPA}

kopa@jinbo.net; http://antiwto.jinbo.net/eroom/index.html

Kurdish Network

kurdishnetwork@orange.fr 
MST - Movimento dos Trabalhadores Sem Terra

srimst@uol.com.br; www.mst.org.br

Narmada

subbu@narmada.org; www.narmada.org

National Network of Autonomous Women's Groups

shahnandita@redifmail.com

NIGD - Network Institute for Global Democratization

katarina@nigd.u-net.com; www.nigd.org

North-South Centre

Fifi.BENABOUD@coe.int; www.coe.int/T/E/North-South_Centre

OCLAE - Continental Organization of Latin America and Caribbean Students oclae@jcce.org.cu; www.oclae.org

Organization of African Trade Unions Unity

oatuu@ighmail.com

ORIT - Org. Regional Interamericana de Trabalhadores

info@cioslorit.org; www.orit-ciosl.org

Organization de la Jeunesse Africaine

http://www.ojafrique.org/

OXFAM Internacional

information@oxfaminternational.org; www.oxfam.org

Palestinian grassroots Anti-Apartheid Wall Campaign

mobilize@stopthewall.org; www.stopthewall.org

Peace Boat

y-nami@peaceboat.gr.jp; www.peaceboat.org

Peoples Health Movement

secretariat@phmovement.org; http://www.phmovement.org

Plataforma Interamericana de Derechos Humanos, Democracia y Desarrollo regional@pidhdd.org; www.pidhdd.org

PPEHRC - Poor People's Economic Human Rights Campaign

kwru@kwru.org; www.economichumanrights.org; www.kwru.org

Projeto K

Salvatore.cannavo@flashnet.it

ilpanelerose@hotmail.com 
Public Citizen

tgerson@citizen.org; www.citizen.org

Red Latinoamericana Mulheres Transformando a Economia

mleon@interactive.net.ec; remte@fedaeps.org; http://movimientos.org/remte

Rede APM - Agricultures paysannes, sociétés et mondialisation pvuarin@fph.fr; www.zooide.com/apm

Rede CONSEU (Conferencia de Naciones sin Estado de Europa)

activitats@ciemen.org

Rede Dawn de Mulheres

dawn@is.com.fj; www.dawn.org.fj

Rede de Solidariedade Ásia Pacífico

intl@dsp.org.au

Rede Latino-Americana e Caribenha de Mulheres Negras

criola@alternex.com.br; www.criola.ong.org

Rede Mulher e Habitat

gem@agora.com.ar; http://www.redmujer.org.ar

Rede Mundial de Mulheres pelos Direitos Reprodutivos

office@wgnrr.nl; www.wgnrr.org

Rede Palestina de ONGs

bisanrd@palnet.com; www.pngo.net

Rede Social de Justiça e Direitos Humanos

rede@social.org.br; www.social.org.br

Rede Transforme!

elgauthi@internatif.org

Redes Socioeconomia Solidaria

creintjes@ideas.coop; www.reasnet.com

REPEM - Rede de Educação Popular entre Mulheres

repem@repem.org.uy; www.repem.org.uy

Réseaux Sous -régional sur la Dette et les DSRP jubilecad-mali@cefib.com, barryaminatou@yahoo.fr

SIGTUR - Southern Initiative on Globalisation and Trade Union Rights rlambert@ecel.uwa.edu.au 
Social Movement Indaba

Social Watch

socwatch@chasque.net; www.socialwatch.org

SODNET - Social Development Network

sodnet@sodnet.or.ke; http://www.sodnet.or.ke

Solidar

solidar@skynet.be; www.solidar.org

Solidarity Africa Network in Action

njoki@igc.org

The International Federation Terre des Hommes (IFTDH)

info@terredeshommes.org; www.terredeshommes.org

TIE - Transnational Information Exchange

tie@tie-brasil.org; http://www.tie-brasil.org/tie.php

TNI - Transnational Institute

tni@tni.org; www.tni.org

TWN - Third World Network

twn@igc.apc.org; www.twnside.org.sg

UBUNTU - Foro Mundial de Redes de la Sociedad Civil

ubuntu@ubuntu.upc.es; www.ubuntu.upc.es

Union Internacional de Estudiantes

ius@cfs-fcee.ca; www.ius-uie.org

Vasudhaiva Kutumbakam Network

vk-finland@kaapeli.fi; www.democracydialogues.org/

www.demokratiafoorumi.fi/wsf.html

Via Campesina

viacam@gbm.hn; http://ns.rds.org.hn/via/

World Association of Community Radio Broadcasters (Amarc)

amarc@amarc.org; http://www.amarc.org

World March of Women

www.ffq.qc.ca/marche2000/en/index.html; dmatte@ffq.qc.ca

Zanzibar International Film Festival Of Dhow

Contato: Fatma ALLOO

falloo@zitec.org

Znet 
sysop@zmag.org; www.zmag.org

\section{OBSERVADORES}

Comitê Organizador do Fórum Mundial de Educação

Comitê Organizador do Fórum Social Africano taoufik@enda.sn

Comitê Organizador do Fórum Social Américas

fsmcontinental@fsmecuador.org; www.forosocialamericas.org

Comitê Organizador do Fórum Social Europeu

wsf@fse-esf.org; www.fse-esf.org

Comitê Organizador do Fórum Social Mediterrâneo activitats@ciemen.org; fsmedi@terra.es

Comitê Organizador do Fórum Social de Migrações

Comitê Organizador do Fórum Social Pan-Amazônico cri-pmb@belem.pa.gov.br; www.fspanamazonico.com.br

Comitê Organizador do Fórum Social Tematico: Democracia, Direitos Humanos, Guerras e Narcotráfico forosocialtematico@cable.net.co; www.fsmt.org.co

FNTG - Funders Network on Trade \& Globalization mark@fntg.org; www.fntg.org

Fórum São Paulo 


\section{ANEXO C - Notícias}

\section{Um país cada vez mais digital ${ }^{37}$}

\section{$30 / 7 / 2008$}

Agência FAPESP - O número de brasileiros que acessam a internet cresceu seis pontos percentuais em relação a 2006, chegando a 34\% em 2007. Dos domicílios no país, $24 \%$ já contam com computador.

Os dados são da Pesquisa sobre o Uso das Tecnologias da Informação e da Comunicação no Brasil 2007, publicada pelo Centro de Estudos sobre as Tecnologias da Informação e da Comunicação (Cetic.br) do Comitê Gestor da Internet no Brasil (CGI.br).

Iniciada em 2005, a nova edição da pesquisa apontou pela primeira vez que mais da metade $(53 \%)$ da população consultada disse ter usado computador, dos quais $40 \%$ nos últimos três meses. Foram feitas entrevistas em 17 mil domicílios em zonas urbanas, com pessoas a partir de 10 anos de idade.

O crescimento mais expressivo da aquisição de computadores ocorreu em domicílios com renda entre três e cinco salários mínimos, nos quais a penetração passou de $23 \%$ para $40 \%$ no período. A proporção de domicílios com computador aumentou em todas as regiões do país.

Mais da metade dos domicílios com acesso à internet têm banda larga, um aumento de 10 pontos percentuais em relação ao ano anterior. Mas $42 \%$ ainda têm acesso discado. Das casas com acesso rápido, em $12 \%$ a conexão é usada por mais de um computador.

A pesquisa também ressalta o expressivo crescimento no uso de centros de acesso pago, como as lan houses ou internet cafés, que pulou de 30\% em 2006 para $49 \%$ no ano seguinte. Quanto menor a renda da população, maior é a utilização desses espaços. Dos usuários de internet com renda de até um salário mínimo, $78 \%$ disseram utilizar a rede por meio desses centros de acesso pago. $\mathrm{O}$ acesso no trabalho foi apontado por $24 \%$ dos entrevistados.

"Se por um lado, a ausência do computador em casa não impede o uso das tecnologias da informação, também é evidente que a disponibilidade do computador no domicílio pode influenciar a freqüência e a intensidade de seu uso", apontou Rogério Santanna dos Santos, secretário de Logística e Tecnologia da Informação do Ministério do Planejamento e conselheiro do CGI.br, em artigo no relatório.

O secretário destacou o programa Banda Larga nas Escolas, lançado em abril e que pretende oferecer, até o fim de 2010, acesso rápido à internet a todos os alunos das

\footnotetext{
${ }^{37}$ A notícia pode ser encontrada através do link: http://www.agencia.fapesp.br/materia/9201/noticias/um-pais-cada-vez-mais-digital.htm
} 
escolas públicas do ensino fundamental e médio situadas na área urbana das cinco regiões do Brasil.

A publicação do Cetic.br destaca também o elevado uso das tecnologias de informação pelo setor privado brasileiro, especialmente entre empresas de grande porte, das quais $95 \%$ têm computadores e $92 \%$ têm acesso à internet. Destaque para o crescimento das redes sem fio nas empresas, que passou de $18 \%$ em 2006 para $28 \%$ no ano seguinte. O número de companhias que usou a internet para aquisição de bens e serviços chegou a $64 \%$.

Dos entrevistados, $66 \%$ disseram ter usado telefone celular nos três meses anteriores. $O$ uso foi alto em todas as faixas de renda, com $48 \%$ entre os que ganham menos de $\mathrm{R} \$ 380$ por mês e $84 \%$ entre os acima de $\mathrm{R} \$ 3,8$ mil.

A Pesquisa sobre o Uso das Tecnologias da Informação e da Comunicação no Brasil 2007 pode ser baixada em formato pdf no endereço www.cetic.br/tic/2007/indicadores-cgibr-2007.pdf. 


\title{
A explosão da Internet na China é um desafio para as autoridades ${ }^{38}$
}

\author{
$30 / 07 / 2008$ \\ 8 \\ Brice Pedroletti \\ Em Xangai, China
}

Com 253 milhões de chineses conectados, segundo as mais recentes estatísticas do China Internet Network Information Centre (CNNIC), a China torna-se o país com o maior número de usuários da Internet, e desbanca os Estados Unidos, que contam cerca de 230 milhões de internautas. O número de chineses que se conectam na Web $(80 \%$ dos quais têm acesso à Internet banda larga) deu um salto de $56,2 \%$ desde junho de 2007. Além disso, este número deve continuar crescendo, pois o país ainda apresenta um grande potencial reprimido, uma vez que a sua taxa de penetração da Internet, que é de 19,1\%, permanece num nível modesto - esta é de $21,1 \%$ em média no mundo inteiro, ultrapassando $71 \%$ na Coréia do Sul e nos Estados Unidos, ao passo que ela é de 5,3\% apenas na Índia.

Os interesses em jogo são consideráveis, tanto em termos econômicos quanto políticos. Isso porque a China conta atualmente 84,7 milhões de computadores pessoais conectados à rede nos lares chineses. Os três quartos dos internautas se conectam a partir da sua casa, e $39,2 \%$ a partir dos wang baa (cibercafés), abertos 24 horas por dia. Cerca de 107 milhões de chineses dizem manter um blog ou algum espaço pessoal on-line. A música on-line aparece em primeiro lugar entre as suas ocupações prediletas ( $84,5 \%$ das pessoas entrevistadas). Seguem-se entre os favoritos os sites de notícias $(81,5 \%)$, os sites de comunicação instantânea $(77,2 \%)$ e os de vídeos on-line $(71,0 \%)$.

Esta expansão acelerada dos canais de expressão e de informação transformou por completo a configuração do jogo político na China: dentro de um contexto no qual os veículos de comunicação continuam sendo submetidos à censura das autoridades $\mathrm{e}$ onde as pesquisas independentes foram banidas, a Internet desponta como 0 barômetro de uma opinião pública não raro recalcada, "mantida em estado bruto", e que nunca é levada em consideração. A extrema capacidade de reação dos internautas constitui um catalisador de mudanças para a imprensa, que não pode ignorar os debates on-line.

"As reportagens realizadas por um cidadão blogueiro tal como Zola [o codinome utilizado por um deles] fizeram com que as autoridades compreendessem que era ilusório querer impor um 'blecaute' da informação na era dos blogs. Com isso, o regime vem se tornando mais sutil em sua abordagem. Ele autorizou uma maior cobertura dos veículos tradicionais por ocasião de eventos tais como os motins de Weng'na, no Guizhou, em junho, o que enfraqueceu a influência dos blogs", analisa Rebecca Mac Kinnon, que ensina os novos meios de comunicação no centro de jornalismo da universidade de Hong-Kong.

Para manterem o controle da situação diante da formidável expansão da Internet no país, as autoridades de Pequim lançaram mão de um arsenal legislativo, tecnológico

${ }_{38}$ A notícia foi publicada no site UOL (www.uol.com.br) e pode ser encontrada através do link: http://noticias.uol.com.br/midiaglobal/lemonde/2008/07/30/ult580u3221.jhtm 
e humano: é o caso da ciberpolícia, ou ainda dos "comentaristas da Internet" que atuam a serviço do Partido Comunista chinês. Com isso, a "grande muralha virtual" segue bloqueando o acesso aos sites locais ou estrangeiros considerados como "sensíveis".

A atribuição, por parte das autoridades, de licenças aos grandes atores da Internet (portais, sites de vídeos on-line, comunidades) permite obter a submissão destes últimos. Foi assim que, no final de junho, a administração de tutela do audiovisual chinês concedeu licenças para 247 sites de vídeos chineses, mas não renovou as dos três mais importantes (Youku, Tudou e 56), nos quais os internautas haviam adquirido a mania, aos seus olhos um pouco excessiva, de publicar on-line vídeos, em muitos casos filmados por meio de telefones celulares, de incidentes embaraçosos.

Um desses sites, o 56.com, permaneceu inacessível durante mais de duas semanas até ser novamente disponibilizado, uma censura que causou uma intensa preocupação aos fundos americanos e japoneses que nele haviam investido milhões de dólares. Desde então, os três "Youtube" chineses vêm mostrando que eles entenderam a lição.

Tradução: Jean-Yves de Neufville 


\section{O caso Pirate Bay e a indústria do copyright ${ }^{39}$}

\section{$23 / 04 / 2009$}

Em 17 de Abril de 2009 quatro pessoas foram consideradas culpadas pela corte sueca pelo crime de promover a quebra da lei de direitos autorais por manterem um site de compartilhamento de conteúdos na internet. O site Pirate Bay desde 2003 funciona como um tracker BitTorrent, operacionalizando uma rede de trocas online baseada na cultura de distribuição aberta e livre de manifestações culturais das mais diversas, entre filmes, música, jogos e outros.

Fredrik Neij, Gottfrid Svartholm Warg, Peter Sunde e Carl Lundström foram sentenciados a um ano de prisão e ao pagamento de cerca de 2.7 milhões de euros como indenização pela perda de royalties à indústrias fonográficas e de entretenimento, entre elas, Warner, Sony, EMI, Columbia Pictures e Universal Music. Outro caso recente é o do professor de filosofia Horacio Potel, que está enfrentando um processo judicial na Argentina por manter um site educacional dedicado a traduções para o espanhol dos escritos do filósofo francês Jacques Derrida.

Apoiadas numa crítica da 'cultura da licença' e fundamentadas na idéia de que a internet precisa estar livre de mediações com qualquer indústria que restrinja o direito de cópia e compartilhamento de bens culturais, milhares de pessoas se manifestaram durante a semana em diversas cidades do mundo rejeitando a decisão judicial sueca. A criminalização de práticas que promovem a fluidez do conhecimento, da tecnologia e da criatividade representa uma das facetas da frente reacionária que pretende acirrar o controle dos usos da internet no mundo (haja visto o projeto de lei brasileira do senador Eduardo Azeredo). O modelo global de licenças de proteção à propriedade intelectual que está sendo imposto à internet, usuários/as e desenvolvedores/as, não 'garante o sustento' de artistas e produtores/as culturais. Ao contrário, tem sido elaborado e implementado para garantir que meia dúzia de corporações mantenham o monopólio de comercialização e exploração de um bem público e livre.

O site Pirate Bay ainda está em funcionamento. Nesta quinta-feira (23/04/2009) a defesa do site solicitou a repeticão do julgamento por causa das notícias que sairam sugerindo parcialidade por parte do juíz Tomas Norström. O juíz e os advogados que representam os donos dos copyrights no caso Pirate Bay são membros da Associação Sueca pelos Direitos Autoriais (SFU). Além disso o juíz é membro da diretoria da Associação Sueca pela Proteção Legal Industrial (SFIR) - que lida com questões de patente e direitos de design industrial - e também é membro conselheiro do 'Tingsretten' (Corte da Propriedade).

\footnotetext{
${ }^{39}$ A notícia pode ser encontrada no site: http://www.midiaindependente.org/
} 


\section{ATO CONTRA O AI-5 DIGITAL ${ }^{40}$}

\section{$30 / 04 / 2009$}

A Internet é uma rede de comunicação aberta e livre. Nela, podemos criar conteúdos, formatos e tecnologias sem a necessidade de autorização de nenhum governo ou corporação. A Internet democratizou o acesso a informação e tem assegurado práticas colaborativas extremamente importantes para a diversidade cultural. A Internet é a maior expressão da era da informação.

A Internet reduziu as barreiras de entrada para se comunicar, para se disseminar mensagens. E isto incomoda grandes grupos econômicos e de intermediários da cultura. Por isso, se juntam para retirar da Internet as possibilidades de livre criação e de compartilhamento de bens culturais de de conhecimento.

Um projeto de lei do governo conservador de Sarkozi tentou bloquear as redes P2P na França e tornar suspeitos/as de prática criminosa todos/as os/as seus/as usuários/as. O projeto foi derrotado.

No Brasil, um projeto substitutivo sobre crimes na Internet aprovado e defendido pelo Senador Azeredo está para ser votado na Câmara de Deputados. Seu objetivo é criminalizar práticas cotidianas na Internet, tornar suspeitas as redes P2P, impedir a existência de redes abertas, reforçar o DRM que impedirá o livre uso de aparelhos digitais. Entre outros absurdos, o projeto quer transformar os provedores de acesso em uma espécie de polícia privada. O projeto coloca em risco a privacidade dos/as internautas e, se aprovado, elevará o já elavado custo de comunicação no Brasil.

Gostaríamos de convidá-lo/a a participar do ato público que será realizado no dia 14 de maio, às $19 \mathrm{~h} 30$, em defesa da:

\section{- LIBERDADE NA INTERNET}

- CONTRA O VIGILANTISMO NA COMUNICAÇÃO EM REDE

- CONTRA O PROJETO DE LEI SUBSTITUTIVO DO SENADOR AZEREDO

O Ato será na Assembléia Legislativa de São Paulo e será transmitido em streaming para todo o país pela web.

\section{PLENÁRIO FRANCO MONTORO}

\section{ASSEMBLÉIA LEGISLATIVA DE SÃO PAULO AV PEDRO ALVARES CABRAL S/N - IBIRAPUERA}

O ato também terá cobertura em tempo real pelo Twitter e pelo Facebook.

Contamos com a sua presença.

Comitê Organizador

\footnotetext{
${ }^{40}$ A notícia pode ser encontrada no site: http://www.midiaindependente.org/
} 


\section{França aprova lei e vai suspender internauta que fizer download ilegal ${ }^{41}$}

\section{$13 / 05 / 2009$}

da France Presse, em Paris

A França aprovou nesta quarta-feira (13), em definitivo, o projeto de lei sobre a internet que estabelece a suspensão do acesso à rede para as pessoas que fizerem downloads ilegais, o que torna o país um dos mais rígidos neste aspecto. A proposta foi aprovada pelo Senado.

Depois da aprovação pelos deputados nesta terça-feira (12), o texto foi ratificado por ampla maioria (189 votos a favor, 14 contra) pela bancada conservadora (UMP, partido do presidente Nicolas Sarkozy) e os aliados centristas. A oposição socialista e comunista, que categorizou a legislação como "um assalto público das liberdades individuais", não participou na sessão.

A França se torna assim o primeiro país europeu a aplicar uma lei com a suspensão do acesso a internet. O novo texto indica a suspensão do acesso à internet para os reincidentes de downloads ilegais por um período de até um ano. O texto prevê que o usuário seja obrigado a pagar a conexão durante o período de sanção, após duas advertências por carta.

A proibição do acesso à internet substitui as atuais legislações, que preveem três anos de prisão e 300 mil euros em multas.

Mais de 10 mil artistas franceses, cineastas, músicos e personalidades da cultura assinaram uma petição em suporte à lei. A ministra da Cultura da França, Christine Albanel, admitiu que a lei tem uma pequena chance de erradicar "o fenômeno mundial que é a pirataria de produtos culturais".

Na semana passada, o Parlamento Europeu desconsiderou a legislação para internautas que fazem downloads ilegais de arquivos de músicas e filmes pela internet -- em uma decisão que assinalou a preocupação quanto ao estrangulamento dos direitos de consumidores inocentes.

O projeto de lei, introduzido na Casa europeia pela França e outros países, previa a interrupção do acesso à internet de supostos casos de pirataria relativos à troca de arquivos de entretenimento.

\footnotetext{
${ }^{41}$ A notícia foi publicada no Caderno Informática na Folha Online (www.folha.uol.com.br/) e pode ser encontrada através do link: http://www1.folha.uol.com.br/folha/informatica/ult124u565121.shtml
} 


\title{
Ódio se torna viral em sites de redes sociais-relatório ${ }^{42}$
}

\author{
$13 / 05 / 2009$
}

\section{Por Claudia Parsons}

NOVA YORK (Reuters) - Militantes e grupos de promoção do ódio cada vez mais usam sites de redes sociais como o Facebook, MySpace e YouTube na função de ferramentas de propaganda para recrutar novos membros, de acordo com um relatório do Simon Wiesenthal Center.

O relatório divulgado nesta quarta-feira notou um aumento de 25 por cento no ano passado no número de grupos "problemáticos" nas redes sociais da Web.

O estudo se baseia em "mais de 10 mil sites, grupos de redes sociais, portais, blogs, salas de chat, vídeos e jogos na Internet que promovem a violência racial, o antissemitismo, a homofobia, a música de ódio e o terrorismo".

"Cada aspecto da Internet está sendo usado por extremistas de todos os matizes para reaproveitar velhos ódios, vilipendiar o 'Inimigo', arrecadar fundos e, desde o 11 de setembro, recrutar e treinar terroristas para a Jihad", afirmou o Simon Wiesenthal Center em comunicado.

O grupo judaico de defesa dos direitos humanos que porta o nome de um renomado perseguidor de nazistas vem monitorando a Internet em busca de extremistas há uma década, e afirma que a ascensão de sites de redes sociais como o Facebook acelerou a difusão de opiniões racistas e fanáticas nos últimos anos.

A organização afirma que dirigentes do Facebook se reuniram com seus especialistas e prometeram remover da rede os sites que violem os termos de uso da organização, mas que "com mais de 200 milhões de usuários, os fanáticos online conseguem escapar mais rápido do que os esforços para removê-los são realizados", diz o documento.

O grupo apontou para o fato de que o Facebook recentemente removeu diversos sites que negam o Holocausto e divulgou um comunicado no qual esta aponta que sua rede também é amplamente utilizada para promover causas positivas.

"Nos casos em que conteúdo que promove o ódio é exibido no site, o Facebook o remove e bloqueia as contas responsáveis", afirma o comunicado da empresa.

Grupos extremistas também estão estabelecendo sites próprios de redes sociais, segundo o relatório, apontando para o exemplo do "New Saxon", descrito como "um site de redes sociais para pessoas de ascendência europeia", produzido por um grupo neonazista dos Estados Unidos chamado National Socialist Movement.

\footnotetext{
${ }^{42}$ A notícia foi publicada no Yahoo NOTÍCIAS (http://br.yahoo.com/) e pode ser encontrada através do link: http://br.tecnologia.yahoo.com/article/13052009/5/noticias-tecnologia-odio-se-torna-viral.html
} 
Outros grupos criaram jogos online como o "Special Operation 85 - Hostage Rescue", desenvolvido por uma organização iraniana, no qual o jogador precisa localizar cientistas nucleares tomados como reféns por norte-americanos no Iraque e detidos em uma prisão de Israel.

Os grupos mais visados na Internet, segundo o relatório, incluem judeus, católicos, muçulmanos, hindus, gays, mulheres e imigrantes. 


\section{Caça aos piratas}

Tribunais e leis apertam o cerco contra sites de downloads ilegais; o popular Mininova vai a julgamento hoje ${ }^{43}$

\section{$02 / 06 / 2009$}

\section{BRUNA BITTENCOURT DA REPORTAGEM LOCAL}

A batalha travada entre sites de downloads (de filmes, séries e música) e a indústria de entretenimento, que defende a proteção de direitos autorais, passa atualmente pelo seu momento mais acirrado, mas está ainda longe de uma solução.

$\mathrm{Na}$ tarde de hoje, o site Mininova (www.mininova.org), um dos mais populares para downloads, vai a tribunal, na Holanda. O Mininova é acusado de distribuição de material protegido por direito autoral por uma associação holandesa antipirataria, chamada Brein.

O objetivo da associação, que representa de artistas a produtores de música, é fazer com que o site holandês passe a filtrar seus resultados de busca e bloqueie arquivos que tenham direitos autorais protegidos.

O julgamento do Mininova acontece menos de dois meses após o site Pirate Bay (www.piratebay.org) ter ido ao tribunal. No dia 17 de abril, quatro diretores do site de troca de arquivos da Suécia foram condenados pela Justiça do país a um ano de prisão, além do pagamento de US\$3,6 milhões (cerca de $\mathrm{R} \$ 7,2$ milhões) a empresas da indústria de entretenimento por cumplicidade na violação dos direitos autorais.

O cantor e compositor Paul McCartney chegou a apoiar publicamente o veredicto, sintetizando a insatisfação de muitos artistas: "Se você pega um ônibus, deve pagar pelo bilhete", disse o músico.

O caso, no entanto, está longe do fim. Os diretores do Pirate Bay avisaram que apelariam da decisão. Quase dez dias depois, solicitaram um novo julgamento, por meio de seus advogados, alegando que o juiz responsável pelo veredicto fez parte de grupos suecos de defesa de direito autoral e, portanto, foi parcial em sua decisão. A juíza convocada a analisar o caso foi afastada pelo mesmo motivo, segundo jornais suecos. Enquanto o caso segue em aberto, o site permanece no ar. Fora dos tribunais, o Senado francês aprovou, no último dia 13, uma lei que irá punir com desconexão da internet usuários que fizerem downloads ilegais. A nova lei obriga provedores de internet a fornecer a identidade de quem baixar material protegido por direito autoral. Os internautas que o fizerem serão advertidos por email. Se insistirem, serão mais uma vez repreendidos por carta e, depois, banidos da internet por um ano e terão que continuar a pagar pelo serviço.

O editor da revista de tecnologia norte-americana "Wired", Chris Anderson, coloca em dúvida a eficácia da lei, mas acredita tratar-se de um aviso repreensivo. "Eles estão mandando um recado", diz.

Segundo o advogado Renato Opice Blum, especializado em direito autoral e eletrônico, os dois julgamentos, assim como a nova lei francesa, terão pouco impacto na vida do internauta brasileiro, por não estarem relacionados diretamente a cidadãos ou à legislação do Brasil, que também prevê este tipo de processo. "Mas

\footnotetext{
${ }^{43}$ A notícia foi publicada no Caderno llustrada na Folha Online (www.folha.uol.com.br/) e pode ser
} encontrada através do link: http://www1.folha.uol.com.br/folha/ilustrada/ult90u575135.shtml 
teremos um impacto cultural, do que se pode ou não fazer. Tudo isso mostra que a internet não é um mundo sem leis e que existem processos", diz. 


\section{ANEXO D - Fotos ilustrativas}

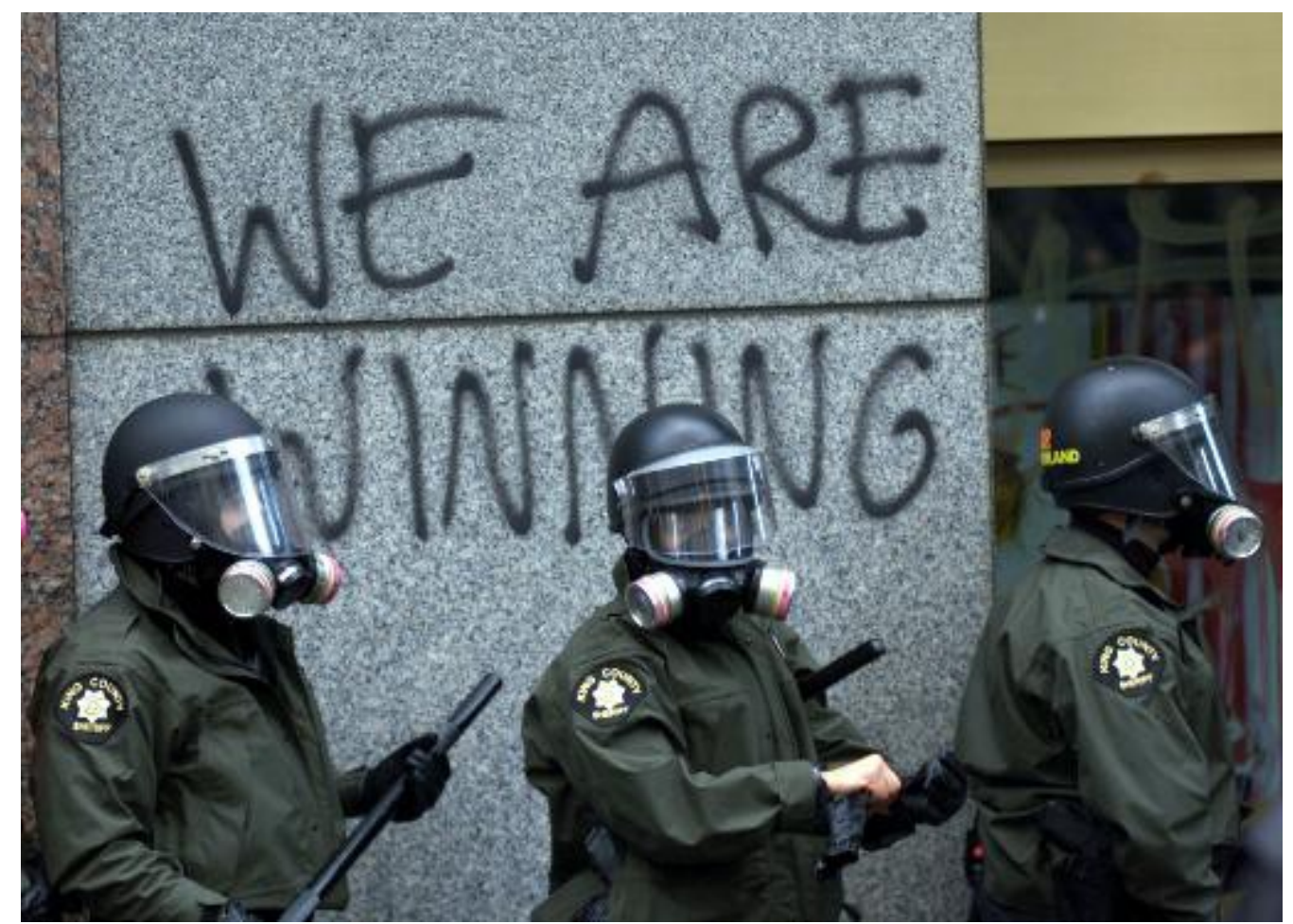

Seattle, EUA, 1999. Muro com os dizeres: "We are winning" ("Estamos vencendo")

Fonte: http://www.nadir.org/nadir/initiativ/agp/images/global/2-seattle/0630wtowinning.jpg

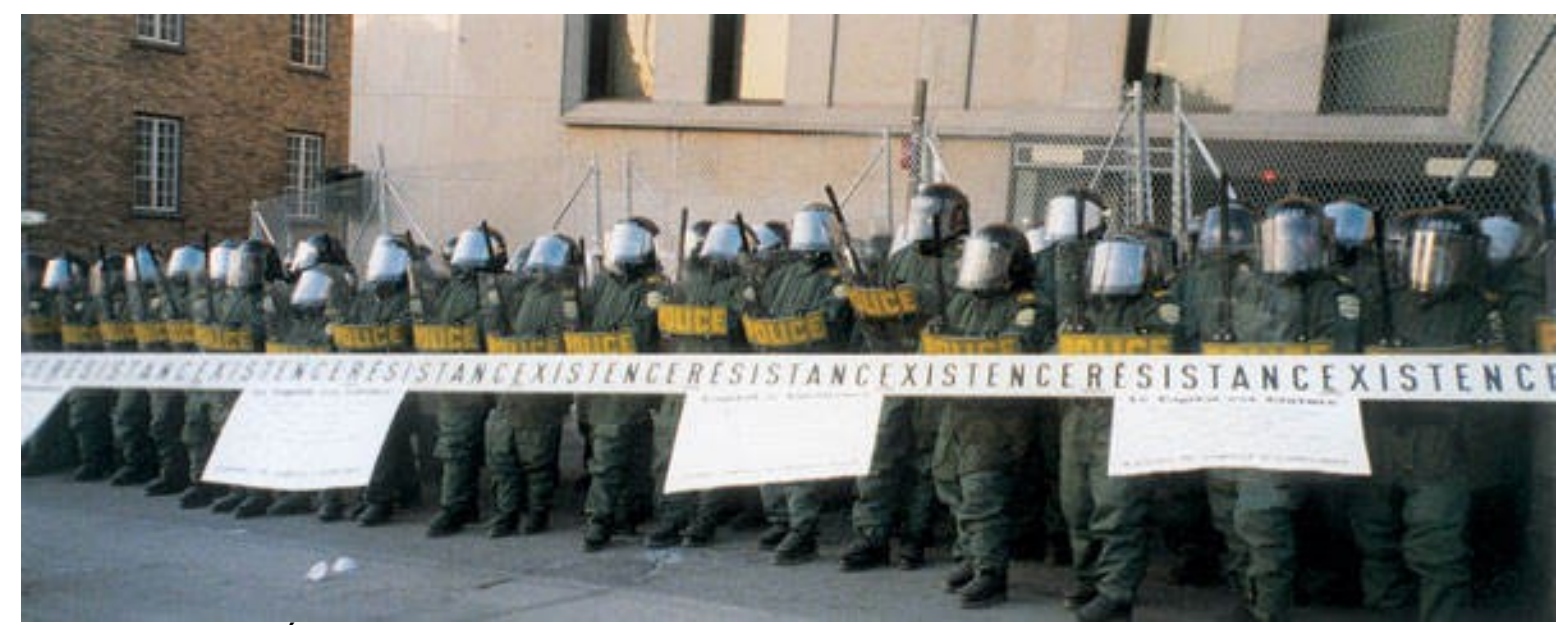

Protestos contra Área de Livre Comércio das Américas em Quebeque, Canadá, 2001. Faixa com os dizeres: "Existence-Resistance" ("Existência-Resistência")

Foto: John Jordan

Fonte: http://weareeverywhere.org/ 


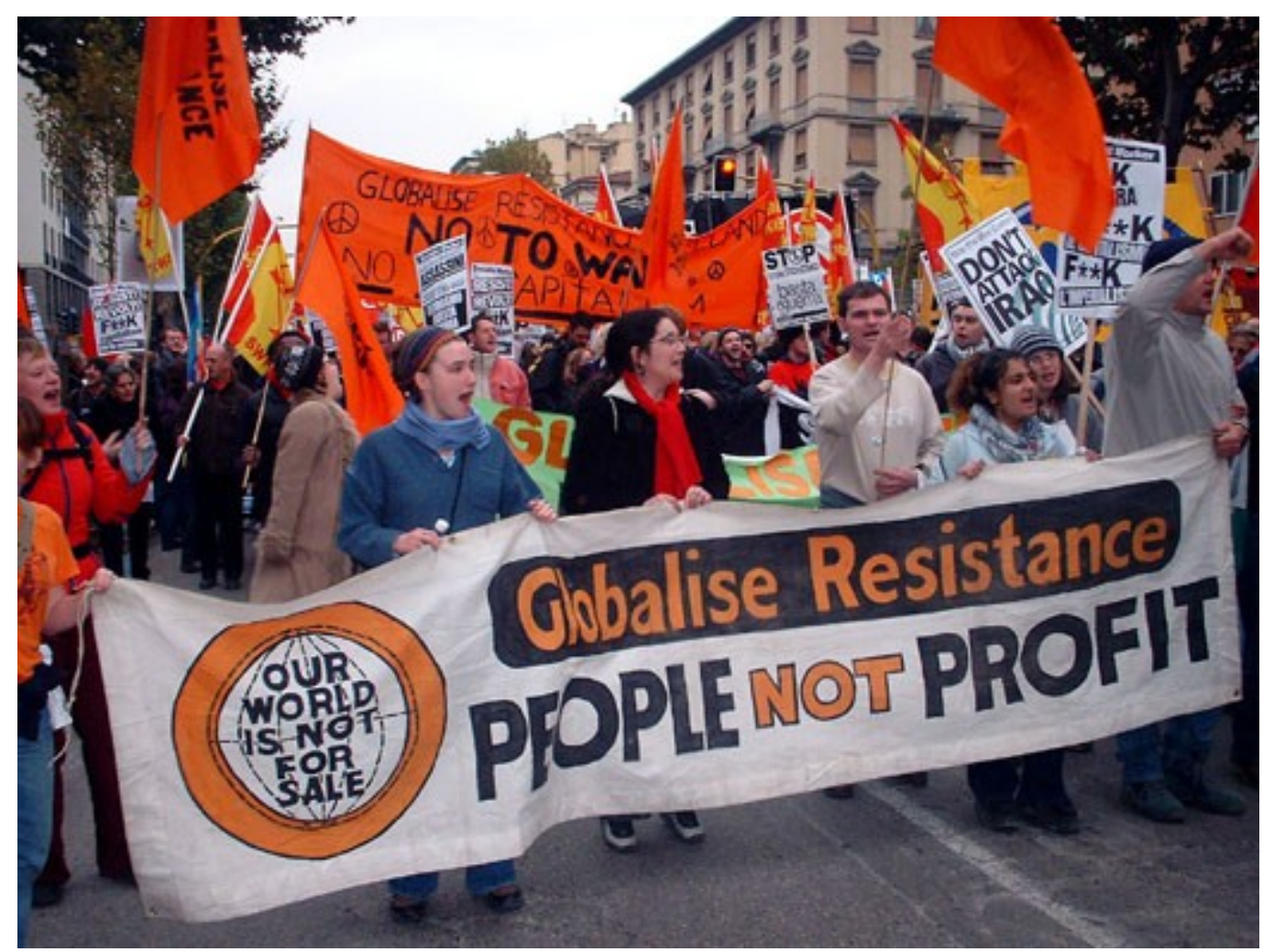

I Fórum Social Europeu (2002) - Florença, Itália

Fonte: http://www.resist.org.uk 


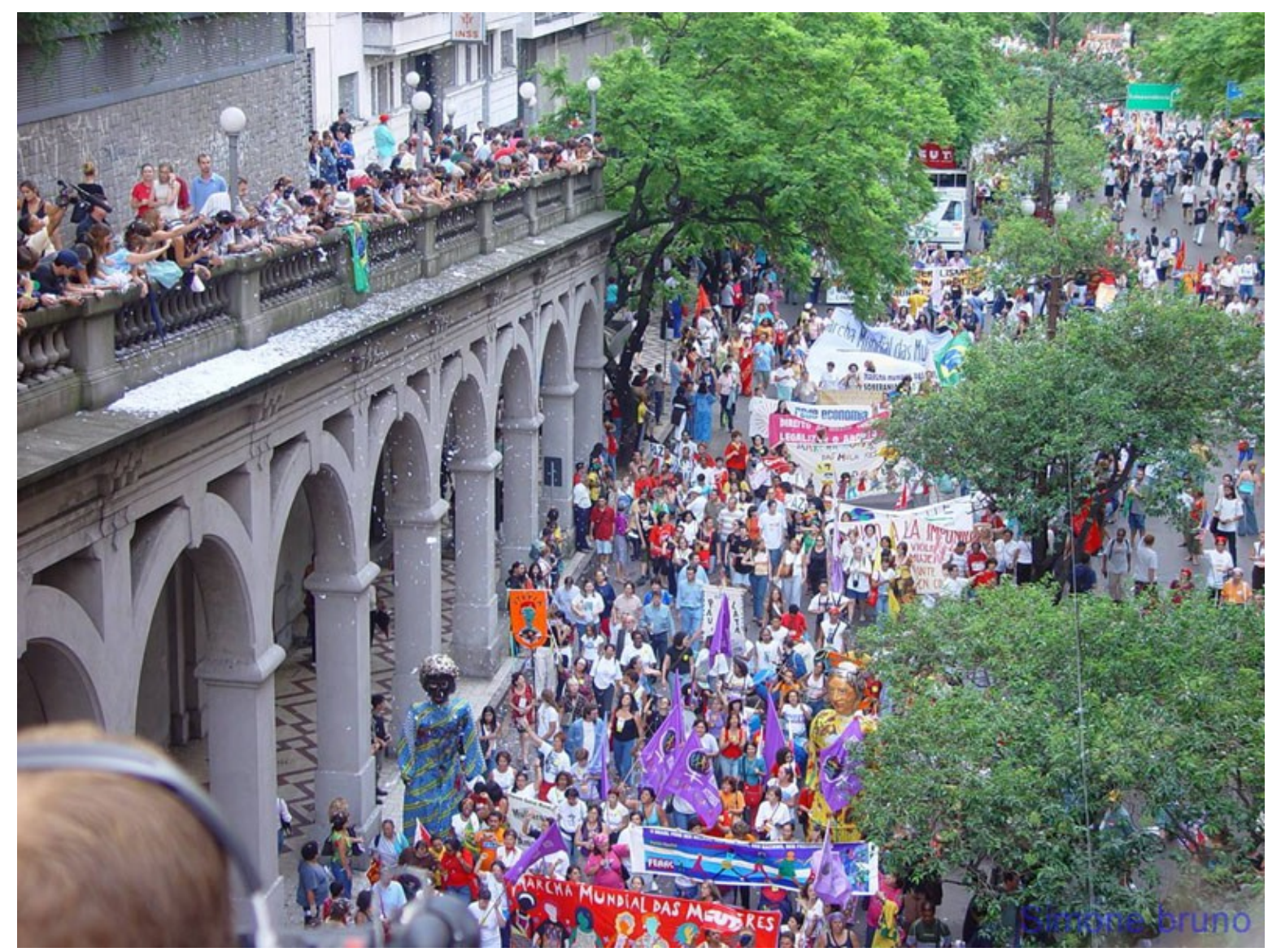

Marcha de abertura do Fórum Social Mundial 2003 - Porto Alegre, Brasil

Foto: Simone Bruno

Fonte: http://www.simone.bruno.name/ 


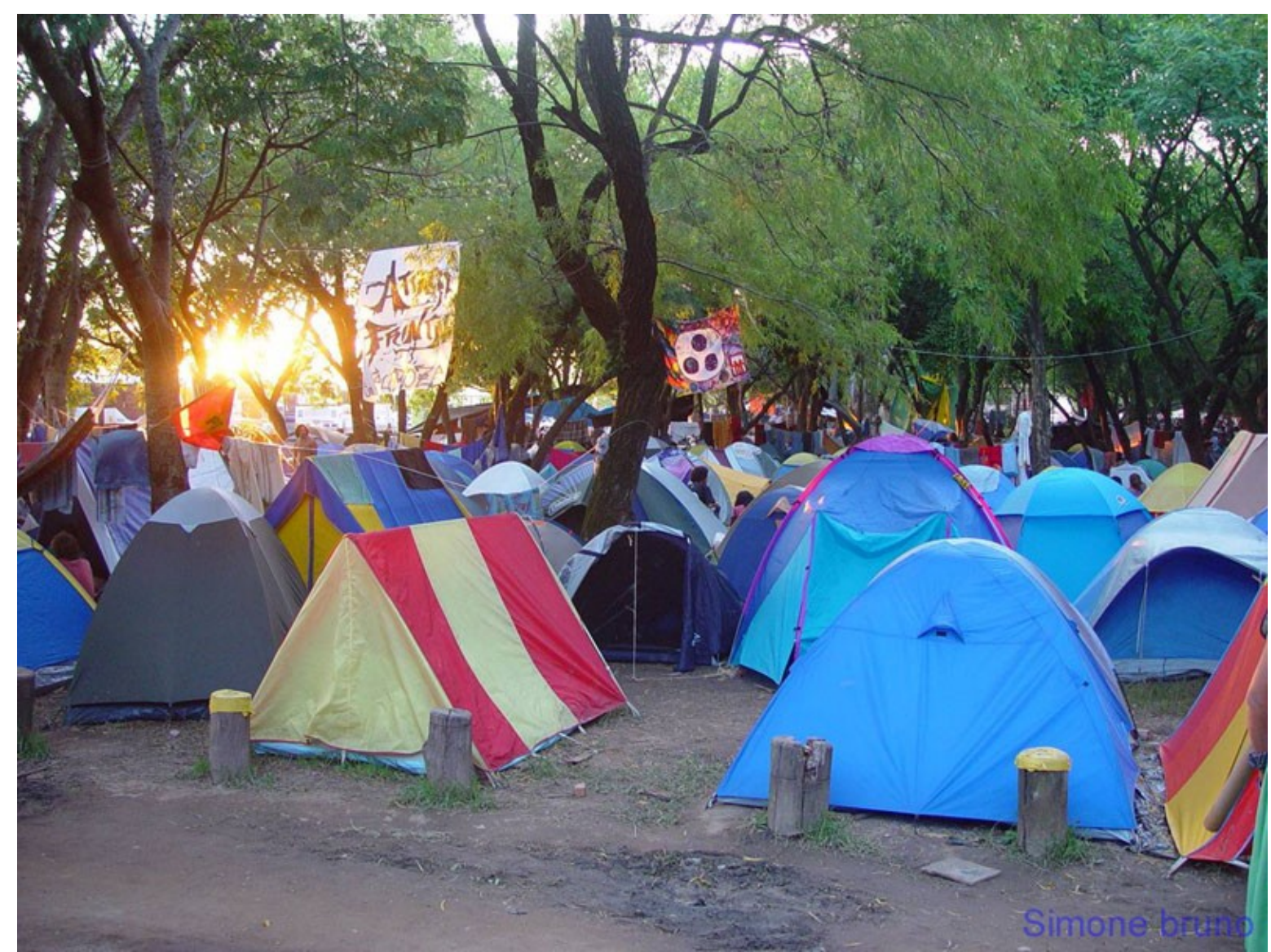

Acampamento da Juventude do Fórum Social Mundial 2003 - Porto Alegre, Brasil

Foto: Simone Bruno

Fonte: http://www.simone.bruno.name/ 


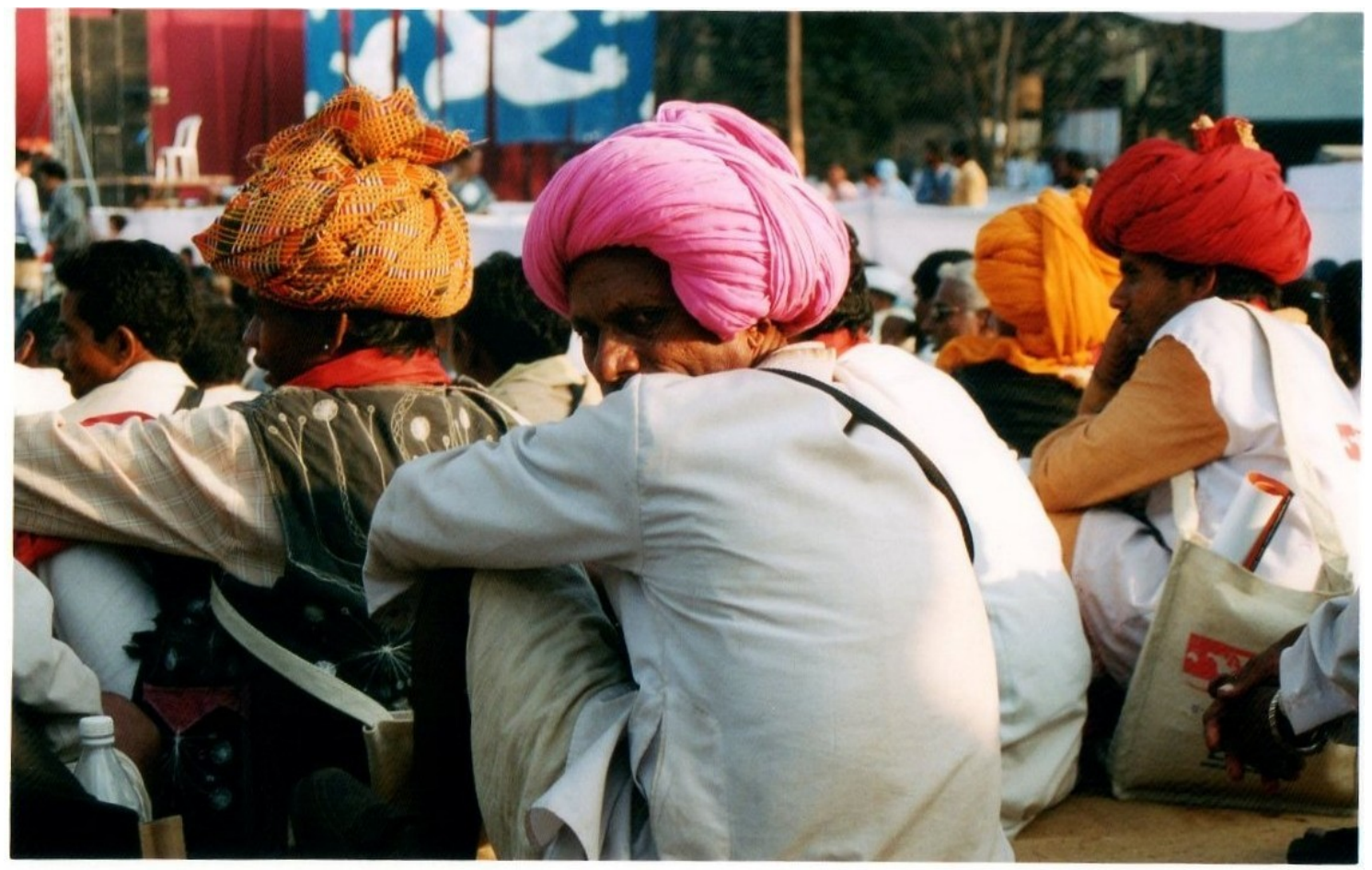

Fórum Social Mundial 2004 - Mumbai, Índia Foto: Ana Roberta V. de Alcântara

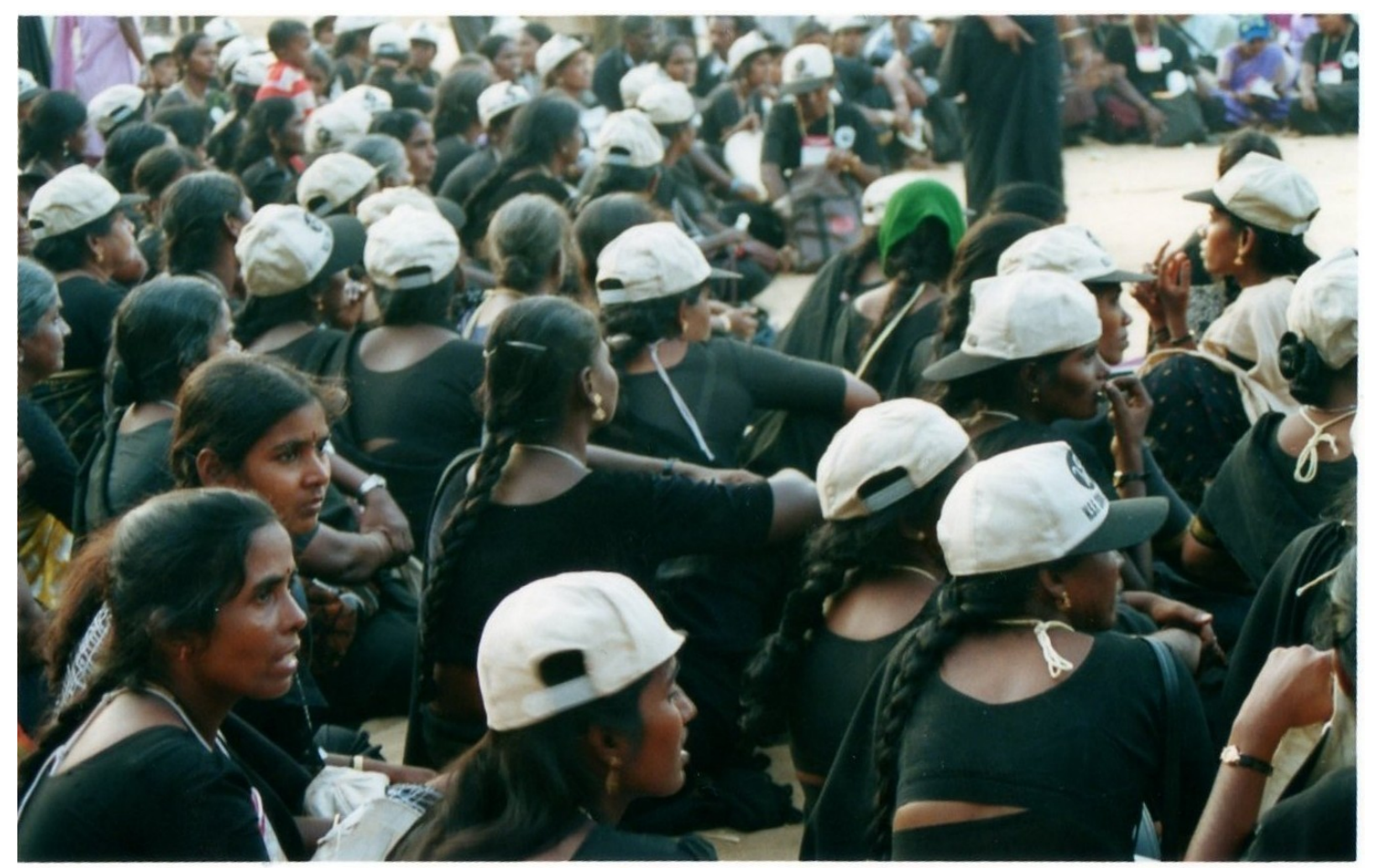

Grupo de mulheres Women in black for peace (Mulheres de preto pela paz) no Fórum Social Mundial 2004 - Mumbai, Índia

Foto: Ana Roberta V. de Alcântara 


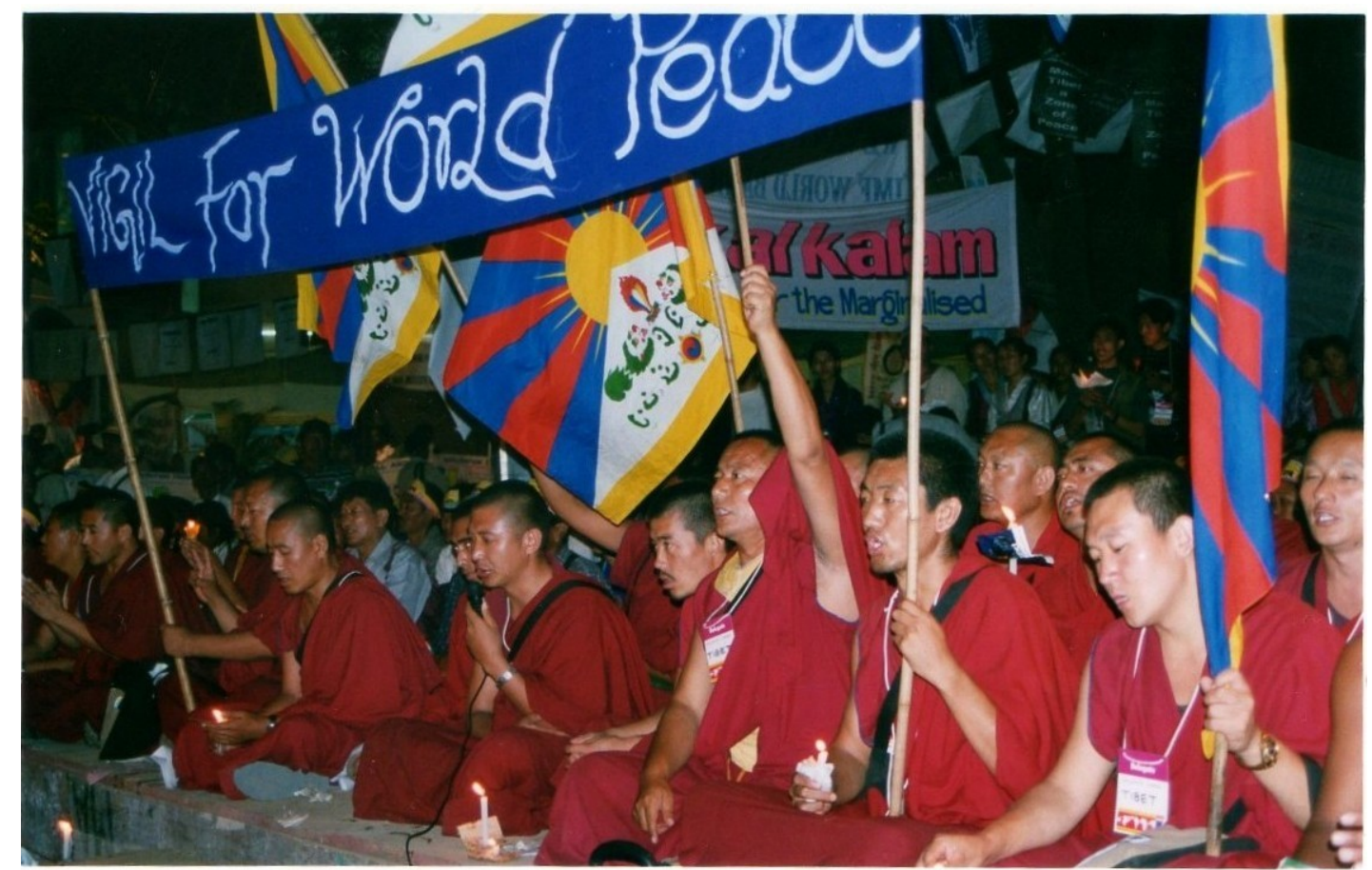

Grupo de tibetanos em ação pela paz no Fórum Social Mundial 2004 - Mumbai, Índia Foto: Ana Roberta V. de Alcântara

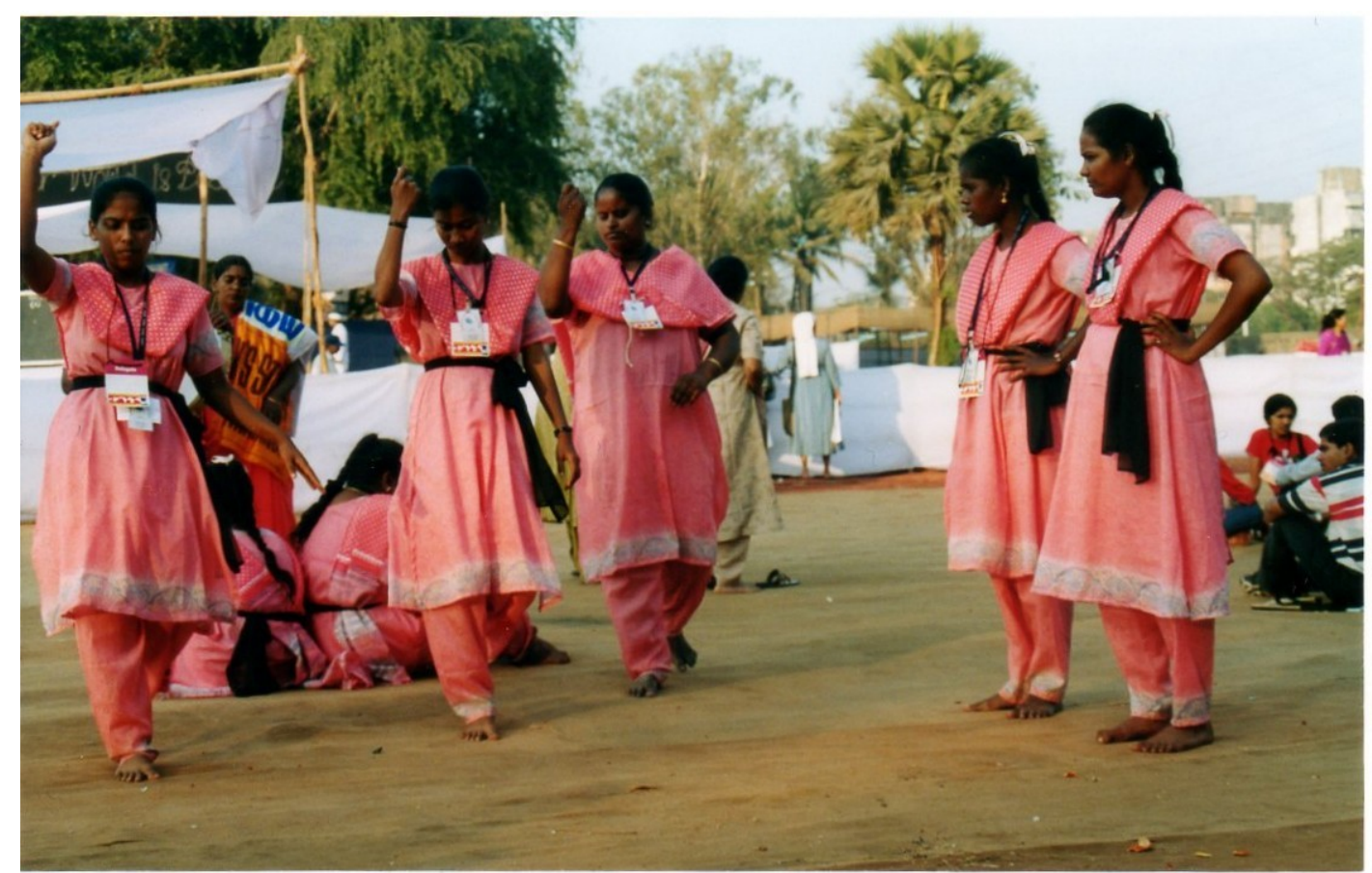

Atividade cultural no Fórum Social Mundial 2004 - Mumbai, Índia Foto: Ana Roberta V. de Alcântara 


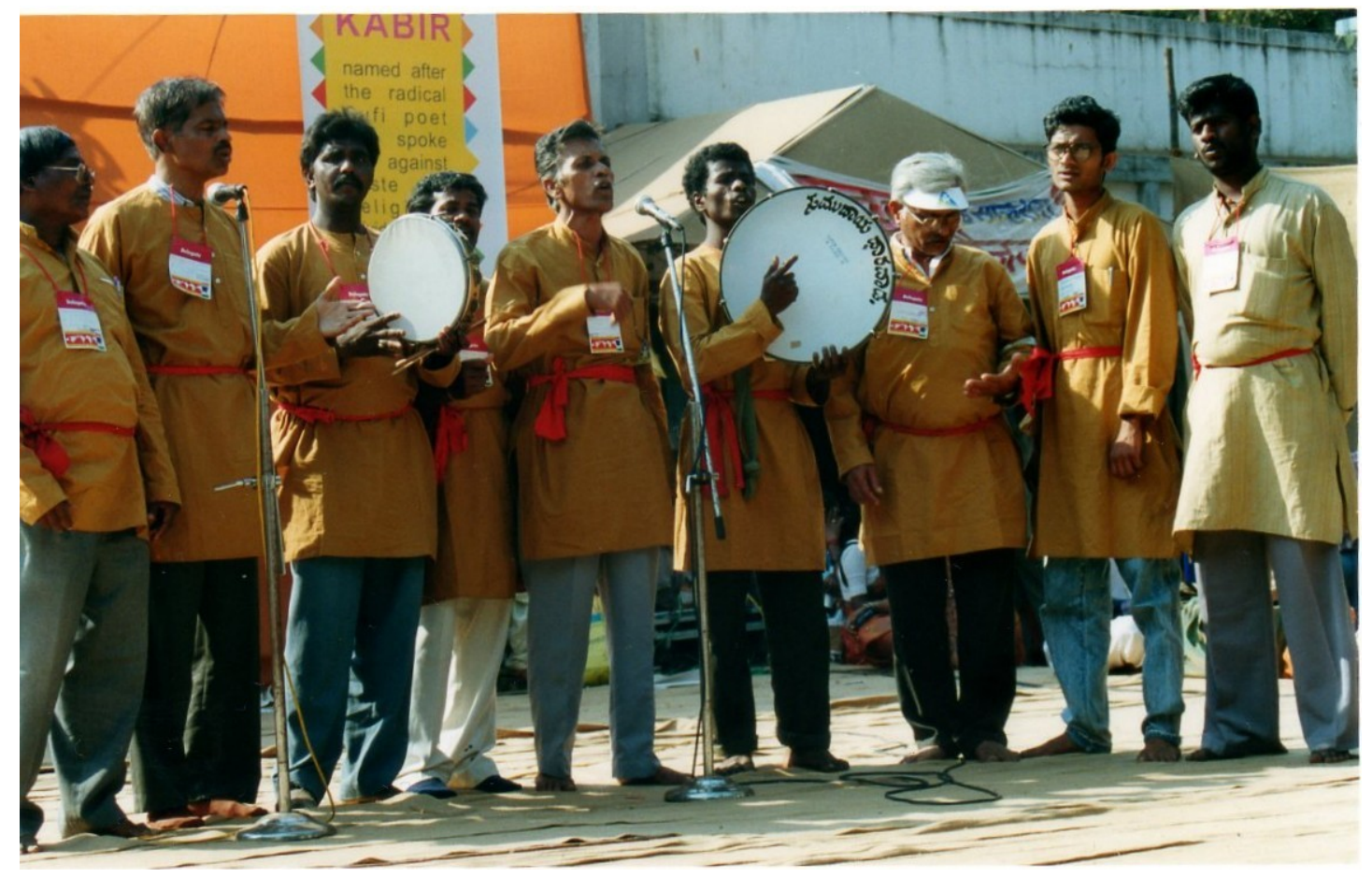

Atividade cultural no Fórum Social Mundial 2004 - Mumbai, Índia Foto: Ana Roberta V. de Alcântara 


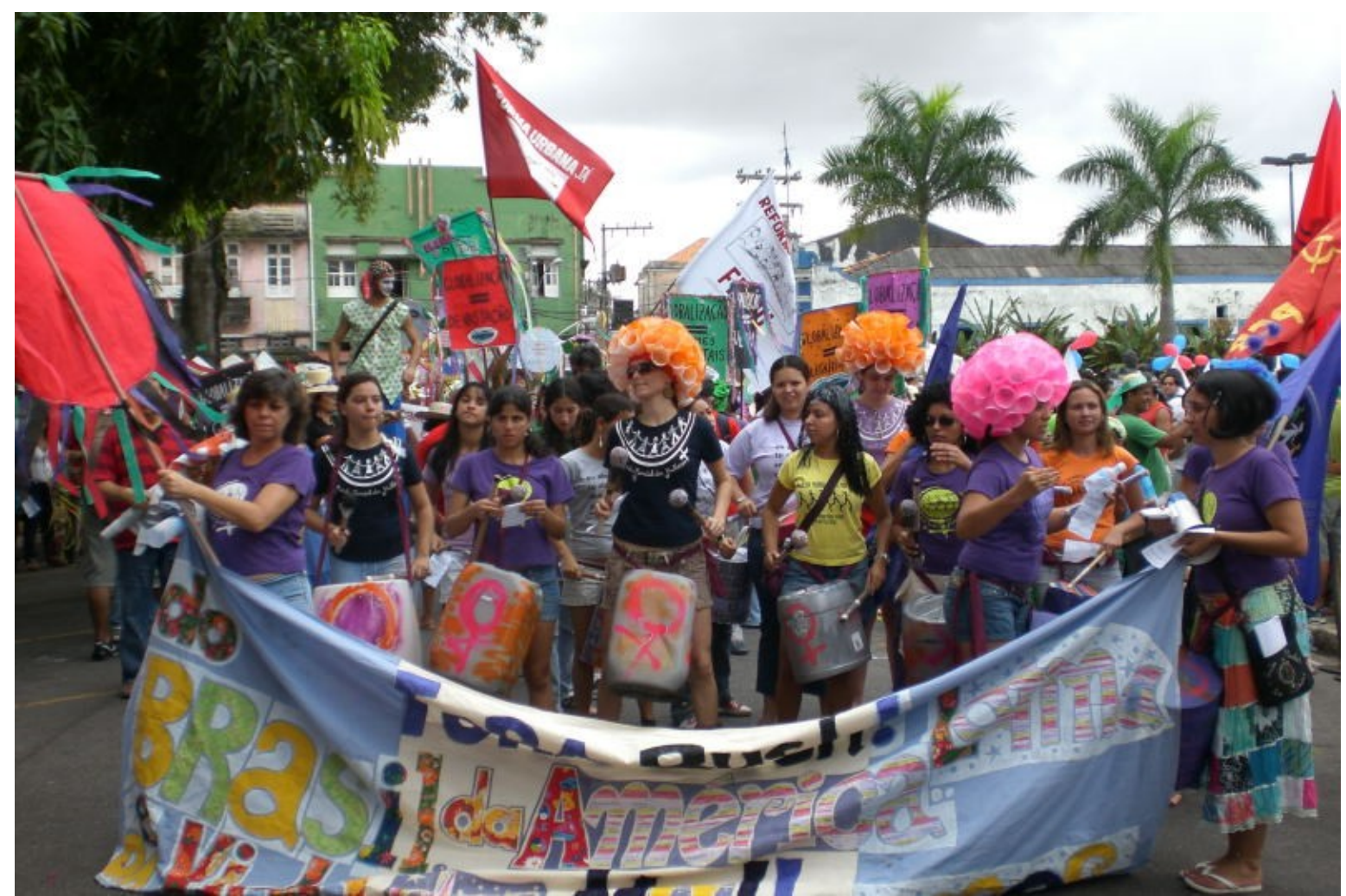

Dia de Ação Global - FSM 2008 - Brasil

Fonte: http://fsainfo.rits.org.br

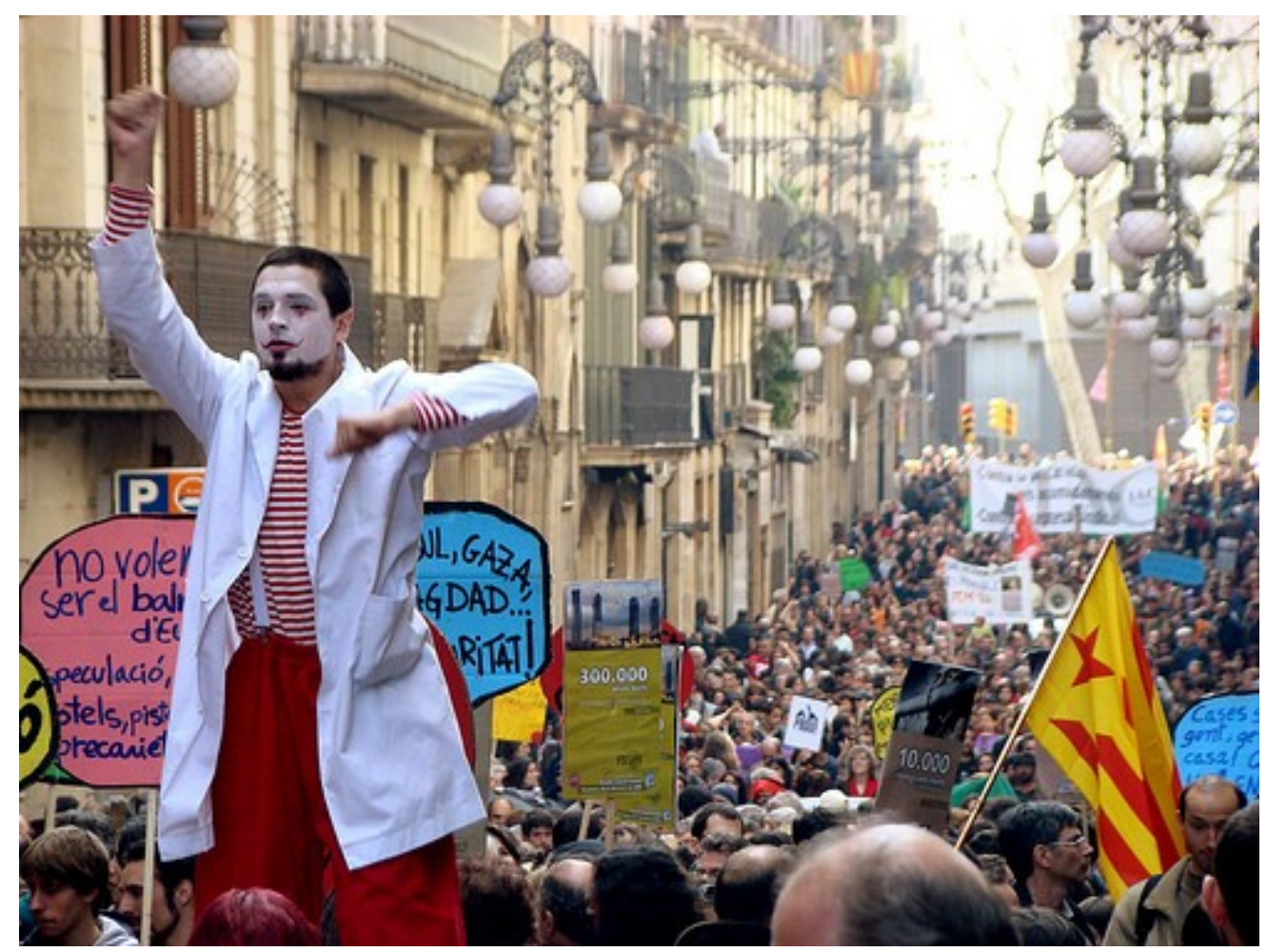

Dia de Ação Global - FSM 2008 - Barcelona, Espanha

Fonte: http://www.ciranda.net 


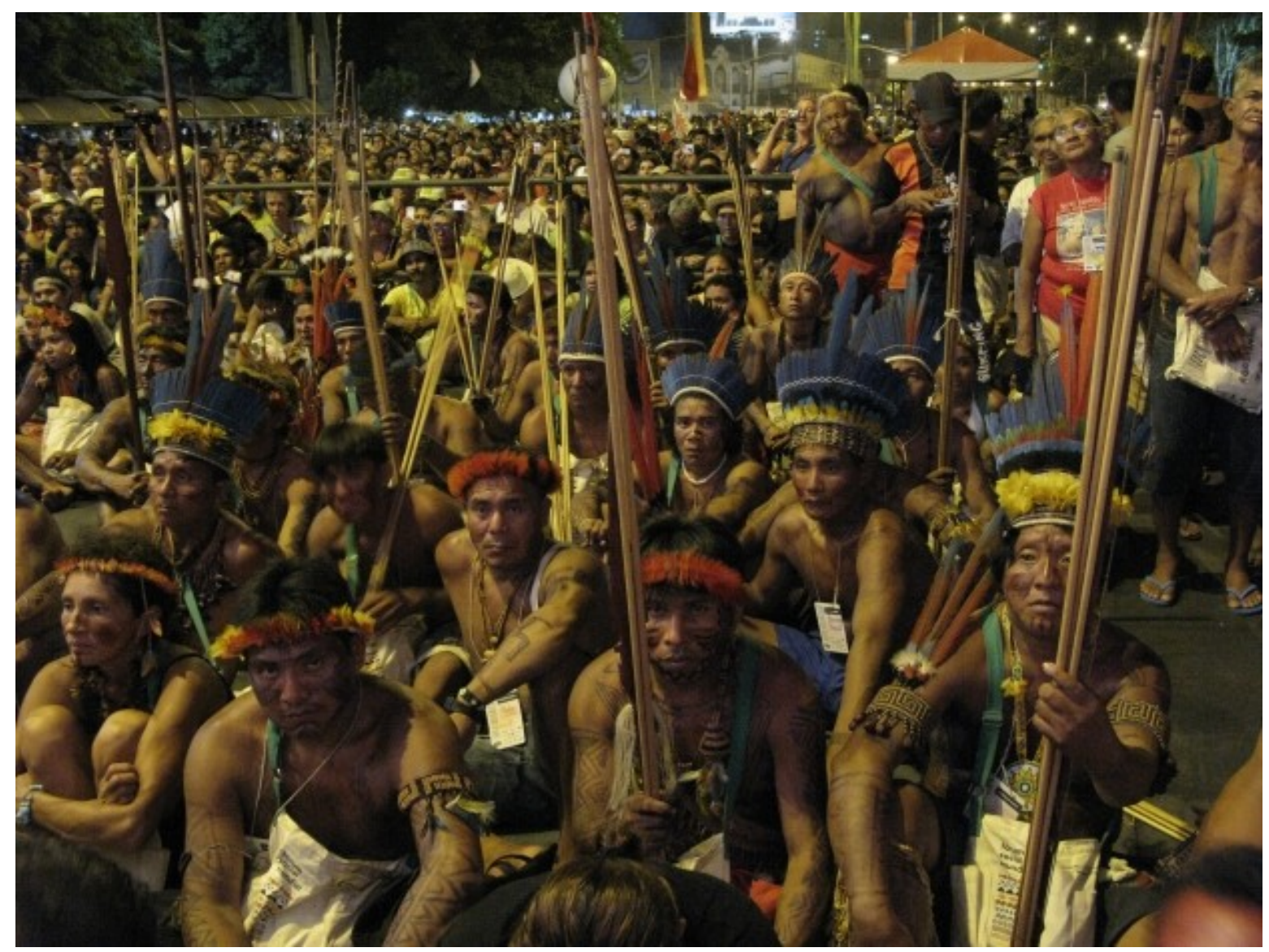

Participação indígena no Fórum Social Mundial 2009 - Belém, Brasil

Foto: Henrique Parra

Fonte: www.midiaindependente.org 


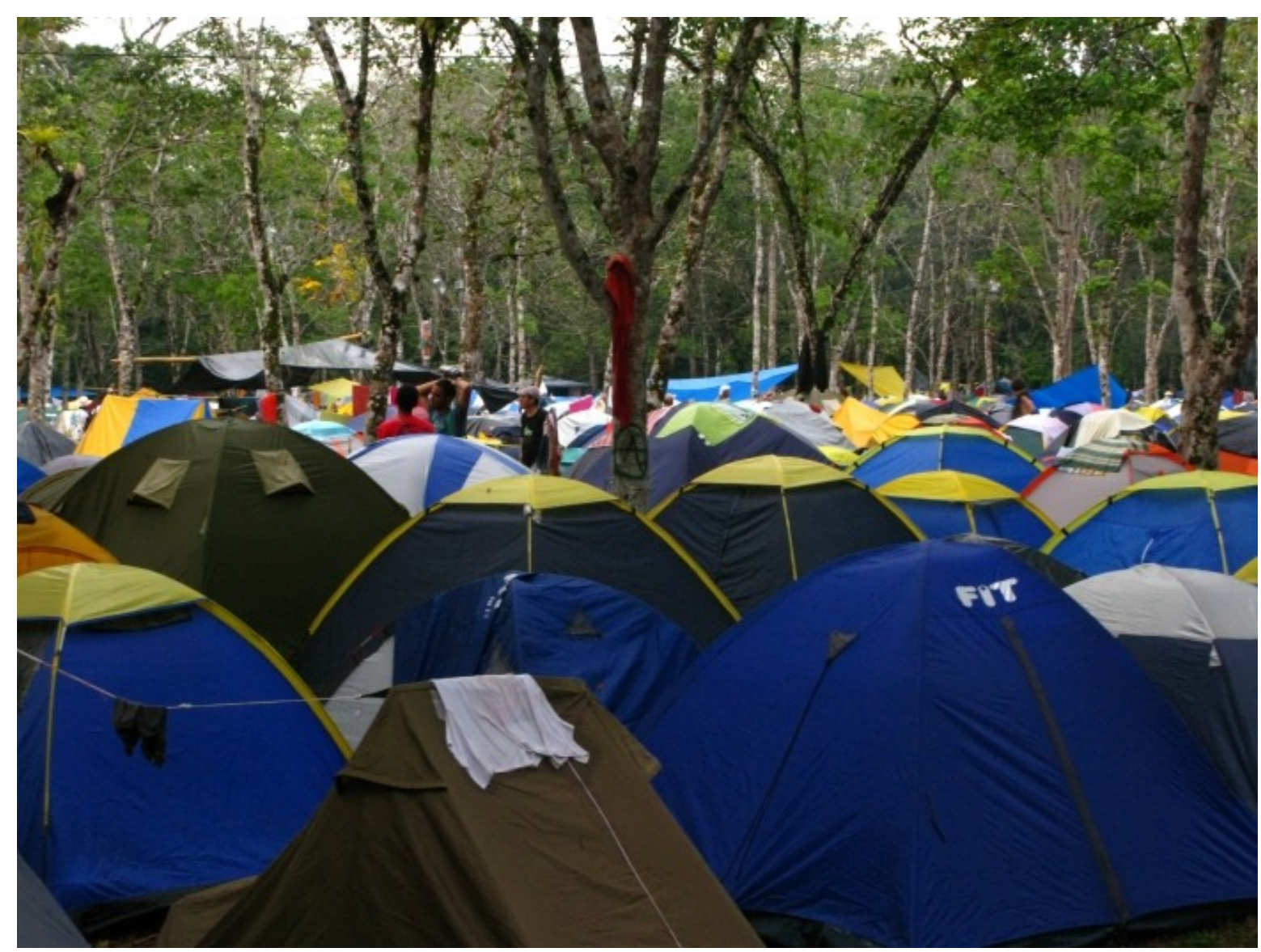

Acampamento da Juventude do Fórum Social Mundial 2009 - Belém, Brasil

Foto: Henrique Parra

Fonte: www.midiaindependente.org 


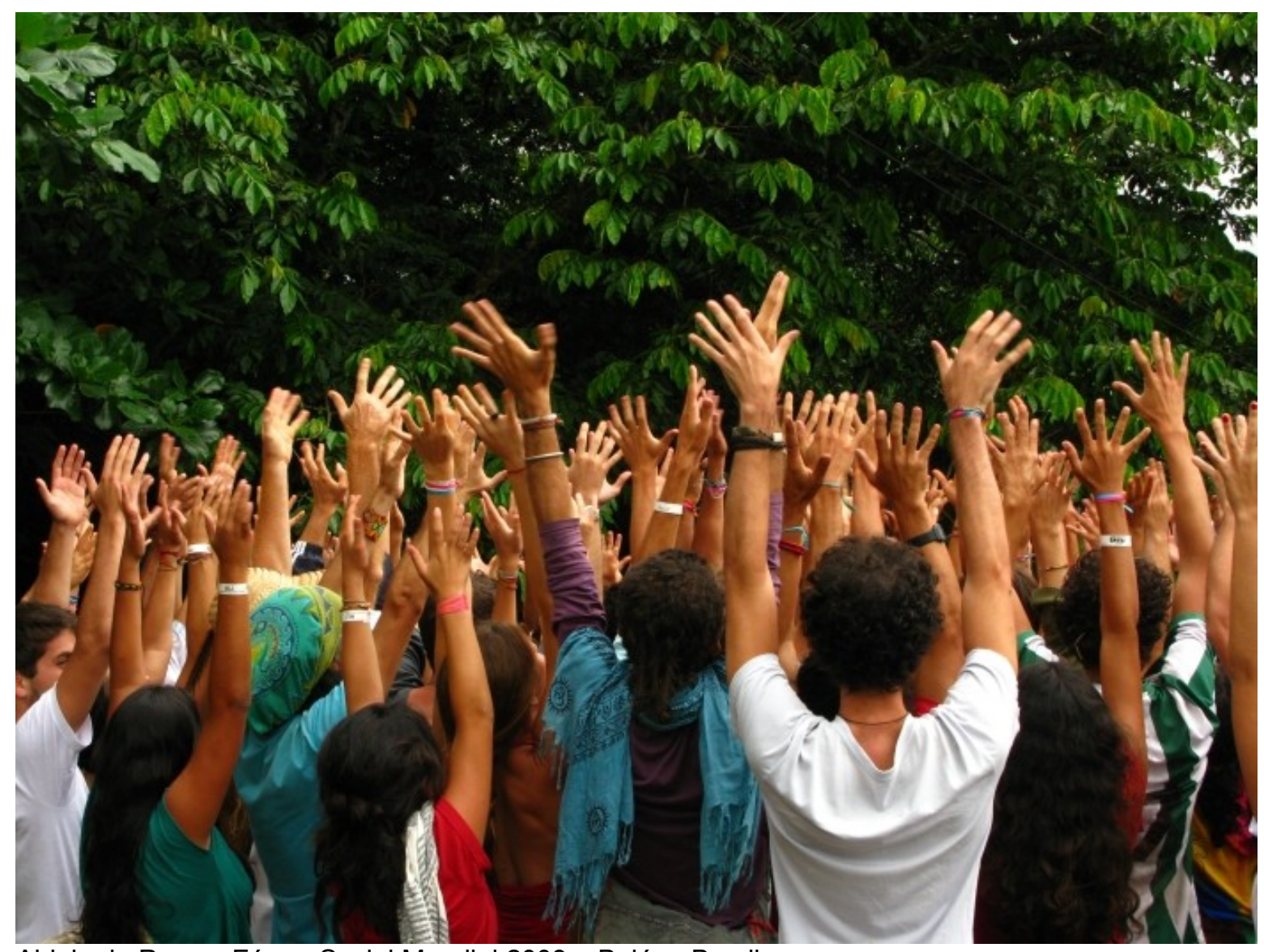

Aldeia da Paz no Fórum Social Mundial 2009 - Belém, Brasil

Foto: Henrique Parra

Fonte: www.midiaindependente.org 